\title{
Plant defense responses induced by phytoseiid predatory mites
}

\author{
TESIS DOCTORAL
}

Joaquín Cruz Miralles

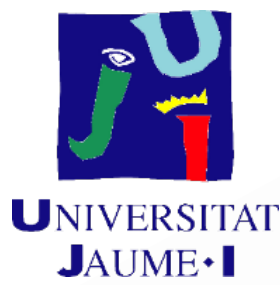

Director: Josep A. Jaques Miret

Castelló de la Plana, junio de 2019 



\section{Programa de Doctorado en Ciencias}

Escuela de Doctorado de la Universitat Jaume I

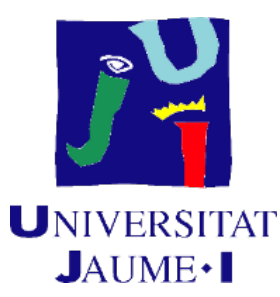

\section{Plant defense responses induced by phytoseiid predatory mites}

Memoria presentada por Joaquín Cruz Miralles para optar al grado de doctor por la Universitat Jaume I

Joaquín Cruz Miralles

Josep A. Jaques Miret

Castelló de la Plana, junio de 2019 



\section{Financiación recibida:}

Este estudio ha sido parcialmente financiado por el MINECO (AGL2014-55616-C3; AGL2015-64990-2R). 



\section{Agradecimientos}

En primer lugar, me gustaría agradecer a mi director de tesis el Doctor Josep A. Jaques Miret, por su apoyo y confianza depositada en mí para poder llegar a cumplir uno de mis sueños profesionales, así como su dedicación y esfuerzo para poder realizar la presente tesis doctoral. En segundo lugar, dar las gracias al doctor Víctor Flors, por ser mi segundo tutor a lo largo de estos cuatro años en muchos de los estudios llevados a cabo. Y en tercer lugar y no por ello menos importante, dar las gracias a Meritxell Pérez Hedo por sus consejos.

En cuanto a mis amigos y compañeros de trabajo, me gustaría resaltar el gran trabajo realizado por Manu Piquer en el cuidado diario de las crías y plantas utilizadas en los ensayos, así como su gran capacidad de adaptar y poner en práctica toda su experiencia y habilidades como técnico de laboratorio. También por todos los buenos consejos que nos ha aportado al grupo (¡gracias MacGyver!). Mi relación con Marc, mi otro compañero de viaje durante estos 4 años comenzó como simples compañeros de trabajo y, a día de hoy, se ha convertido en uno de mis mejores amigos dentro y fuera del trabajo y uno de mis principales apoyos en este tiempo juntos, igracias Marc! Por último, no podía olvidarme de nuestro compañero durante dos años el señor de los latus y de los insectos fósiles y mejor conocido como David, un genio dentro y fuera del laboratorio.

No quiero olvidarme de dar las gracias a la Dra. María Victoria Ibáñez por su ayuda en algunos de los análisis estadísticos del presente trabajo y a Koopert Biological Systems por suministrarnos algunos de los ácaros fitoseidos utilizados en nuestros ensayos de laboratorio.

En cuanto a la familia, agradecer a mis padres todo el esfuerzo que han realizado para que yo, al igual que mi hermano, podamos cumplir el sueño de ser investigadores doctores. A mi hermano mayor Ángel por ser mi amigo y consejero a lo largo de mi vida y por los grandes momentos que hemos pasado juntos con el fútbol y todas nuestras aficiones. A todos mis abuelos y en especial a ella, nuestra segunda madre, ¡mil gracias abuela! A mis amigos de la infancia que son muchos y por no dejarme a alguno no los voy a citar. Y como no, a mi novia Neus Requena Nadal, por ser como es y por saber guiarme en muchos aspectos de mi vida. Además, en este último año ha tenido que aguantarme con un poco más de paciencia de la normal. Te quería recordar, que, aunque una de las cosas más importantes de mi vida profesional sea llegar a ser doctor, jtambién me hace mucha ilusión casarme contigo! ¡Pronto ese segundo sueño compartido se cumplirá! 



\section{Resum}

En la present tesi doctoral s'ha estudiat la capacitat que tenen alguns àcars fitoseids per a induir respostes defensives en la planta. En primer lloc, es van analitzar els mecanismes de defensa que s'activen en els cítrics a partir de la interacció planta-depredador, amb la utilització de dos patrons amb diferent nivell de susceptibilitat per a l'herbívor T. urticae, el més resistent taronger bord (Citrus aurantium), i el més susceptible mandariner Cleòpatra (C. reshni). Es va arribar a la conclusió que els àcars fitoseids poden induir respostes defensives en la planta no sols mitjançant danys produïts per l'alimentació directa (herbivoria) com és el cas d'E. stipulatus, sinó que poden desencadenar-les també mitjançant altres activitats no directament relacionades amb l'alimentació, com podria ser caminar, realitzar la posta, l'excreció, o inclús les seues olors. Mitjançant anàlisis metabòliques, es va observar com la ruta de defensa de l'àcid jasmònic (JA), l'àcid salicílic (SA) i els flavonoides $(C H S)$ poden modificar-se de diferent manera depenent del genotip de la planta i del tipus de dieta que presente l'àcar fitoseid inductor. A continuació, es va estudiar si els volàtils alliberats pels cítrics tenien algun efecte d'atracció o repel·lència per a l'aranya roja, així com per als depredadors. Els experiments van demostrar que els volàtils poden resultar atraients o repel·lents en major o menor mesura depenent del depredador que indueix aquestes respostes. En el cas concret de l' $E$. stipulatus, es va observar com, independentment del genotip de la planta, les plantes infestades pel depredador resultaven atraients per a l'herbívor. Per contra, tots dos patrons de cítric van resultar repel·lents per a l'aranya quan estaven infestats bé per $N$. californicus o per $P$. persimilis. Per a determinar si aquesta repel-lència de l'aranya era per l'olor de la planta o perquè detectava els seus depredadors, vam fer assajos d'elecció sense planta. En aquests resultats, es va observar com els tres fitoseids eren repel-lents per a l'aranya. A més, es van caracteritzar els volàtils alliberats per cadascun dels àcars fitoseids, es va observar com els volàtils majoritaris caracteritzats per al fitoseid especialista d'aranya (P. persimilis) eren monoterpens de planta. Per contra, per al cas dels altres dos fitoseids (E. stipulatus i N. californicus), els compostos orgànics majoritaris van ser del grup dels volàtils de planta "green leaf volatiles" (GLV). L'última part del treball es va basar en estudis de reproducció de cadascun dels tres fitoseids per a tractar de dilucidar si la presa, T. urticae, procedent d'un patró o d'un altre poden afectar el seu desenvolupament normal. Per aquest fet, es va determinar l'aprofitament de la presa en funció de l'hoste. 



\begin{abstract}
The present doctoral thesis is focused on the study of the ability of some phytoseiids mites for inducing defensive plant responses. First, the activation of citrus defense pathways in two rootstocks with different levels of susceptibility for the herbivore T. urticae, the highly resistant sour orange (Citrus aurantium) and the ighly susceptible Cleopatra mandarin (C. reshni), was analysed. The conclusion was that phytoseiid mites can induce plant defensive responses not only through direct feeding (herbivory), as in the case of $E$. stipulatus, but also through other activities not directly related to feeding, as walking, oviposition, excretion, or their own scents. Metabolomic analyses showed that the jasmonic acid (JA), salicylic acid (SA) and flavonoids $(C H S)$ defense pathways were modified in different ways depending on plant genotype and phytoseiid mite diet specialization. Second, attraction and repellence of volatiles released by citrus upon infestation by phytoseiids were studied for both the spider mite and for predators. Experiments showed that the attraction/repellent effect depends on the predator triggering these responses. In the case of E. stipulatus, infested plants were attractive for the herbivore independently of the plant genotype. Contrary, both citrus rootstocks when infested by either $N$. californicus or $P$. persimilis were repellents for $T$. urticae. To determine whether this repellence should be attributed to plant and/or predator odors, we carried out choice tests without plant. In these experiments we observed how the three phytoseiids proved repellent for T. urticae. Furthermore, the volatile blends released by each phytoseiid mite were characterized. That of the specialist predator P. persimilis was mostly made of plant monoterpenes. Interestingly, for the two additional phytoseiids $(E$. stipulatus and $N$. californicus) most of the organic compounds were plant-derived "green leaf volatiles" (GLV). The last part of this study explores the reproduction of the three phytoseiid species when feeding on T. urticae obtained on two different rootstocks. The profitability of the prey depending on the host was determined.
\end{abstract}





\section{Resumen}

En la presente tesis doctoral se ha estudiado la capacidad que tienen algunos ácaros fitoseidos para inducir respuestas defensivas en la planta. En primer lugar, se analizaron los mecanismos de defensa que se activan en los cítricos a partir de la interacción plantadepredador, utilizando dos patrones con distinto nivel de susceptibilidad para el herbívoro T. urticae, el más resistente naranjo amargo (Citrus aurantium), y el más susceptible mandarino Cleopatra (C. reshni). Se llegó a la conclusión de que los ácaros fitoseidos pueden inducir respuestas defensivas en la planta no sólo mediante daños producidos por la alimentación directa (herbivoría), como es el caso de E. stipulatus, si no que pueden desencadenarlas también mediante otras actividades no alimenticias, como podrían ser el caminar, realizar la puesta, la excreción, o incluso sus propios olores. Mediante análisis metabolómicos se observó como la ruta de defensa del ácido jasmónico (JA), el ácido salicílico (SA) y los flavonoides $(C H S)$ pueden modificarse de distinta manera dependiendo del genotipo de la planta y del tipo de dieta que presente el ácaro fitoseido inductor. A continuación, se estudió si los volátiles liberados por los cítricos tenían algún efecto de atracción o repelencia para la araña roja, así como para los depredadores. Los experimentos demostraron que los volátiles pueden resultar atrayentes o repelentes en mayor o menor medida dependiendo del depredador que induce dichas respuestas. En el caso concreto del E. stipulatus, se observó cómo independientemente del genotipo de la planta, las plantas infestadas por el depredador resultaban atrayentes para el herbívoro. Por el contrario, ambos patrones de cítrico resultaron repelentes para la araña cuando estaban infestados o bien por N. californicus o por P. persimilis. Para determinar si esta repelencia era por los olores de la planta o porque detectaba a sus depredadores, hicimos ensayos de elección sin planta. En estos ensayos se observó cómo los tres fitoseidos eran repelentes para la araña. Además, se caracterizaron los volátiles liberados por cada uno de los ácaros fitoseidos, observando como los volátiles mayoritarios caracterizados para el fitoseido especialista de araña $P$. persimilis eran monoterpenos de planta. Por el contrario, para el caso de los otros dos fitoseidos (E. stipulatus y N. californicus) los compuestos orgánicos mayoritarios fueron del grupo de los volátiles de planta "green leaf volátiles" (GLV). En la última parte del trabajo se estudió la reproducción de los tres fitoseidos para dilucidar si las arañas procedentes de un patrón u otro pueden afectarles en su desarrollo normal. Para ello, se determinó el aprovechamiento de la presa en función del huésped. 



\section{Índice}

INTRODUCCIÓN.........................................................................................................1

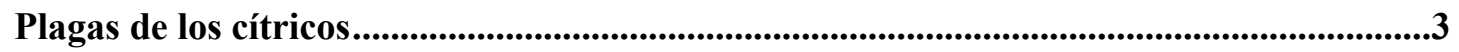

La gestión integrada de plagas en cítricos ..........................................................................................3

Tetranychus urticae ......................................................................................................................4

Alternativas al control químico: control biológico ...........................................................................5

Principales ácaros depredadores de araña .....................................................................6

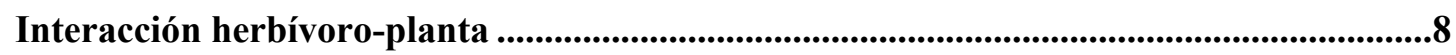

Interacción omnívoro-planta........................................................................................................9

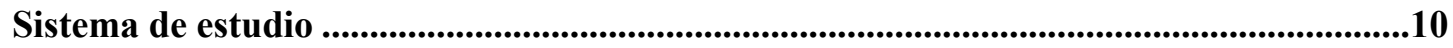

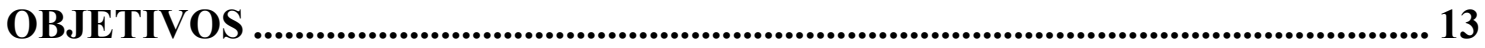

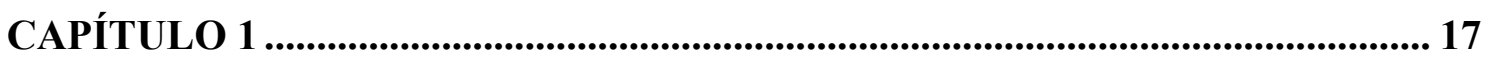

1.1 Introduction .......................................................................................................................................21

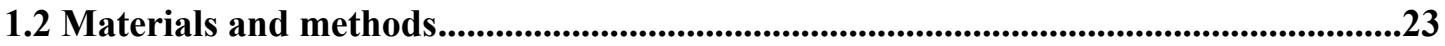

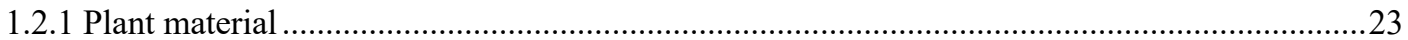

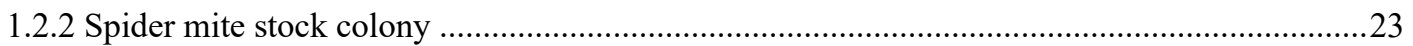

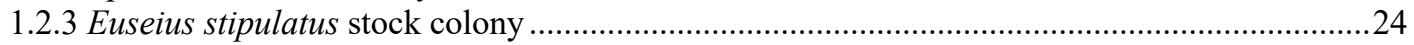

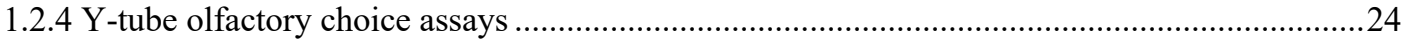

1.2.5 Quantitative real-time reverse transcription-polymerase chain reaction (qRT-PCR) analysis..25

1.2.6 Collection of headspace volatiles in plants occupied by E. stipulatus ....................................26

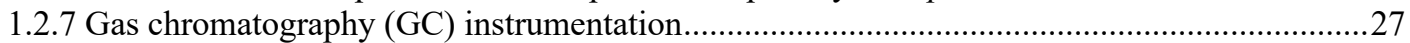

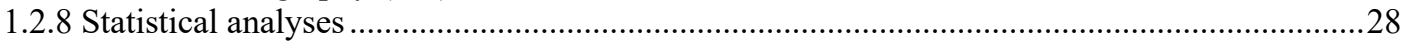

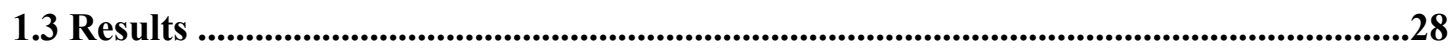

1.3.1 E. stipulatus-occupied citrus plants modify the behavior of conspecifics and also of the

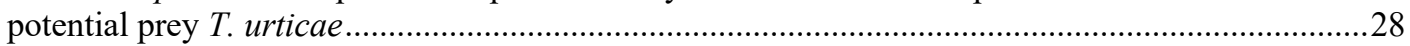
1.3.2 The generalist predator E. stipulatus triggers defensive responses in sour orange and Cleopatra

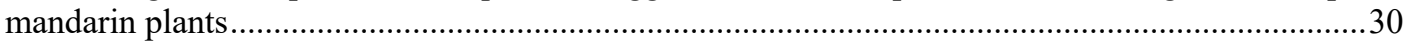

1.3.3 The generalist predator E. stipulatus triggers the production of volatiles (HIPVs) in sour

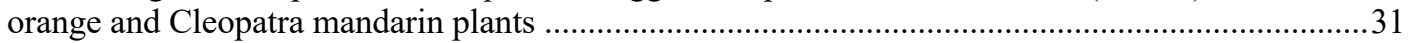

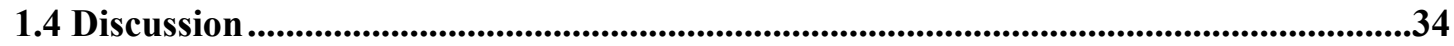

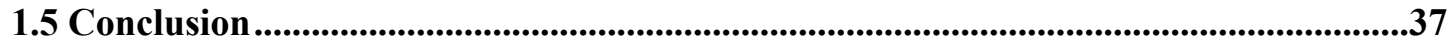

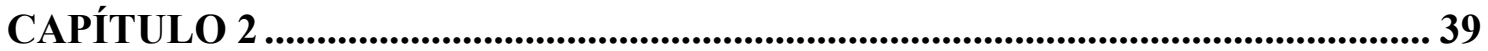

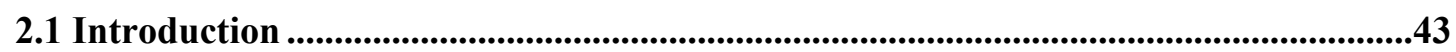

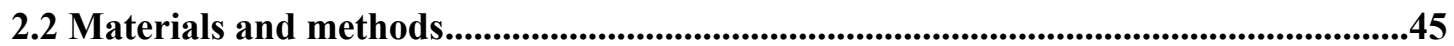

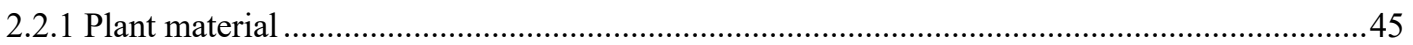

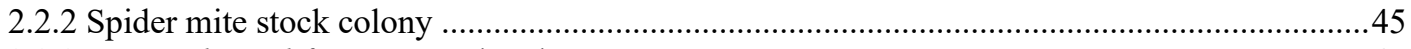

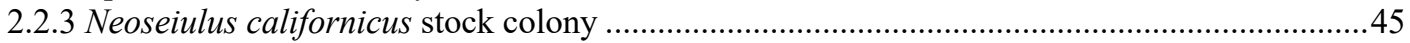

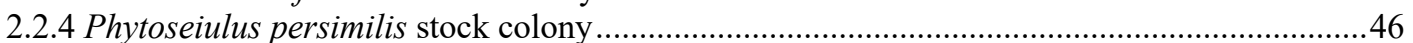

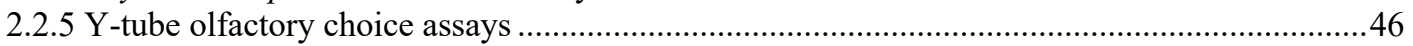

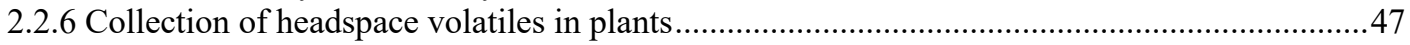

2.2.7 Gas chromatography (GC) instrumentation........................................................................

2.2.8 Quantitative real-time reverse transcription-polymerase chain reaction (qRT- PCR) analysis in

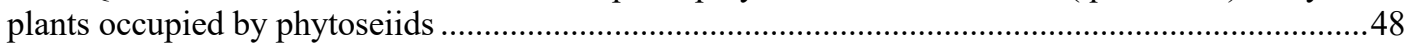

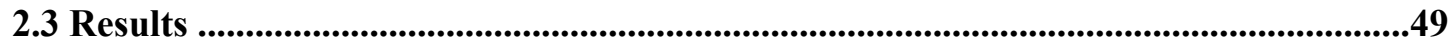
2.3.1 The presence of either $N$. californicus or P. persimilis in citrus plants modifies the behavior of conspecifics and also of their potential prey $T$. urticae 
2.3.2 The omnivorous predator $N$. californicus but not the strict entomophagous $P$. persimilis triggers the production of volatiles in sour orange and Cleopatra mandarin plants

2.3.3 The omnivorous predator $N$. californicus triggers defensive responses in sour orange and

Cleopatra mandarin plants .....

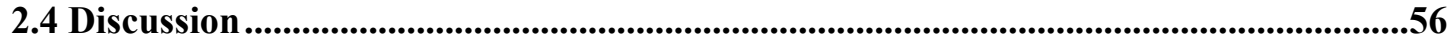

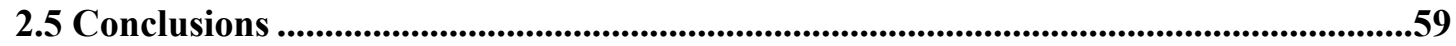

CAPÍTULO 3 [....................................................................................................... 61

3.1 Introduction .......................................................................................................65

3.2 Materials and methods...........................................................................................68

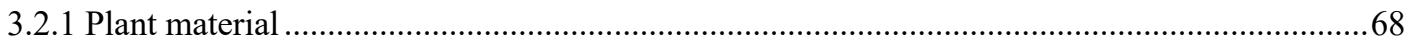

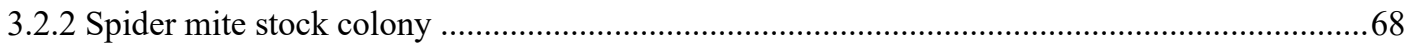

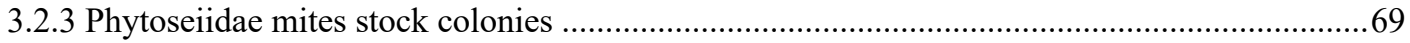

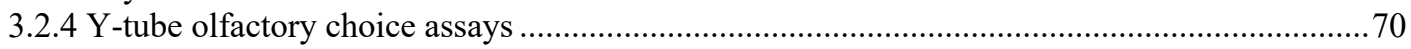

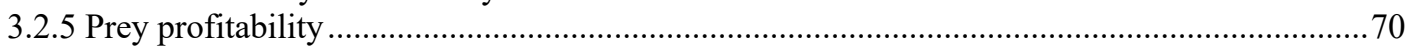

3.2.6 Characterization of phytoseiid associated volatiles ........................................................ 71

3.3 Results ........................................................................................................................72

3.3.1 The presence of IG competitors can modify the response of phytoseiids to citrus odors ..........72

3.3.2 The host plant where prey feeds affects its profitability for phytoseiids .................................76

3.3.3 GLVs are widely present in phytoseiid scents but monoterpenes are not associated to $E$.

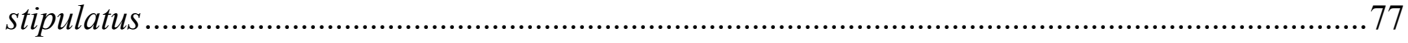

3.4 Discussion ....................................................................................................................79

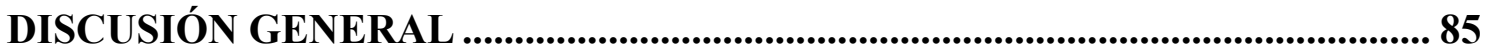

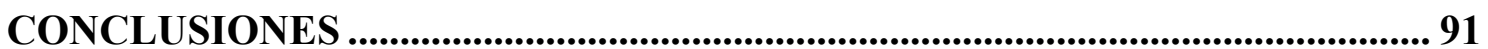

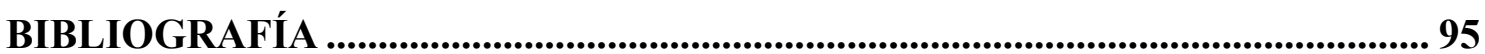


INTRODUCCIÓN 



\section{Plagas de los cítricos}

De entre el centenar de especies fitófagas que podemos encontrar en los huertos de cítricos de la Península Ibérica, sólo unas 15 alcanzan la categoría de especie plaga. Estas especies se pueden agrupar como fitófagos secundarios, plagas ocasionales o clave, en función del efecto que ejercen sobre ellos los factores naturales de regulación, entre los que destacan sus principales enemigos naturales (Urbaneja y Jacas, 2008). A pesar de que la mayoría de especies plaga de los cítricos presentan un buen control biológico por parte de sus enemigos naturales (Jacas y Urbaneja, 2010), existen otras en cuyo caso el control biológico no es satisfactorio y las densidades del fitófago superan el umbral económico de daños (UED), pasando a formar parte de las plagas clave de los cítricos (Urbaneja y Jacas, 2008). Entre estas últimas, en los cítricos valencianos encontramos al piojo rojo de Californica, Aonidiella aurantii (Maskell) (Hemiptera: Diaspididae), a los pulgones Aphis spiraecola Patch y A. gossypii Glover (Hemiptera: Aphididae), a la mosca mediterránea de la fruta Ceratitis capitata (Wiedemann) (Díptera: Tephritidae) y a la araña roja Tetranychus urticae Koch (Prostigmata: Tetranychidae), siendo esta última la plaga clave sobre la que se centra la presente tesis doctoral.

\section{La gestión integrada de plagas en cítricos}

La Gestión Integrada de Plagas (GIP) se define como la combinación de todos los métodos de control disponibles, tales como métodos bilógicos, biotecnológicos, químicos y culturales incluida la no intervención, tratando de reducir al mínimo imprescindible el uso de productos fitosanitarios. Su objetivo principal es evitar que la población de la especie plaga supere el umbral económico de daños (UED) (Tena et al., 2011).

En las últimas décadas, en los países desarrollados se están implementando modernos sistemas productivos englobados dentro de las prácticas agrícolas sostenibles, caracterizadas por diferentes métodos de control que respetan al máximo el medio ambiente y la biodiversidad (Wijnands y Kroonen-Backbier, 1993). La Organización Internacional para la Lucha Biológica (OILB) fue pionera dentro de Europa para establecer estrategias de tipo integrado. En 2009 se publicó la directiva sobre la sostenibilidad en el uso de plaguicidas, en la cual se establecieron unos principios básicos para poner en práctica el uso de la GIP como política de la Unión Europea (OJEU, 2009). En la actualidad, y después de la entrada en vigor en el año 2014 de la Directiva 
2009/128/CE del Parlamento Europeo y del Consejo de 21 de octubre de 2009 los principios de la GIP son obligatorios para todos los productores europeos.

\section{Tetranychus urticae}

La araña roja, T. urticae (Figura I.1), se considera el tetraníquido más perjudicial a nivel mundial (Helle y Sabelis 1985), ya que es una especie polífaga y cosmopolita con capacidad para desarrollarse sobre más de 1000 huéspedes distintos de los que unos 150 tienen importancia económica (Attia et al., 2013). En cítricos afecta principalmente a la mandarina clementina (Citrus clementina Hort. ex Tan.) y limoneros (Citrus limon (L.) Burm f.) (Abad-Moyano et al., 2008) pudiendo causar daños directos en fruto (PascualRuiz et al., 2014). Sus colonias se desarrollan sobre el envés de las hojas, donde quedan protegidas gracias a la telaraña que producen, facilitándoles la supervivencia en climas secos (Aucejo y Jacas, 2005). Además, la telaraña las protege de sus depredadores (Sabelis y Bakker, 1992) así como de algunos tratamientos acaricidas. Gracias al gran potencial biótico que presenta este fitófago, en condiciones óptimas (elevadas temperaturas y bajas humedades relativas), pueden llegar a alcanzar elevadas densidades poblacionales ocasionando importantes daños económicos (Pascual-Ruiz et al., 2014).
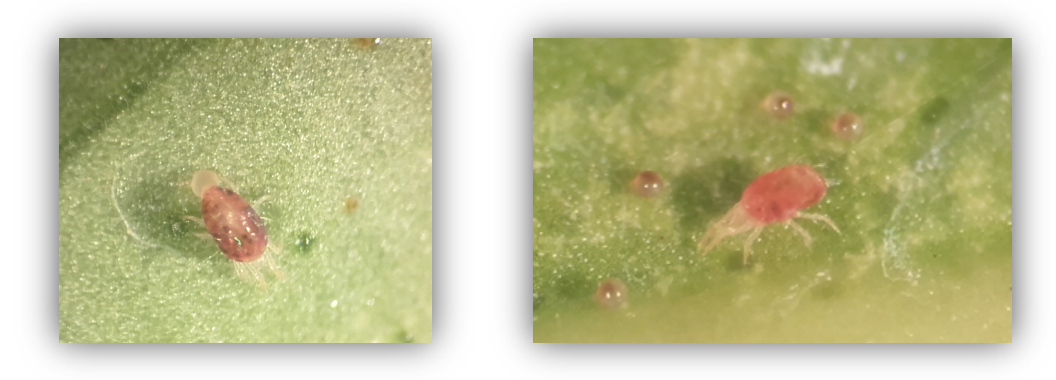

Figura I.1 Hembra adulta de T. urticae realizando la puesta (izquierda) y nido con huevos rodeando a la hembra adulta (derecha)

En clementino, este ácaro herbívoro, puede ocasionar manchas cloróticas sobre las hojas además de abombamiento sobre el haz (Figura I.2), siendo en la época estival el periodo donde se pueden producir graves defoliaciones del árbol (Aucejo y Jacas, 2005). Pero el daño más importante a nivel comercial son las manchas en los frutos que deprecian su valor comercial para consumo en fresco (Pascual-Ruiz et al., 2014). 


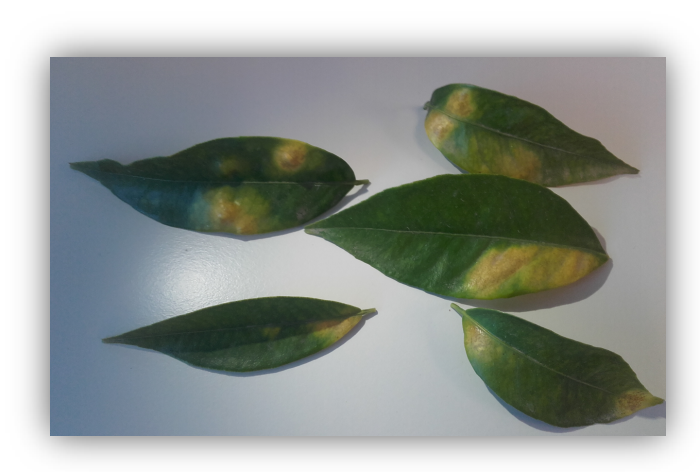

Figura I.2 Manchas cloróticas en hoja de cítrico

\section{Alternativas al control químico: control biológico}

En las últimas décadas, el principal método de control de $T$. urticae ha sido el control químico mediante acaricidas (Martínez-Ferrer et al., 2006; Pascual-Ruiz et al., 2014). Debido a un uso desmesurado de los productos fitosanitarios, las poblaciones de araña se han hecho resistentes a diferentes sustancias activas (Van Leeuwen et al., 2008), pudiendo decir que el control químico, hoy en día, es una herramienta poco eficaz para combatir esta plaga. Además, el mal uso de estos acaricidas ha ocasionado la pérdida de la fauna útil asociada a T. urticae (Urbaneja et al., 2008; Sá Argolo et al., 2013, 2014).

En las últimas décadas, se han desarrollado otros métodos con más éxito dentro de la GIP en cultivos de cítricos, en los cuales se han combinado las aplicaciones de plaguicidas selectivos junto a la conservación y/o suelta de ácaros depredadores para mejorar el control biológico de la araña (Urbaneja y Jacas, 2008). Por todo esto, el presente trabajo se ha centrado en tres de los ácaros fitoseidos más abundantes en huertos de cítricos, que pueden contribuir a mejorar la sostenibilidad del control de la araña roja. 


\section{Principales ácaros depredadores de araña}

Existe un variado complejo de enemigos naturales asociados a T. urticae pertenecientes a distintos grupos taxonómicos, donde se puede destacar al grupo de los ácaros depredadores de la familia Phytoseiidae (Mesostigmata) (Aguilar-Fenollosa et al., 2012). De entre todos los ácaros depredadores, tres son los más comunes en la citricultura española: Euseius stipulatus (Athias-Henriot), Neoseiulus californicus (McGregor) y Phytoseiulus persimilis (Athias-Henriot) (Abad-Moyano et al., 2009a; Aguilar-Fenollosa et al., 2011a). Estos depredadores tienen diferente grado de especialización en sus dietas, desde depredadores generalistas con dietas variadas como es el caso del omnívoro $E$. stipulatus, el cual se alimentan tanto de derivados animales como de plantas, hasta depredadores específicos de arañas del género Tetranychus spp., como es el caso de $P$. persimilis. El depredador especialista en tetraníquidos $N$. californicus presenta una dieta intermedia entre estos dos ácaros, pudiéndose alimentar tanto de presas como de derivados de plantas (polen) (McMurtry et al., 2013).

Euseius stipulatus es un depredador generalista, omnívoro y palinófago (McMurtry y Croft, 2013). Es el más abundante en la citricultura española (sobre el $70 \%$ del total de fitoseidos), tanto en los árboles como en la flora adventicia asociada, independientemente del sistema de gestión y de la variedad cultivada (Abad-Moyano et al., 2009a; AguilarFenollosa et al., 2011a, b; Vela et al., 2017). Se alimenta de polen, ácaros fitófagos, pequeños insectos, y melaza (Pérez-Sayas et al., 2015). Este ácaro zoofitófago, aunque especializado en polen, es capaz de alimentarse de T. urticae (Pina et al., 2012). Además, se ha descrito que el género Euseius De Leon, al que pertenece este ácaro, presenta los quelíceros adaptados para picar a la planta y complementar su nutrición alimentándose de ella (Adar et al., 2012, 2015). Según los estudios de Adar et al. (2012) las picaduras en planta por parte del género Euseius, pueden ser específicas del cultivar. Algunos autores (Abad-Moyano et al., 2010a, b) consideran a este depredador el más fuerte respecto a otros, lo cual se ha relacionado con su elevada abundancia en campo y con el deficiente control de T. urticae (Aguilar-Fenollosa et al., 2011a). Sin embargo, otros autores piensan lo contrario (Guzmán et al., 2016; Urbaneja-Bernat et al., 2019). 

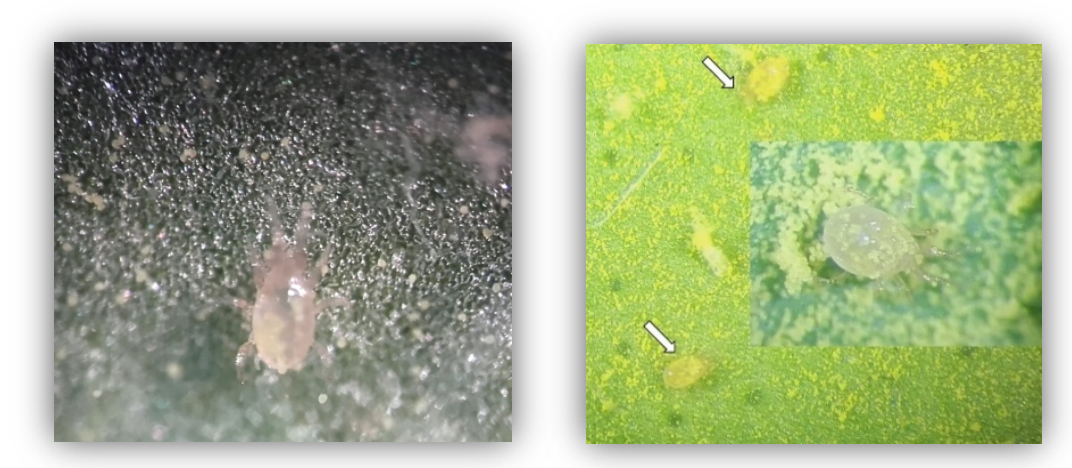

Figura I.3 Hembra de E. stipulatus sobre hoja de judía con polen (izquierda) y hembras de $E$. stipulatus sobre hoja de cítrico con polen (derecha)

Neoseiulus californicus es un depredador polífago con preferencia por los tetraníquidos (McMurtry y Croft, 1997), pudiéndose alimentar también de polen (Escudero y Ferragut, 1996) y pequeños insectos (Easterbrook et al., 2001). Este ácaro depredador omnívoro, no consigue aumentar mucho sus poblaciones cuando utiliza el polen como único recurso (Pina et al., 2012) y además se sabe a través de estudios de la morfología de sus quelíceros que no está adaptado para alimentarse de las plantas (Adar et al., 2012). A pesar de que se utiliza en agricultura como agente de control biológico de la araña roja, el control natural que ejerce sobre $T$. urticae en árboles de mandarina clementina es insuficiente (Abad-Moyano et al., 2009a).

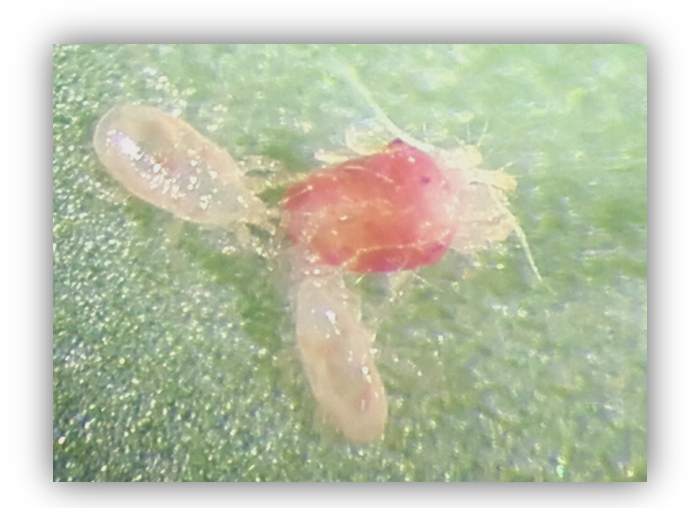

Figura I.4 Hembras de N. californicus alimentándose de una misma presa (T. urticae)

Phytoseiulus persimilis se considera como el depredador por excelencia de T. urticae (Abad-Moyano et al., 2009a; Aguilar-Fenollosa et al., 2011b), al ser un entomófago específico de esta especie (Badii y McMurtry, 1984). Gracias a algunas características tales como el elevado potencial del aumento de su población (Zhang, 1995), corto periodo de desarrollo (Sabelis y Janssen, 1994) y una elevada tasa de puesta, lo hacen ser un 
candidato perfecto para control biológico tanto aumentativo como por conservación (Aguilar-Fenollosa et al., 2011a,b,c). El problema más grande que encontramos en este depredador es que no persiste en el campo cuando su presa desaparece, ya que a diferencia de los otros dos fitoseidos, $P$. persimilis no se reproduce con alimentos alternativos.

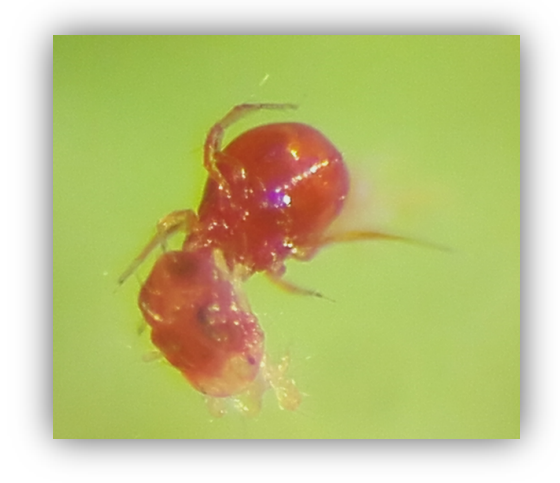

Figura I.5 Hembra adulta de $P$. persimilis alimentándose de su presa $T$. urticae

\section{Interacción herbívoro-planta}

Las plantas han desarrollado distintos sistemas defensivos directos e indirectos frente a herbívoros. Dichos mecanismos de defensa pueden estar presentes en las plantas de forma constitutiva o pueden activarse a partir de distintos mecanismos de inducción por herbivoría. La defensa directa constitutiva es la que está siempre presente en la planta, mientras que la directa inducida implica la producción de distintas señales moleculares, lo que da lugar a la biosíntesis de compuestos específicos que resultan tóxicos para los herbívoros (Kant et al., 2015). Estos compuestos reducen las poblaciones de herbívoros, ya que pueden reducir su crecimiento, supervivencia y reproducción (Howe y Jander, 2008; Kant et al., 2015).

La defensa inducida puede ser local, expresándose en el lugar donde se produce el daño, o sistémica, cuando la señal defensiva se transmite a distintas partes de la planta. Dicha regulación defensiva se lleva a cabo gracias a las fitohormonas (Pieterse et al., 2009). Las principales hormonas presentes en la defensa de las plantas son el ácido jasmónico (JA), el ácido salicílico (SA) y el etileno (Erb et al., 2012; Pieterse et al., 2012). RodríguezSaona et al. (2010) demostraron que la defensa de las plantas puede diferir cualitativa y cuantitativamente dependiendo de la especie herbívora que esté atacando. Además, puede variar según el tiempo transcurrido desde el ataque (Kant et al., 2004). 
Pero las plantas no solo pueden reducir el daño causado por herbivoría de forma directa, síno también indirectamente mediante la atracción de los denominados enemigos naturales, por lo que a este mecanismo se le conoce como defensa indirecta (Dicke y Sabelis, 1989; Karban y Baldwin, 1997; Sabelis et al., 2001). Las plantas han desarrollado distintos mecanismos para favorecer la presencia de estos enemigos naturales, como puede ser la producción de alimento alternativo, como néctar y otras secreciones azucaradas (Heil et al., 2001; Wäckers, 2001). Además, algunas plantas han desarrollado refugios, los 'domatia', donde estos enemigos naturales pueden estar más protegidos y como consecuencia mejorar su supervivencia (Walter, 1996). Otro aspecto muy importante relacionado con la defensa de las plantas por herbivoría, es la liberación de mezclas de compuestos orgánicos las cuales pueden resultar repelentes para los herbívoros (Agut et al., 2015) y atrayentes para los enemigos naturales (Sabelis et al., 1999; Dicke y van Loon, 2000; Bouagga et al., 2018). Estas mezclas volátiles difieren cualitativa y cuantitativamente dependiendo de la especie de planta (van den Boom et al., 2004), de la especie de herbívoro que se esté alimentando de la planta (Birkett et al., 2003) y del periodo en el que los herbívoros se están alimentando de las plantas (Turlings et al., 1998; Kant et al., 2004). Además, estos compuestos pueden variar también por otros factores bióticos o abióticos (Dicke y van Loon, 2000).

\section{Interacción omnívoro-planta}

En los últimos años se ha estudiado con detalle la importancia de un grupo muy concreto de depredadores, los denominados zoofitófagos, como principales agentes de control biológico de algunas especies plaga (Coll y Guershon, 2002; Pérez-Hedo et al., 2015; Naselli et al., 2016; Bouagga et al., 2018; Zhang et al., 2018). Los depredadores omnívoros son muy comunes en la naturaleza y contribuyen de forma significativa a mantener la estabilidad de las redes tróficas (Fagan, 1997). Curiosamente muchos enemigos naturales (depredadores) son omnívoros, con diferentes estilos de vida. Esta omnivoría puede variar desde fitofagia ocasional con artrópodos con un estilo de vida depredador (zoofitófagos) hasta carnivoría ocasional donde predomina un estilo de vida fitófago (fitozoófagos) (Pappas et al., 2015). Una de las características fundamentales que los diferencia del resto de depredadores es que tienen la capacidad de alimentarse tanto de presa como de plantas cuando el nivel de presa es insuficiente para su supervivencia (Castané et al., 2011). Esta capacidad adaptativa les hace ser más persistentes en el tiempo 
cuando la población plaga es escasa, además de anticiparse a una posible infestación por fitófagos. También se ha observado como la presencia regular de estos depredadores sobre los cultivos, favorece el control natural de las plagas disminuyendo los problemas de daños causados por herbivoría si lo comparamos con cultivos donde estos depredadores son escasos (Messelink et al., 2008; Lu et al., 2012). En los últimos años también se ha incrementado su uso para el control biológico de varias plagas en diferentes cultivos (Messelink et al., 2012). Estos depredadores zoofitófagos, como los míridos y antocóridos (Hemiptera: Heteroptera), son excelentes agentes de control biológico para muchas plagas agrícolas (Pérez-Hedo et al., 2015), ya que presentan una doble función sobre el control de los herbívoros. Por una parte, se alimentan directamente de ellos y por otra son capaces de inducir respuestas defensivas en las plantas perjudiciales para los fitófagos. Mientras que es bien conocido el papel que desempeñan los depredadores omnívoros y las interacciones entre plantas y fitófagos, los efectos de la fitofagia de dichos omnívoros sobre las plantas huésped, así como sobre el resto de fauna asociada incluidos los herbívoros y otros enemigos naturales, sólo se empieza a conocer ahora. En la actualidad, todavía se requiere profundizar más en los estudios al respecto, para poder conocer mejor todas estas interacciones y de este modo aprovecharlas para mejorar el control biológico de plagas. En esta tesis, se estudia por primera vez el comportamiento zoofitófago de los ácaros fitoseidos, considerados como otro grupo de omnívoros importante en el control biológico de plagas agrícolas, y sus efectos sobre la planta huésped (los cítricos), el hebívoro (T. urticae) y el resto de componentes del gremio de los depredadores.

\section{Sistema de estudio}

En trabajos previos de nuestro grupo de investigación, Agut et al. $(2014,2015,2016)$ se analizaron los mecanismos de defensa de los cítricos frente al ataque de T. urticae. En dichos estudios se determinaron los mecanismos de defensa directa utilizando dos patrones de cítrico con diferente nivel de susceptibilidad a la araña: el naranjo amargo y el mandarino Cleopatra, ya que estos muestran extrema resistencia y extrema susceptibilidad, respectivamente, dentro del abanico de cítricos estudiado (Bruessow et al., 2010). Los estudios de Agut y colaboradores $(2014,2015,2016)$ demostraron como la ruta del ácido jasmónico (JA) es la efectiva frente a la araña roja. Además gracias a los análisis metabolómicos sabemos que se produce una gran acumulación de diferentes 
flavonoides en el patrón naranjo amargo, posiblemente con función acaricida. Por otra parte, se identificaron y cuantificaron los volátiles liberados por la planta, así como la capacidad de los mismos para inducir resistencia en plantas vecinas. Estos resultados demostraron como el naranjo amargo es capaz de inducir defensa en plantas vecinas de mandarino Cleopatra y que a su vez estos compuestos son repelentes para el herbívoro. Por último, también se llevaron a cabo estudios para averiguar las señales de alerta transmitidas de forma sistémica entre el patrón y la variedad injertada. En este trabajo se pudo ver que el ácido glutámico es la señal que alerta a la planta de forma sistémica sobre los ataques de araña. Puesto que estas respuestas van ligadas a la herbivoría de T. urticae, nos preguntamos si los principales depredadores de este fitófago en los cítricos valencianos podrían también desencadenar respuestas parecidas. Para ello, seleccionamos los 3 fitosidos antes mencionados, que resultaban interesantes por sus distintas especializaciones alimentarias. 



\section{OBJETIVOS}



El principal objetivo de nuestra investigación es determinar si los ácaros fitoseidos son capaces de inducir respuestas defensivas en las plantas que puedan contribuir a mejorar el control biológico de T. urticae. Nuestro sistema de estudio es el formado por cítricoaraña roja-fitoseidos. Este objetivo general, se traduce en los siguientes puntos:

1. Determinar qué rutas metabólicas se activan y qué compuestos volátiles se liberan en cítricos infestados por el depredador zoofitófago E. stipulatus en ensayos de laboratorio, así como el comportamiento de elección de ácaros conespecíficos y del herbívoro T. urticae. Este objetivo se ha desarrollado en el capítulo 1.

2. Estudiar el comportamiento de $N$. californicus y P. persimilis a infestaciones por ácaros conespecíficos, así como el comportamiento de su presa T. urticae en ensayos de elección, determinando a su vez si estos fitoseidos especialistas de tetraníquidos, inducen alguna respuesta defensiva en las plantas. Este objetivo se ha desarrollado en el capítulo 2 .

3. Caracterizar los principales compuestos volátiles liberados por cada uno de los fitoseidos estudiados en el presente trabajo, analizando cuál es el comportamiento de cada uno de ellos frente a su propio olor y al de las otras dos especies de forma aislada, con o sin planta.

4. Analizar el aprovechamiento de T. urticae procedente de naranjo amargo y mandarino Cleopatra por parte de cada uno de los tres fitoseidos. Estos dos últimos objetivos se han desarrollado en el capítulo 3. 



\section{CAPÍTULO 1}

\section{Zoophytophagous mites can trigger plant-genotype specific defensive responses}

affecting potential prey beyond predation: the case of Euseius stipulatus and Tetranychus urticae in citrus

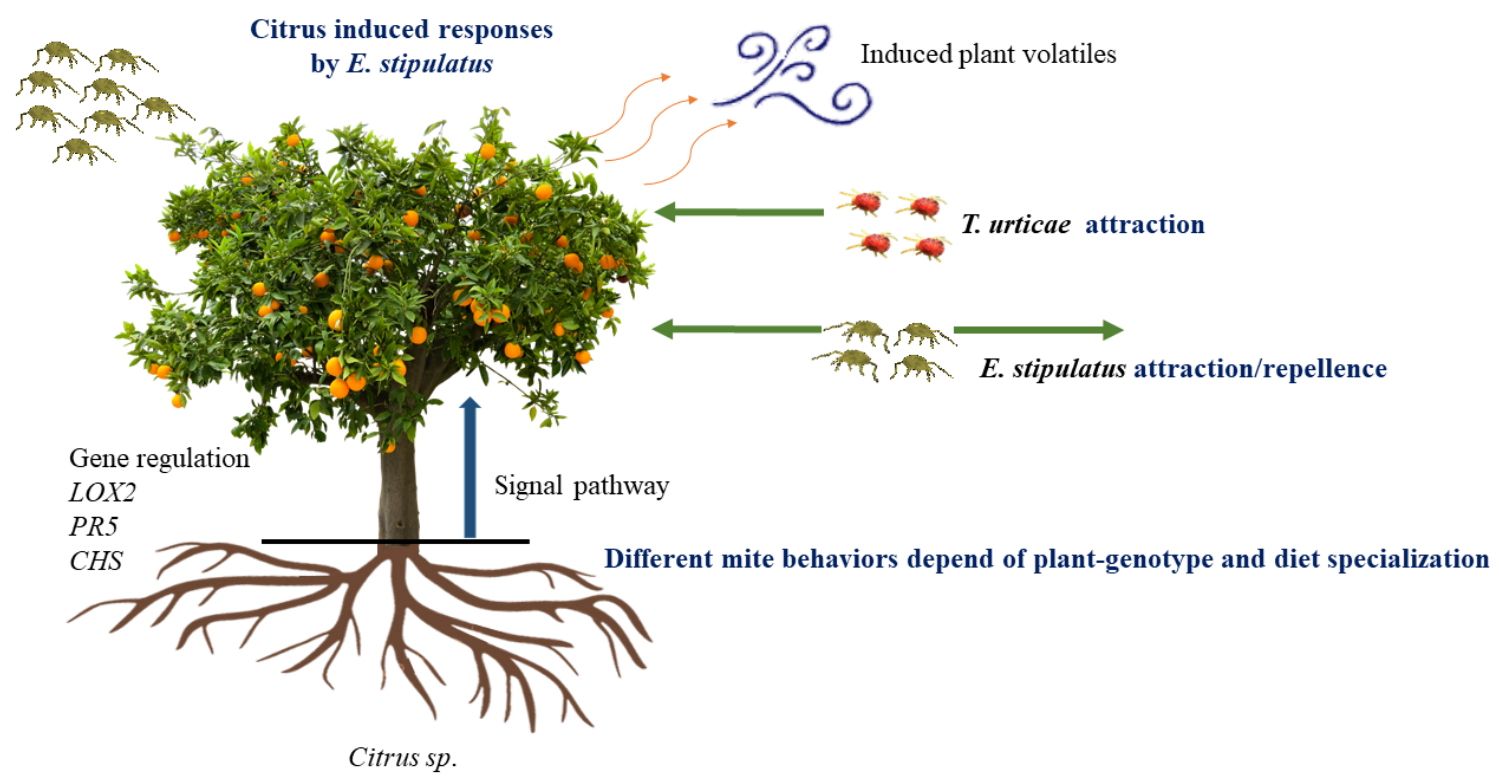

Adapted from:

Joaquín Cruz-Miralles, Marc Cabedo-López, Meritxell Pérez-Hedo, Víctor Flors and Josep A Jaques. 2019. Zoophytophagous mites can trigger plant-genotype specific defensive responses affecting potential prey beyond predation: the case of Euseius stipulatus and Tetranychus urticae in citrus DOI: 



\begin{abstract}
Zoophytophagous predators can trigger plant defense affecting prey populations beyond predation. Euseius stipulatus is a presumed zoophytophagous phytoseiid common in citrus. The response of citrus to one of its potential prey, T. urticae, is genotype dependent, with Citrus reshni and C. aurantium exhibiting extreme susceptibility and resistance, respectively. Volatile blends produced upon occupation by E. stipulatus affected the behavior of these two mites. We wondered whether E. stipulatus could trigger similar responses.

E. stipulatus triggered genotype-dependent defense responses in citrus. While $C$. aurantium upregulated the JA, SA and flavonoids defensive pathways, C. reshni upregulated JA only. Likewise, different volatile blends were induced. These blends were exploited by E. stipulatus to select less defended plants (i.e., those where higher pest densities are expected) and, interestingly, did not prevent $T$. urticae from choosing $E$. stipulatus-occupied plants. To the best of our knowledge this is the first time that this type of responses is described for a zoophytophagous phytoseiid.

The observed responses could affect herbivore populations through plant-mediated effects. Although further research is needed to fully characterize them and include other arthropods in the system, these results open opportunities for more sustainable and effective pest control methods (i.e., combining semiochemicals and biological control).
\end{abstract}





\subsection{Introduction}

Omnivores are consumers that feed on resources at more than one trophic level (Pimm and Lawton, 1978). In the case of arthropods, Coll and Guershon, (2002) called true omnivores those species that feed on both plants and prey in nature. This category contains many terrestrial arthropods including plant feeding predators, which are also known as zoophytophagous predators (Lalonde et al., 1999). Among these species, predatory bugs (Hemiptera: Heteroptera), especially Miridae, have recently received attention because of their increasing interest as biological control agents in augmentative releases against important agricultural pests (Arnó et al., 2009; De Puysseleyr et al., 2011; Perdikis et al., 2011; Messelink et al., 2015; Pappas et al., 2015; Pérez-Hedo et al., 2015; Naselli et al., 2016; Bouagga et al., 2018; Zhang et al., 2018). These omnivores affect the performance of herbivores not only directly by predation but also through induced plant defense (see references above). Zoophytophagy, though, is not restricted to Heteroptera. Phytoseiidae mites (Acari: Mesostigmata) constitute another important group of omnivorous biological control agents (Van Lenteren, 2012; Van Lenteren et al., 2018). Several studies have shown that some phytoseiid species can feed directly on the plant (Magalhães and Bakker, 2002; Nomikou et al., 2003; Adar et al., 2012). Cheliceral traits typical of phytoseiid plant feeders have been observed in five genera including the genus Euseius De Leon (Adar et al., 2012; McMurtry et al., 2013). Leaf-feeding in this genus, though, may be plant specific. In a study where leaf feeding on plants labeled with radioactive phosphoric acid by the omnivorous predators Euseius hibisci (Chant), E. fructicolus (Gonzales and Schuster), and E. stipulatus (Athias-Henriot) was evaluated, only E. hibisci proved to feed from avocado leaves, its natural host, whereas none of them showed evidence of feeding from lemon foliage (Porres et al., 1975). The genus Euseius is one of the most common genera in citrus worldwide (Grout, 1994; McMurtry et al., 1985). Indeed, E. stipulatus is the most abundant phytoseiid species in citrus orchards in the Mediterranean basin (McMurtry, 1977). In Spain, this prevalence occurs both in the canopy and in the cover crops associated with citrus, irrespective of the species/cultivar and management practices used in the orchard (Abad-Moyano et al., 2009b; AguilarFenollosa et al; 2011a; Jaques et al., 2015). This mite species is considered key for the natural population control of two important tetranychid herbivorous pest species in citrus, the two-spotted spider mite Tetranychus urticae Koch and the citrus red mite Panonychus citri McGregor (Ferragut et al., 1988; Pérez-Sayas et al., 2015). According to Adar et al. 
(2012) phytoseiid direct leaf feeding could be cultivar specific, and this could explain the results of Porres et al. (1975) with E. stipulatus on lemon leaves. The occurrence of such a behavior in this species would most probably imply induce defense mechanisms in plants, which could trigger further effects on conspecifics and other co-occurring species, including potential prey. Therefore, we decided to focus our attention on the system constituted by citrus, T. urticae and E. stipulatus.

In previous studies, our group demonstrated that the responses of citrus to damage from T. urticae was genotype dependent (Agut et al., 2015; Bruessow et al., 2010; Agut et al., 2016). Sour orange, Citrus aurantium L. (Sapindales: Rutaceae), showed reduced leaf damage symptoms, supported lower mite populations and reduced oviposition rates compared with Cleopatra mandarin, Citrus reshni Hort. ex Tan. These effects were transmitted from the roots to the grafted cultivar. Hormonal, metabolomic and gene expression analyses of the main defense pathways indicated a relevant role of the oxylipin and the flavonoid pathways. Furthermore, when T. urticae and E. stipulatus had to choose between occupied sour orange and Cleopatra mandarin, they preferred poorly defended Cleopatra mandarin plants (Bruessow et al., 2010; Agut et al., 2016). This result was observed irrespective of the occupation status of the plant (i.e., occupied and unoccupied plants) for T. urticae, whereas E. stipulatus preferred sour orange when both genotypes were unoccupied (same authors, unpublished). These results were attributed to the different volatile blends (including Herbivore Induced Plant Volatiles, HIPVs, for occupied plants) produced. Because the HIPVs produced by sour orange can induce resistance in Cleopatra mandarin, (Agut et al., 2015) the effect of induction on mite choice was further studied. Tetranychus urticae still preferred less defended unoccupied Cleopatra plants, whereas E. stipulatus chose better protected but prey-free induced mandarin plants (same authors, unpublished). As the blends produced by occupied sour orange, and induced Cleopatra mandarin proved attractive to phytoseiids but not to the herbivore, (Agut et al., 2016) they may pave the way for developing new sustainable tools to manage these species. Should E. stipulatus feed on the plant, similar responses are expected. In this study, we have characterized the response of the two citrus genotypes mentioned earlier to E. stipulatus occupation, as well as the behavior of T. urticae and E. stipulatus, when offered unoccupied and E. stipulatus-occupied plants. Our initial hypothesis is that because of the presumed feeding of E. stipulatus in citrus, the observed responses will be genotype dependent and similar to those already observed upon $T$. 
urticae infestation. In short, plants with relatively stronger activation of direct defense pathways against $T$. urticae (i.e., oxylipins, flavonoids) upon E. stipulatus feeding should be avoided by the zoophytophagous predator. Keep in mind that these plants would offer higher levels of potentially toxic secondary metabolites relative to less defended hosts and, therefore, would sustain lower prey densities (Agut et al., 2014). The same rationale would apply to the herbivore. However, in both cases, to decrease predation/cannibalism risk, an over-ruling of predator odors over HIPVs could result in a preference for unoccupied versus E. stipulatus-occupied plants.

\subsection{Materials and methods}

\subsubsection{Plant material}

Sour orange (C. aurantii) and Cleopatra mandarin (C. reshni), the two citrus rootstocks exhibiting extreme responses to T. urticae (Bruessow et al., 2010; Agut et al., 2014; Agut et al., 2016) were used. Three-month-old plants of both species (with about 10 fully developed leaves) were maintained in a climatic chamber at $60 \pm 10 \%$ relative humidity (RH) and under a 16:8 h L:D (light:dark) photoperiod combined with a day/night thermal regime of $25 \pm 2^{\circ}$ and $20 \pm 2^{\circ} \mathrm{C}$, respectively. These plants were grown on vermiculite and peat (1:3; v:v) in 320-ml pots. No insecticides or acaricides were used and fertilization consisted of a modified Hoagland's solution applied every 3 days (Bañuls et al., 1997). Lemon fruits obtained from a pesticide-free experimental orchard at UJI Campus were used to maintain T. urticae stock colonies. Finally, bean plants (Phaseolus vulgaris L. cv. Buenos Aires roja) grown at UJI greenhouse in pesticide-free conditions were used to maintain E. stipulatus colonies.

\subsubsection{Spider mite stock colony}

The colony of T. urticae used in the assays was initiated with specimens collected in clementine orchards in the region of La Plana (Castelló, Spain) in 2001. To avoid maternal effects that could affect offspring fitness by rendering the offspring phenotype better suited to its future host (Freinschlag and Schausberger, 2016), spider mites were maintained on lemons which were kept in a climatic chamber $\left(22 \pm 2.5^{\circ} \mathrm{C}\right.$ and $75 \pm 5 \%$ RH and 16:8 h L:D photoperiod). Colonies consisted of 8-10 lemons, which were replaced weekly in groups of four. Adult females obtained from these stock colonies were 
directly used in Y-tube olfactory choice assays (see below). In this case, females were subjected to a 24-h starvation period before the assay. Starvation took place in $50 \mathrm{ml}$ plastic vials where mites in groups of 15 could drink on a $2 \mathrm{~cm}$ in diameter water-soaked cotton ball.

\subsubsection{Euseius stipulatus stock colony}

This colony was initiated with specimens collected in clementine orchards in Montcada, not far from UJI Campus, in 2012. These phytoseiids were maintained in a climatic chamber at the same environmental conditions as above. The rearing took place on detached leaf units consisting of a single bean leaflet placed upside down on moistened cotton, placed on top of a water-saturated foam cube (3-4 cm thick) in an open plastic box $\left(35 \times 20 \times 7 \mathrm{~cm}^{3}\right)$ half-filled with water. Moist cotton was folded over the edges of the leaves to prevent mites from escaping. Typha L. spp. (Typhaceae) pollen, was added every 3 days to feed this phytoseiid mite. Same as before, adult females of this predatory mite were directly removed from the colony and subjected to a 24-h starvation period in vials in groups of seven before use in the Y-tube olfactory choice assays. Furthermore, specimens from this colony were also used to populate citrus plants for the same assays and for those where plant volatiles were extracted. When used as an odor source, 25 adult females were either deposited on different leaves of the same plant using a soft-bristle paintbrush, or moved to a meshed bag $(10 \times 5 \mathrm{~cm})$ closed with a magnet. Occupied plants remained in a climatic chamber for up to 48 hours at the same environmental conditions as those explained in 'Plant Material'. Plants were grouped by both genotype and occupation status to avoid any exposure to plant volatiles from the other treatments, which could induce undesired defensive responses (Agut et al., 2015).

\subsubsection{Y-tube olfactory choice assays}

Olfactory choice assays were conducted using a Y-tube olfactometer according to Bruin et al. (1992). This assay involves the use of a 4-cm-diameter, Y-shaped glass tube with a 13-cm base and two 13-cm arms containing a Y-shaped 1-mm diameter metal wire of the same dimensions, which occupies the core of the olfactometer. The two arms were directly connected via a plastic pipeline to the outlets of two identical 5-1 glass vessels containing different odor sources. Each vessel was connected to an air pump that 
produced a unidirectional airflow of $1.5 \mathrm{l} / \mathrm{h}$ from the arms to the base of the tube. The air was purified with a granular activated charcoal filter (Sigma-Aldrich). The environmental conditions inside the Y-tube were $23 \pm 2{ }^{\circ} \mathrm{C}$ and $60 \pm 10 \% \mathrm{RH}$. Tested females were starved with access to water during the $24 \mathrm{~h}$ prior the assay. Females were individually deposited at the beginning of the long arm of the wire using a soft-bristle paintbrush. Females were allowed to make a choice within $10 \mathrm{~min}$. As soon as a mite reached the end of one of the two arms of the tube, the mite was removed from the set-up and discarded. Mites failing to reach either end of the arms within the allocated time were scored as 'no choice'. Different 2-choice experiments involving occupied and unoccupied plants of both genotypes, as well as E. stipulatus alone were performed. Each combination was evaluated four times at different dates (i.e., four replicates). Each replicate included 10 responding mites, which meant that up to 13 mites per combination per date were tested as non choosing individuals ranged from 0 to 3 . The glass vessels were switched after five females had been tested to account for potential effects of space on mite choice. In the case of assays with plants, the plants were replaced after every 10 females had been tested, and the whole system was rinsed with ethanol (70\%), followed by drying air. To exclude any bias from the set-up, before the beginning of the assays, 10 mites were exposed to clean air in both arms. A random choice was expected.

\subsubsection{Quantitative real-time reverse transcription-polymerase chain reaction (qRT- PCR) analysis}

Three assays including 3 plants per treatment each were carried out. For each assay, six sour orange and six Cleopatra mandarin plants were used. For each genotype three plants were occupied with E. stipulatus as previously explained, whereas the other three remained unoccupied and were used as controls. 48 hours after occupation at the same temperature and RH conditions as before, leaves were cut and immediately introduced into $50 \mathrm{ml}$ Falcon vials, which were immersed in liquid nitrogen and stored at $-80^{\circ} \mathrm{C}$ until extraction. Leaves from the same treatment were pulled together in the same vial. RNA was extracted using a Plant RNA protocol with trizol. For qRT-PCR experiments, $1 \mu \mathrm{g}$ of total RNA was digested with $0.7 \mu \mathrm{g}$ of DNase (RNase-free DNase I) in $0.7 \mu$ l of DNase buffer and Milli-Q water up to $4.9 \mu 1$ and incubated for $30 \mathrm{~min}$ at $37^{\circ} \mathrm{C}$. After incubation, $0.7 \mu 1$ of EDTA was added and incubated again at $65^{\circ} \mathrm{C}$ for 10 min to inactivate DNase (Thermofisher Scientific Inc.). The RT reaction was performed by adding $7 \mu$ l of DNase 
reaction, $2 \mu 1$ of PrimeScript buffer and $0.5 \mu 1$ of PrimeScript RT and Oligo-dT respectively (PrimeScript RT Reagent Kit, Takara Bio Inc.). The reaction mixture was incubated at $37^{\circ} \mathrm{C}$ for $15 \mathrm{~min}$. Complementary DNA from the RT reaction, 10X diluted, was used for qPCR. Forward and reverse primers $(0.3 \mu \mathrm{M})$ were added to $5 \mu 1$ of Maxima SYBR Green qPCR Master Mix, $1 \mu 1$ of cDNA and $3 \mu 1$ Milli-Q sterile water (Maxima SYBR Green/ROX qPCR, Thermofisher Scientific Inc.). qPCR was carried out using the Smart Cycler II (Cepheid, Sunnyvale, CA, USA) sequence detector with standard PCR conditions. qRT-PCR analysis was replicated three times. The expression of lipoxygenase $2 \quad\left(L O X 2 ; \quad\right.$ accession Cit.16756.1.S1_ s_at; forward primer: $5^{\prime} \rightarrow 3^{\prime}$ GAACCATATTGCCACTTTCG; CGTCATCAATGACTTGACCA) pathogenesis-related protein 5 (PR5; accession BAI63297.1; forward primer: 5' $\rightarrow$ 3' CATCAAGCTTCACAGTGCTTAG; reverse primer 5' $\rightarrow$ 3': CCACAACGTACAGACTGATGAC) and Chalcone synthase ( $C H S$; accession CF417078; forward primer: 5' $\rightarrow$ 3': AGACGATCCTCCCTGACTCT; reverse primer 5' $\rightarrow$ 3': CTCCACTTGGTCCAGAATTG) genes was determined (Agut et al., 2014). Relative expression was compared with the housekeeping gene glyceraldehyde 3 phosphate dehydrogenase $(G A P D H$; accession Cit.122.1; forward primer: 5' $\rightarrow$ ': GGAAGGTCAAGATCGGAATCAA; reverse primer $\quad 5^{\prime} \rightarrow 3^{\prime}$ : CGTCCCTCTGCAAGATGACTCT).

\subsubsection{Collection of headspace volatiles in plants occupied by $E$. stipulatus}

Volatiles from the two citrus genotypes, including unoccupied and E. stipulatus-occupied plants, were collected using a headspace collection system similar to that described by Bruinsma et al. (2010). 5-1 glass vessels (Duran, Mainz, Germany) ventilated with carbonfiltered pressure-air at $1.51 \mathrm{~h}^{-1}$ were used. Pasteur pipettes with $300 \mathrm{mg}$ of Porapak (Sigma-Aldrich, Barcelona, Spain) were used as a volatile retention filter. These filters were in the air outlet hole at the top of the glass vessel. Plants were individually introduced into these glass vessels. The system (glass vessels and Porapak filters) was cleaned with acetone and dried in an oven 1 hour prior to the assay. Volatiles collection took place in a climatic chamber at $60 \pm 10 \% \mathrm{RH}$ and under a 16:8 h L:D photoperiod combined with a day/night thermal regime of $25 \pm 2^{\circ}$ and $20 \pm 2^{\circ} \mathrm{C}$, respectively. When necessary, plants were occupied with 25 E. stipulatus adult females, (as explained above) which could feed directly on the plant, cannibalize conspecifics, or try to escape. In this 
case, the volatiles were collected during the first 24 hours of occupation as maintaining the plants under these conditions for longer (i.e., 48 hours as in the previous assays) resulted in deposition of water droplets in the interior of the vessel. These droplets may affect the efficiency of the collection. Furthermore, previous studies showed that gene expression and hormone concentration in occupied citrus plants did not significantly change between 24 and 48 hours post occupation (Agut et al., 2014). Three plants per genotype and occupation status were considered in each of the three replicates of this assay.

\subsubsection{Gas chromatography (GC) instrumentation}

An Agilent 6890N GC system (Palo-Alto, CA, USA), equipped with an Agilent 7683 autosampler, coupled to a time-of-flight mass spectrometer (TOF-MS), GCT (Waters Corp., Manchester, UK), operating in electron ionization (EI) mode were used in our assays. A fused silica DB-5MS capillary column of $30 \mathrm{~m}$ length, $0.25 \mathrm{~mm}$ internal diameter and a film thickness of $0.25 \mu \mathrm{m}$ (J\&W Scientific, Folson, CA, USA) were used for $\mathrm{GC}$ separation. The temperature program for this process was the following; $50^{\circ} \mathrm{C}$ (1min); $5^{\circ} \mathrm{C} \mathrm{min}^{-1}$ to $210^{\circ} \mathrm{C}(1 \mathrm{~min}) ; 20^{\circ} \mathrm{C} \mathrm{min}^{-1}$ to $300^{\circ} \mathrm{C}(2 \mathrm{~min})$; this resulted in a total analysis run of $40.50 \mathrm{~min}$. Splitless injections were carried out. Helium was used as carrier gas at $1 \mathrm{ml} \mathrm{min}{ }^{-1}$. The interface and source temperatures were both set to $250^{\circ} \mathrm{C}$ and a solvent delay of $3 \mathrm{~min}$ was selected. The TOF-MS was operated at 1 spectrum $\mathrm{s}^{-1}$ acquiring the mass range $\mathrm{m} / \mathrm{z} 50-650$ and using a multi-channel plate voltage of $2800 \mathrm{~V}$. The TOF-MS resolution was c. 8500 (full width at half-maximum, FWHM) at m/z 614. Heptacose, used for the daily mass calibration as well as lock mass, was injected via syringe into the reference reservoir at $30^{\circ} \mathrm{C}$. The $\mathrm{m} / \mathrm{z}$ ion monitored was 218.9856 . The application manager ChromaLynx, a module of MassLynx software, was used to investigate the presence of non-target compounds in the samples.

The retention time and fragmentation spectrum of the following commercial standards were used to identify volatile compounds: methyl salicylate (MeSA) and methyl jasmonate (MeJA) (Sigma-Aldrich). Other volatile compounds were tentatively identified using GC-MS and matching to the National Institute of Standards and Technology (NIST) Library, using Match values of at least 850 as a threshold for identification, as 
described by Wallis et al. (2008). Furthermore, for each HIPV identified the TOF-MSderived peak areas were calculated and used to estimate their relative concentration.

\subsubsection{Statistical analyses}

Statistical analyses were conducted using IBM SPSS Statistics 23. The results of the twochoice assays were initially subjected to logistic regression to check for the effect of replicate $(n=4)$ on mite preference. Depending on whether this effect was significant or not $(P>0.05)$, either each single replicate or the combination of the four, respectively, were subjected to chi-square analysis to test whether they departed from a 1:1 distribution. Student $t$-test was used to compare the results of the genetic expression results. For each volatile identified in the blends produced by plants, TOF-MS-derived peak areas were compared using a Generalized Linear Model (GLM) with a normal distribution of the error and identity link function (i.e, linear regression). Plant genotype, occupation status, and replicate were used as fixed effects. When necessary, we used Bonferroni post-hoc test $(P<0.05)$ for mean separation.

\subsection{Results}

\subsubsection{E. stipulatus-occupied citrus plants modify the behavior of conspecifics and also of the potential prey $T$. urticae}

As the effect of the factor 'replicate' was not significant in any case, for each 2-choice experiment, the results were pooled and subjected to chi-square test. In agreement with our initial hypothesis that E. stipulatus odors would result repellent for T. urticae, twospotted spider mite adult females avoided E. stipulatus when exposed to the predator odors alone (Figure 1.1). However, contrary to our expectations, when E. stipulatus was occupying the plants, these resulted attractive for T. urticae irrespective of the genotype. Indeed, when T. urticae was simultaneously exposed to the two infested citrus genotypes, no preference for any of them was observed whereas a preference for Clementine mandarin was observed when the same genotypes were unoccupied. Likewise, contrary to our expectations, E. stipulatus females did not avoid conspecifics when exposed to their own odors alone (Figure 1.2). However, when HIPVs were at play, their response was genotype dependent. As expected, E. stipulatus-occupied Cleopatra mandarin plants resulted attractive, whereas occupied sour orange became repellent. Moreover, when the 
two genotypes were simultaneously offered, a preference for Cleopatra mandarin was observed when plants were occupied, whereas sour orange was preferred when plants were unoccupied.

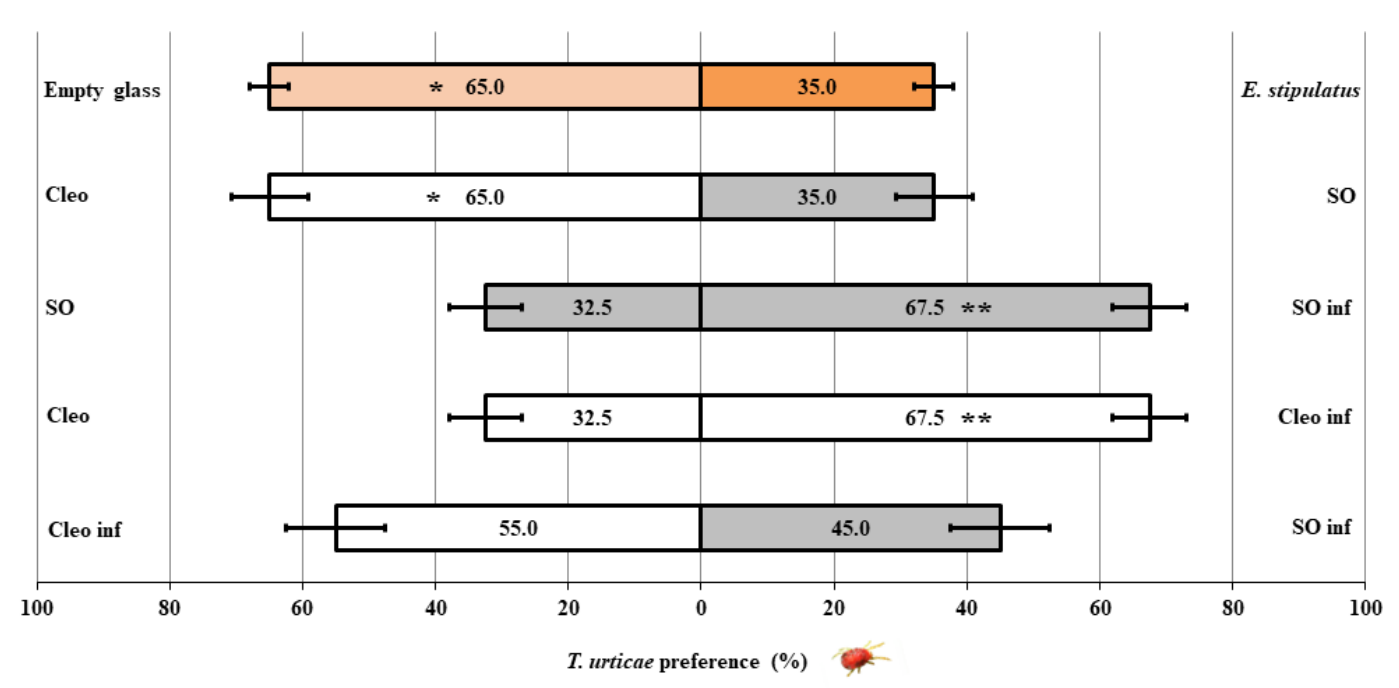

Figure 1.1 Olfactory responses of $T$. urticae adult females to E. stipulatus. Five different combinations, in which $T$. urticae had to choose between two odor sources, were tested. A minimum of 40 adult females per choice combination was tested. From top to bottom these combinations were: empty glass versus E. stipulatus, Cleopatra mandarin unoccupied plants (Cleo) vs sour orange unoccupied plants (SO), SO vs SO-occupied plants (SO inf), Cleo vs Cleooccupied plants (Cleo inf), and Cleo inf vs SO inf. Infested plants had been exposed to $25 \mathrm{E}$. stipulatus adult females for $48 \mathrm{~h}$ before the onset of the assay. Asterisks indicate significant differences from a 1:1 distribution (one asterisk: chi-square test $P<0.10$, two asterisks: chi-square test $P<0.05$ ). 


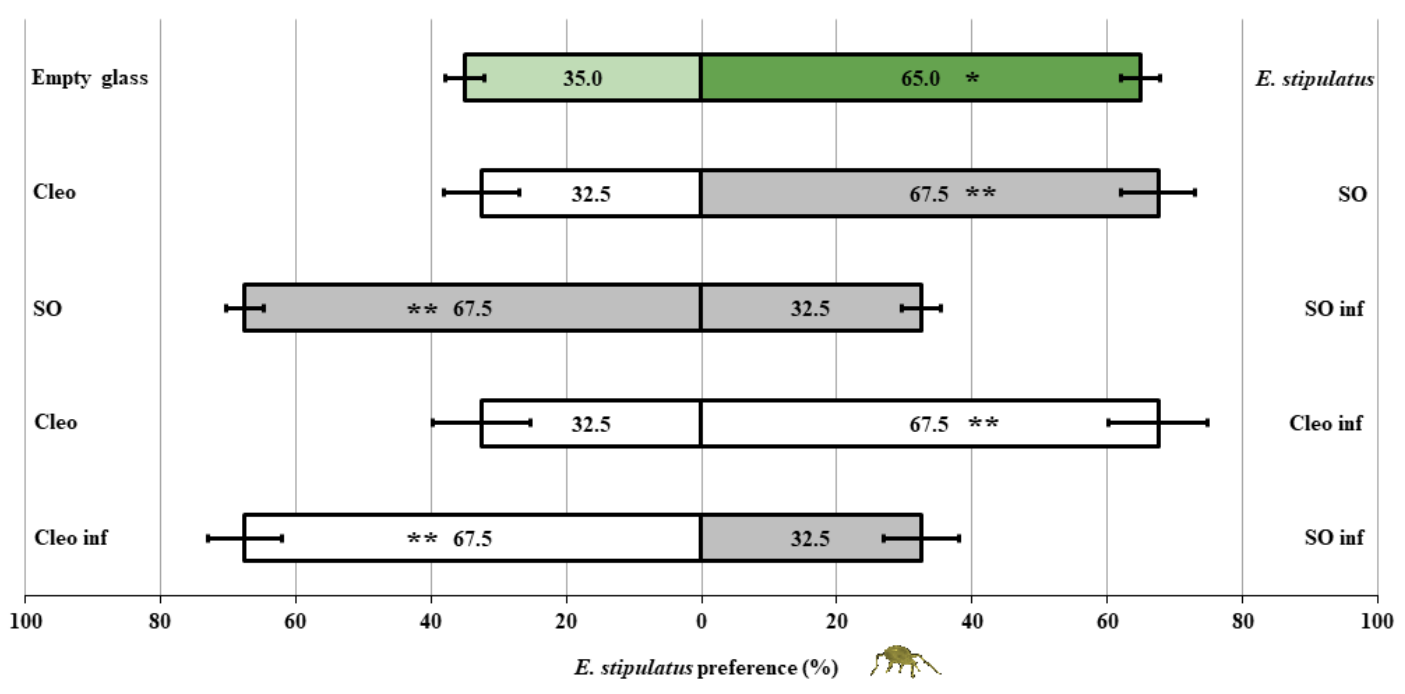

Figure 1.2 Olfactory responses of E. stipulatus adult females to conspecific mites. Five different combinations, in which E. stipulatus had to choose between two odor sources were tested. A minimum of 40 adult females per choice combination was tested. From top to bottom these combinations were: empty glass versus E. stipulatus, Cleopatra mandarin unoccupied plants (Cleo) vs sour orange unoccupied plants (SO), SO vs SO-occupied plants (SO inf), Cleo vs Cleooccupied plants (Cleo inf), and Cleo inf vs SO inf. Occupied plants had been exposed to $25 \mathrm{E}$. stipulatus adult females for $48 \mathrm{~h}$ before the onset of the assay. Asterisks indicate significant differences from a 1:1 distribution (one asterisk: chi-square test $P<0.10$, two asterisks: chi-square test $P<0.05$ ).

\subsubsection{The generalist predator $E$. stipulatus triggers defensive responses in sour orange and Cleopatra mandarin plants}

The JA, SA, and flavonoid signaling pathways homologous marker genes $L O X 2, P R 5$, and $C H S$, respectively, were analyzed in unoccupied and E. stipulatus-occupied plants. $L O X 2$ relative expression was 2.5 times higher in occupied than in unoccupied plants irrespective of the plant genotype (Figure 1.3A). However, for the other two marker genes, plant-genotype differences were observed. PR5 and CHS expressions were enhanced in sour orange $(\times 2.2$ and $\times 1.2$, respectively), whereas PR5 did not change and CHS was downregulated $(\times 0.7)$ in Cleopatra mandarin (Figures $1.3 \mathrm{~B}$ and $1.3 \mathrm{C}$ ). 

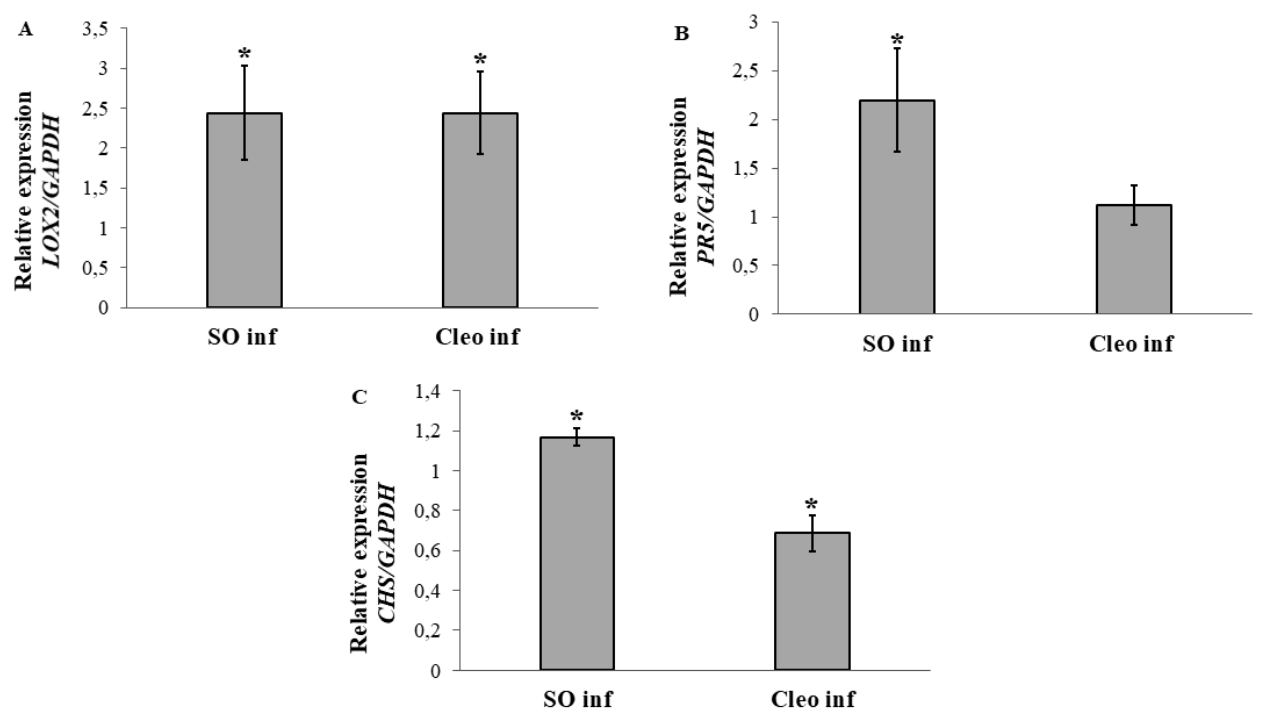

Figure 1.3 Relevance of: A. Lypoxigenase 2, LOX2 (cit16759.1S1), B. Pathogenesis-related protein 5, PR5 (BAI63287.1), and C. Chalcone synthase, CHS (CF417078), in citrus defense triggered by E. stipulatus. Total RNA was extracted from the leaves of three plants per genotype (sour orange, SO, and Cleopatra mandarin, Cleo) and occupiation status (unoccupied and occupied with 25 mites, inf) 48 hours after occupiation, converted to cDNA and subjected to quantitative RT-PCR analysis. Transcript levels were normalized to the expression of the housekeeping gene glyceraldehyde 3-phosphate dehydrogenase (GAPDH) measured in the same sample. For each genotype, data are presented as a mean of transcript expression relative to unoccupied plants $\pm \mathrm{SE}(\mathrm{n}=3)$. Significant differences between unoccupied and occupied plants were estimated performing a t-test for each genotype. Asterisks indicate statistically significant differences $(P<0.05)$.

\subsubsection{The generalist predator $E$. stipulatus triggers the production of volatiles (HIPVs) in sour orange and Cleopatra mandarin plants}

GLM results showed differences in the volatile metabolome of occupied relative to unoccupied plants, which also suggest that E. stipulatus can feed directly on citrus plants. The factor 'replicate' and all the 2- and 3-factor interactions where it was included in the GLM used were significant. The reason is that for each HIPV identified, the TOF-MSderived peak areas obtained for each replicate could be up to two orders of magnitude apart. However, as the relative differences observed for the other two factors considered (plant genotype and occupation) for each volatile were consistent (Figure 1.4), results were interpreted in a qualitative manner and according to these two factors only. From the 11 compounds identified in these blends, four of them did not change with occupation and plant genotype. These were 1,4-diethyl-Benzene, 1-(4-ethylphenyl)-Ethanone, 4Butoxybutanoic acid, and 3,5-di-tert-Butyl-4-hydroxybenzaldehyde. The remaining 7 compounds showed different trends (Table 1.1, Figure 1.4). The terpenoid Pinene 
decreased with occupation irrespective of the genotype (Figure 1.4A). The production of another terpenoid, Cineole (Figure 1.4B), and that of the aromatic compound 1-(2,5dimethylphenyl)-Ethanone (Figure 1.4C) showed a common trend: they were higher in sour orange than in Cleopatra mandarin and decreased with occupation. The other 4 HIPVs, the Green Leaf Volatile 2,6,10-Dodecatrienoic acid, and the aromatic compounds 1-methyl-4-(2-propenyl)-Benzene, 1-ethyl-4-(1-methylethyl)-Benzene, and 4-(1methylethyl)-Benzaldehyde (Figures 1.4D, 1.4E, 1.4F and 1.4G, respectively), also showed another common trend. In this case, they increased with occupation and were higher in Cleopatra mandarin.

Table 1.1 Volatile profiling in the headspace of sour orange (SO) and Cleopatra mandarin (Cleo) plants either clean or occupied (inf). For each volatile, TOF-MS-derived peak areas were compared using a Generalized Linear Model. Plant genotype, occupation status, and replicate were used as fixed effects. As replicate and all the interactions including this factor were significant $(P<0.05)$, these results are not presented in the table. As the relative differences observed for the other two factors considered were consistent for each volatile, results were interpreted in a qualitative manner and according to these two factors only. Volatiles were tentatively identified by comparing to the National Institute of Standards and Technology (NIST) Library as described by Wallis et al. (2008).

\begin{tabular}{|c|c|c|c|}
\hline \multirow[b]{2}{*}{ Volatile compounds } & \multicolumn{3}{|c|}{ GLM results $^{1}\left(\right.$ Wald $\left.-\chi^{2} ; P\right)$} \\
\hline & $\begin{array}{l}\text { Plant genotype } \\
\text { (A) }\end{array}$ & $\begin{array}{l}\text { Occupation status } \\
\text { (B) }\end{array}$ & $A * B$ \\
\hline Pinene & $\begin{array}{l}0.04 ; 0.951 \\
\mathrm{SO}=\text { Cleo }\end{array}$ & $\begin{array}{c}153.60 ;<0.001 \\
\text { clean }<\text { inf }\end{array}$ & $0.174 ; 0.677$ \\
\hline Cineole & $\begin{array}{l}3.82 ; 0.051 \\
\mathrm{SO}>\text { Cleo }\end{array}$ & $\begin{array}{c}19.17 ;<0.001 \\
\text { clean }>\text { inf }\end{array}$ & $\begin{array}{c}5.29 ; 0.021 \\
\text { SO clean }>\text { SO inf }=\text { Cleo clean }=\text { Cleo } \\
\inf \end{array}$ \\
\hline $\begin{array}{l}\text { Ethanone, 1-(2,5- } \\
\text { dimethylphenyl) }\end{array}$ & $\begin{array}{c}52.92 ;<0.001 \\
\mathrm{SO}>\text { Cleo }\end{array}$ & $\begin{array}{c}12.00 ; 0.001 \\
\text { clean }>\text { inf }\end{array}$ & $\begin{array}{c}12.00 ; 0.001 \\
\text { SO clean }>\text { SO inf }>\text { Cleo clean }=\text { Cleo } \\
\inf \end{array}$ \\
\hline 2,6,10-Dodecatrienoic acid & $\begin{array}{c}35.28 ;<0.001 \\
\mathrm{SO}<\text { Cleo }\end{array}$ & $\begin{array}{l}6.92 ; 0.009 \\
\text { clean }<\text { inf }\end{array}$ & $\begin{array}{c}26.91 ;<0.001 \\
\text { SO clean }=\text { SO inf }=\text { Cleo clean }<\text { Cleo } \\
\text { inf }\end{array}$ \\
\hline $\begin{array}{l}\text { Benzene, 1-methyl-4-(2- } \\
\text { propenyl)- }\end{array}$ & $\begin{array}{c}37.94 ;<0.001 \\
\mathrm{SO}<\text { Cleo }\end{array}$ & $\begin{array}{c}61.04 ;<0.001 \\
\text { clean }<\text { inf }\end{array}$ & $\begin{array}{c}27.30 ;<0.001 \\
\text { SO clean }<\text { SO inf }=\text { Cleo clean }<\text { Cleo } \\
\inf \end{array}$ \\
\hline $\begin{array}{l}\text { Benzene, 1-ethyl-4-(1- } \\
\text { methylethyl)- }\end{array}$ & $\begin{array}{c}65.34 ;<0.001 \\
\mathrm{SO}<\text { Cleo }\end{array}$ & $\begin{array}{c}57.82 ;<0.001 \\
\text { clean }<\inf \end{array}$ & $\begin{array}{c}49.11 ;<0.001 \\
\text { SO clean }=\text { SO inf }=\text { Cleo clean }<\text { Cleo } \\
\inf \end{array}$ \\
\hline $\begin{array}{l}\text { Benzaldehyde, 4-(1- } \\
\text { methylethyl)- }\end{array}$ & $\begin{array}{c}131.05 ;<0.001 \\
\mathrm{SO}<\text { Cleo }\end{array}$ & $\begin{array}{c}123.62 ;<0.001 \\
\text { clean }<\text { inf }\end{array}$ & $\begin{array}{c}124.51 ;<0.001 \\
\text { SO clean }=\text { SO inf }=\text { Cleo clean }<\text { Cleo } \\
\inf \end{array}$ \\
\hline
\end{tabular}

$\mathbf{1}$ df were always 1. For volatiles for which the Plant*Occupation interaction is significant, means were separated according to Bonferroni $(P<0.05)$. 
A

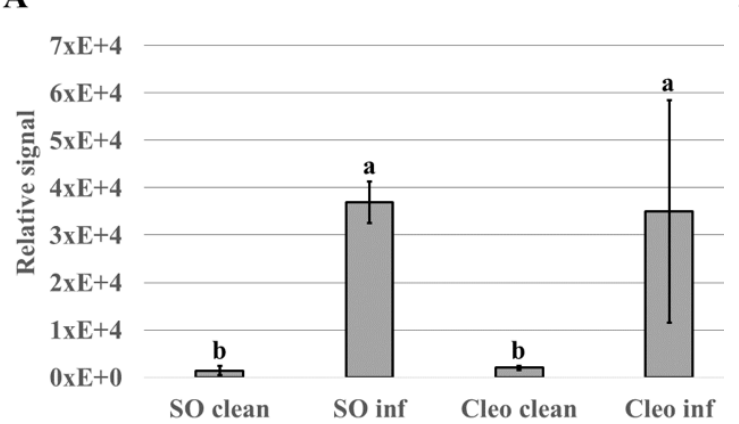

C

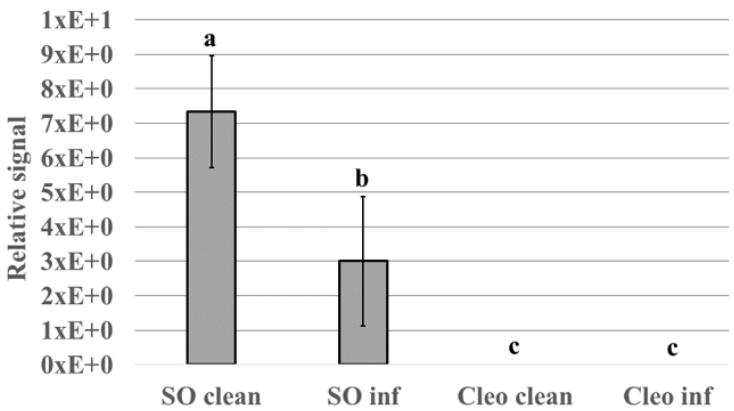

$\mathbf{E}$

E $5 \mathrm{xE}+3$

$4 \mathrm{xE}+3$

$4 \mathrm{xE}+3$

$\overline{\mathrm{IJ}} 3 \mathrm{xE}+3$

$3 \times \mathrm{xE}+3$

$2 \mathrm{xE}+3$

要 $2 \mathrm{xE}+3$

$1 \mathrm{xE}+3$

$5 \mathrm{xE}+2$

$0 \times \mathrm{E}+0$

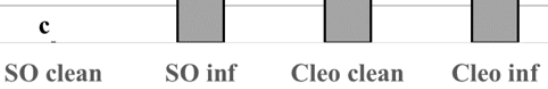

B

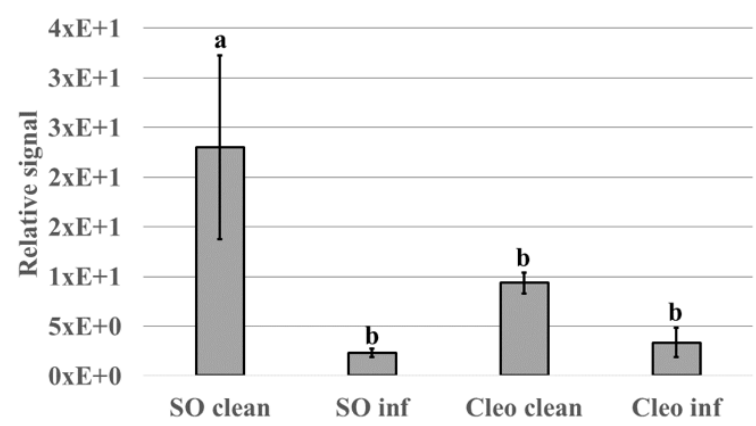

D

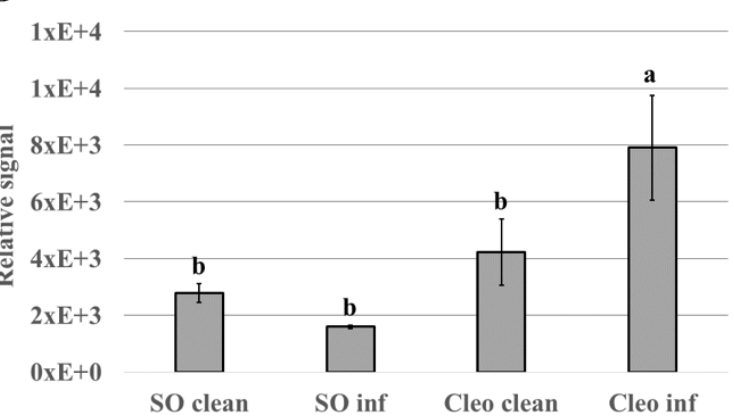

F

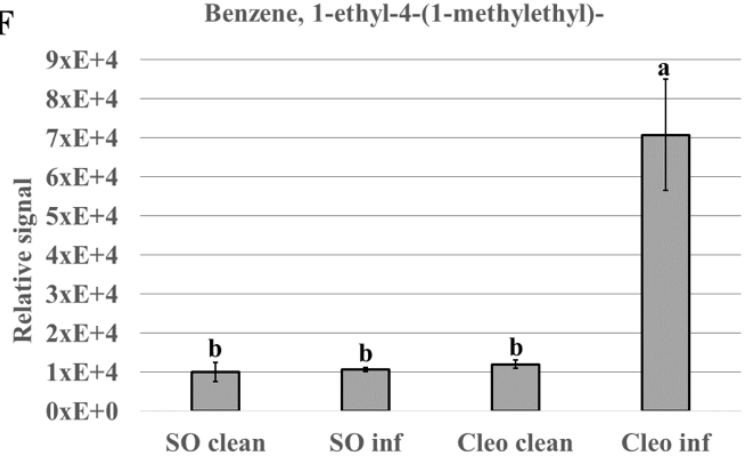

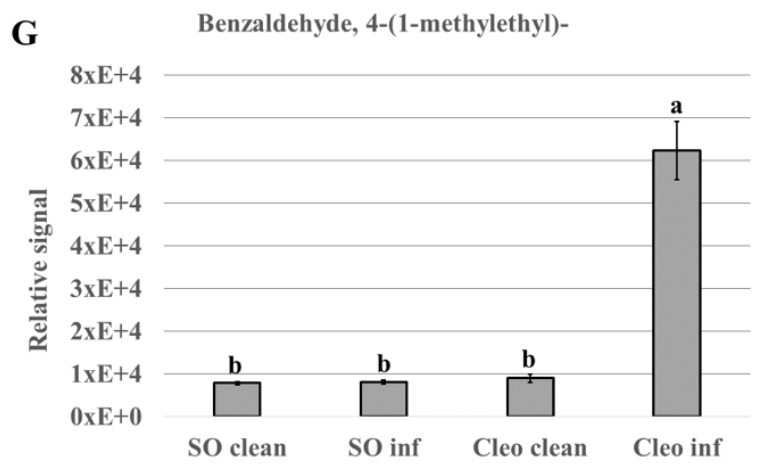

Figure 1.4 Relative signal (TOF-MS-derived peak areas) of the volatiles differentially produced in occupied (inf) and unoccupied sour orange (SO) and Cleopatra mandarin (Cleo) plants during the first 24 hours of occupiation with 25 E. stipulatus adult females. A. Pinene; B. Cineole; C. 1(2,5-dimethylphenyl)-Ethanone; D. 2,6,10-Dodecatrienoic acid; E. 1-methyl-4-(2-propenyl)Benzene; F. 1-ethyl-4-(1-methylethyl)-Benzene; G. 4-(1-methylethyl)-Benzaldehyde. For each figure, bars with the same letter are not significantly different $(P>0.05)$. 


\subsection{Discussion}

To our knowledge, this is the first study to demonstrate that zoophytophagous phytoseiid mites can trigger defensive responses in plants. The presence of E. stipulatus was perceived by the plant, which reacted to it in a genotype-dependent way, with sour orange exhibiting a stronger and more diversified response than Cleopatra mandarin. Although phytophagy remains the most likely trigger for these responses, other causes, including the physical presence of the predatory mite on the plant, its footsteps and its deposition of feces or eggs, cannot be discarded (Howe and Jander, 2008; Wu and Baldwin, 2010; Hilker and Fatouros, 2015). Direct plant feeding by the closely related phytoseiids Euseius scutalis (Athias-Henriot) and Iphiseius degenerans (Berlese) entails crimping and piercing the feeding surface (Adar et al., 2012). In the case of E. scutalis, plant cellsap uptake in pepper plants is performed by penetrating the leaf epidermis, leaving discrete holes in its surface surrounded by intact cells (Adar et al., 2015). This type of wounding is completely different from the injury produced by T. urticae. This herbivore uses its stylets to penetrate leaves, either in between epidermis pavement cells or through a stomatal opening, to feed from individual mesophyll cells without damaging the epidermal cell layer (Bensoussan et al., 2016). Assuming that E. stipulatus most likely produces a wounding similar to that described for E. scutalis, which also occurs in citrus in the Mediterranean, (Tanigoshi et al., 1990; Abd El-Samad et al., 1996; Vela et al., 2017) the plant responses expected after feeding would be different from those triggered by the tetranychid. These differences would be related to the targeted plant cell/tissue type. This was the case for Cleopatra mandarin but not for sour orange, where the defense pathways triggered by these two mite species were quite similar. On the one hand, the oxylipin pathway was upregulated in both citrus genotypes in a similar manner (Figure 1.3A), whereas for T. urticae occupation, this upregulation was observed in sour orange only (Agut et al., 2014). On the other hand, the SA (Figure 1.3B) and flavonoids (Figure 1.3C) pathways presented the same trends as observed for T. urticae occupation. As the response of sour orange is based on the simultaneous activation of different types of defense (JA, SA, flavonoids), our results confirm that this genotype may be a jack-of-alltrades, in which some well-known negative cross-talk mechanisms between signaling pathways in plant defense (i.e., JA-SA) do not occur (Agut et al., 2014; Pieterse et al., 2009; Robert-Seilaniantz et al., 2012). However, the solely upregulation of the JA pathway in Cleopatra mandarin may indicate that some of these negative cross-talks are 
functional in this genotype. The ability of sour orange to resist $T$. urticae was attributed in former studies to a combination of basal and inducible direct and indirect defense mechanisms (Agut et al., 2014). Direct mechanisms include high levels of flavonoids and a fast and effective activation of the JA signaling pathway (Agut et al., 2014). Because LOX proteins are a family of enzymes involved in the synthesis of JA that play important roles in the metabolic responses to wounding, (Howe and Jander, 2008; Farmer et al., 2014) we hypothesize that the activation of this pathway in both genotypes (Figure 1.3) may be a response to the wounding produced to epidermal cells by E. stipulatus. Such damage, as explained above, does not occur for T. urticae (Bensoussan et al., 2016). Although direct plant feeding by T. urticae (Agut et al., 2014) and presumably by $E$. stipulatus activated the same defensive pathways in sour orange, Pinene was the only common compound found in the HIPV blends elicited by these two mites (Agut et al., 2015), (Table 1.1). While Pinene was indicative of E. stipulatus occupation in both genotypes, for T. urticae this volatile was differentially produced upon occupation in sour orange, only (Agut et al., 2015). As a consequence, Pinene, together with 2,6,10Dodecatrienoic acid, 1-methyl-1-4-(2-propenyl)-Benzene, 1-ethyl-4-(1-methylethyl)Benzene, and 4-(1-methylethyl)-Benzaldehide, which followed similar increasing trends upon E. stipulatus occupation in Cleopatra mandarin (Figure 1.4), could be the key volatiles for the observed attraction of T. urticae for E. stipulatus-occupied plants (Figure 1.1). The result that pinene and 1-methyl-1-4-(2-propenyl)-benzene were the only volatiles which increased in sour orange upon occupation (Table 1.1; Figures 1.4A and 1.4E) could be taken as indicative of the crucial role of these two HIPVs. Whether $T$. urticae attraction could be the result of these volatiles masking E. stipulatus own odors deserves further research. Remarkably, the fact that upon T. urticae feeding, sour orange became repellent for conspecific mites (Agut et al., 2015), highlights the importance of considering the whole blend of volatiles and no single specific compounds when assessing this type of behavioral responses (Gregg et al., 2018).

With the exception of pinene, which was equally induced in E. stipulatus-occupied plants, the remaining HIPVs could be split in two groups: those which were higher in sour orange and decreased with occupation (cineole and 1-(2,5-dimethylphenyl) ethanone), and those which were higher in Cleopatra mandarin and increased with occupation (Table 1.1). These two groups most probably play an important role in the plant choices observed for this phytoseiid mite. Interestingly, most of the volatiles in the second group are aromatic 
compounds, which are related to the flavonoids pathway since both originate from the same precursors, including phenylalanine and its derivatives (Dudareva et al., 2013). However, the levels of most of these aromatic volatiles did not change in sour orange [1methyl-4-(2-propenyl) Benzene escaped to this trend and slightly increased, Figure 4E] while they increased in Cleopatra mandarin, just the opposite of what we observed for CHS gene expression (Figure 3C). This observation may be explained by the enhanced levels of flavonoids observed in sour orange following occupation by $T$. urticae, since this genotype seems more efficient in the biosynthesis of these flavonoid derivatives, such as naringenine, than Cleopatra mandarin (Agut et al., 2014). As the biosynthesis of the aromatic volatiles and flavonoids, which are directly related to direct defense, share a common origin, E. stipulatus could exploit these aromatic volatiles to select plants with relatively lower levels of direct defense (Figure 1.2).

The results of the olfactometer assays only partially match our initial hypotheses. In the case of T. urticae and in agreement with them, it was repelled by the odor of its potential predator and it chose less defended unoccupied Cleopatra mandarin rather than unoccupied sour orange (Figure 1.1). However, the forecasted over-ruling of its predator associated odors (including E. stipulatus-triggered HIPVs) leading to repellence proved wrong. In the case of E. stipulatus, in agreement with our hypotheses, the phytoseiid always chose the plants producing higher levels of aromatic volatiles (Figures 1.2 and 1.4), which according to what we exposed in the previous paragraph, could be perceived as those containing less flavonoids. However, this mite was attracted by conspecifics and the over-ruling of the odors associated with its presence on the plant proved wrong as well. On the one hand, these failures may be the result of these two mites making decisions based not only on volatiles but refined later on with tactile stimuli, both chemical and physical, on the surface of the host plant, which could change the sign of the attraction (Müller and Riederer, 2005; Schmidt, 2014). On the other hand, they may be a consequence of E. stipulatus posing a relatively low predation/cannibalism risk to $T$. urticae and conspecific hungry adult females, respectively. In a field study where $E$. stipulatus was subjected to gut-content analysis, Pérez-Sayas et al. (2015) demonstrated that this phytoseiid significantly preferred non-tetranychid food sources over both $T$. urticae and $P$. citri, independently of the densities of these two tetranychid prey species. Indeed, only $28.4 \%$ of the individuals analyzed proved positive for $T$. urticae feeding, 
whereas this figure increased to $75.7 \%$ for the co-occurring Tetranychus spp. specialist predator Phytoseiulus persimilis (Athias-Henriot).

\subsection{Conclusion}

Although the net effects of the interactions described herein for herbivore pest populations should be assessed in the field under more realistic conditions, our results prove that zoophytophagous phytoseiid mites may affect their prey beyond predation through plant-mediated effects. The characterization of such effects may help refining current biological control practices. Because the HIPV blends identified in this study proved to effectively attract $T$. urticae and E. stipulatus, opportunities for the exploitation of these semiochemicals to increase the efficacy of biological control exist and should be explored. 



\section{CAPÍTULO 2}

Non-feeding activities of predatory phytoseiid mites can trigger plant defense responses in citrus altering the behavior of conspecifics and potential prey

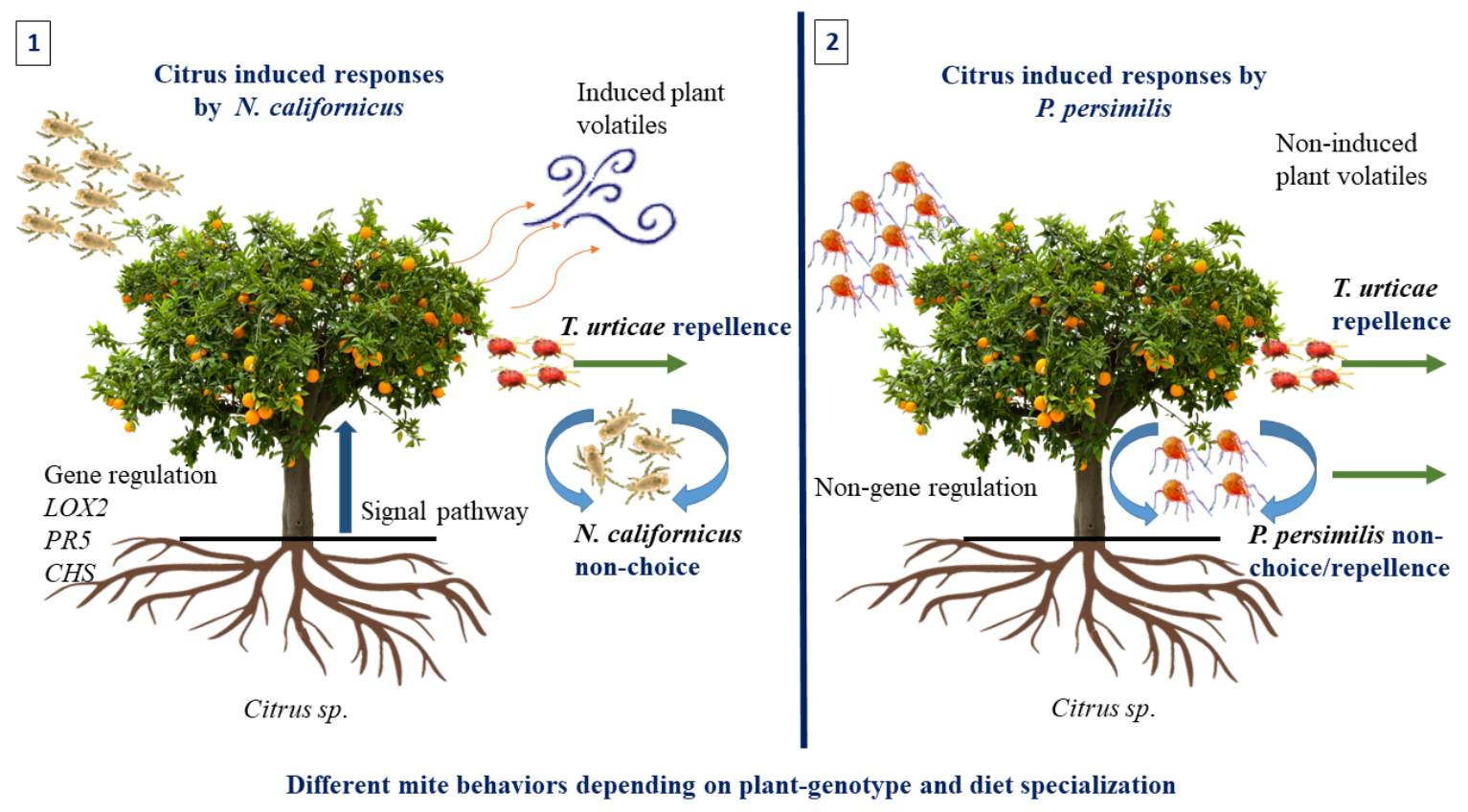

A version of this chapter has been submitted for publication:

Joaquín Cruz-Miralles, Marc Cabedo-López, Meritxell Pérez-Hedo, Víctor

Flors and Josep A. Jaques 



\begin{abstract}
Zoophytophagous arthropods can elicit plant defense responses affecting potential prey beyond predation. Plant feeding prevails as the cause for these responses. This is the case of Euseius stipulatus, a plant cell-sap feeding predator. However, other triggers not related to feeding cannot be excluded. The aim of our study was to examine whether nonplant feeding phytoseiid predators can induce such responses.

We have characterized plant response (volatile metabolome and gene expression) to two phytoseiids that do not engage in plant-cell feeding and co-occur with E. stipulatus (Neoseiulus californicus and Phytoseiulus persimilis) in Spanish citrus orchards. We have further studied the behavior of these phytoseiids and their shared prey, Tetranychus urticae, to phytoseiid-occupied plants.

Different volatile blends were produced by plants upon exposure to $N$. californicus, whereas $P$. persimilis did not elicit any change in the plant. These results corresponded to $N$. californicus triggering plant genotype-dependent defense responses as a consequence of plants perceiving non-feeding activities of this mite.

The shared prey T. urticae avoided well protected plants, either because of stronger bottom-up (i.e., plant basal and inducible) or top-down (i.e., predator presence) defenses., Because plants with weak direct defense levels should offer higher prey densities, and those occupied by conspecifics represent higher risk of cannibalism, predators were expected to behave similarly. However, they preferred plants with stronger direct defense levels. Moreover, choices where conspecifics were included depended on plant genotype. Our results demonstrate for the first time that phytoseiid non-feeding activities may trigger plant defense responses that may affect herbivores beyond predation.
\end{abstract}

Keywords: HIPV, induced plant defense, Neoseiulus californicus, Phytoseiulus persimilis, spider mites, Tetranychus urticae 



\subsection{Introduction}

Cruz-Miralles et al. (2019) recently demonstrated that, similar to some zoophytophagous insects (Arnó et al., 2009; De Puysseleyr et al., 2011; Perdikis et al., 2011; Messelink et al., 2015; Pappas et al., 2015; Pérez-Hedo et al., 2015; Bouagga et al., 2018; Zhang et al., 2018), zoophytophagous phytoseiid mites can trigger plant defense responses. The omnivore predator Euseius stipulatus (Athias-Henriot) (Acari: Mesostigmata), the most abundant phytoseiid mite in Spanish citrus orchards (Aguilar-Fenollosa et al., 2011a; Vela et al., 2017), can elicit genotype-dependent defense responses in Citrus spp., which may affect its potential prey, mostly the herbivorous tetranychid mites Tetranychus urticae Koch and Panonychus citri McGregor (Acari: Prostigmata) (Ferragut et al., 1988; Pérez-Sayas et al, 2015), beyond predation. Indeed, the Jasmonic Acid (SA), the Salicylic Acid (SA), and the flavonoids defense pathways were upregulated in sour orange, Citrus aurantium L., in response to E. stipulatus while JA was upregulated and flavonoids were downregulated in Cleopatra mandarin, C. reshni Hort. ex Tan., when exposed to this phytoseiid (Cruz-Miralles et al., 2019). These two Citrus species, which can be used as commercial rootstocks in citrus production, had been chosen because of their extreme resistance and susceptibility to T. urticae, respectively (Bruessow et al., 2010; Agut et al., 2014), which is transmitted from the roots to the grafted cultivar (Agut et al., 2016). This herbivore is considered a key pest of Spanish clementine mandarin orchards (PascualRuiz et al., 2014). Resistance to T. urticae in sour orange is the result of a combination of (1) higher basal and (2) faster and stronger inducible defense upon T. urticae attack than in Cleopatra mandarin and mostly relies on the JA defense pathway (Agut et al., 2014). Different volatile blends (herbivore induced plant volatiles, HIPVs) were also induced in these Citrus species when exposed to E. stipulatus. These blends were exploited by $E$. stipulatus to select less defended plants (i.e., occupied Cleopatra mandarin rather than sour orange), where higher prey densities are expected, and did not inhibit T. urticae from choosing E. stipulatus-occupied plants. Remarkably, in the same study the odors of $E$. stipulatus alone proved repellent to T. urticae, which highlights the importance of these HIPVs for the predator to remain unnoticed by its prey.

Although phytophagy prevails as the most likely cause for the observed responses, and this is why the blends induced by E. stipulatus are qualified as HIPVs (Cruz-Miralles et al., 2019), other potential triggers related to presence of the predatory mites on plants (e.g. footsteps, presence of predator, eggs or feces) cannot be excluded (Howe and Jander, 
2008; Wu and Baldwin, 2010; Hilker and Meiners, 2010; Hilker and Fatouros, 2015; Schuman and Baldwin, 2016). Indeed, E. stipulatus is an extreme diet generalist, a true omnivore that feeds on both animal and plant derived food, for which plant cell-sap feeding is assumed to occur (Adar et al., 2012) as it is a common behavior in the genus Euseius De Leon (McMurtry et al., 2013).

In Spanish citrus orchards, E. stipulatus co-occurs with other phytoseiid species (AguilarFenollosa et al., 2011a; Vela et al., 2017). Among them, Neoseiulus californicus (McGregor) can also feed on both prey and plant derived food (i.e., pollen) (McMurtry and Croft, 1997; McMurtry et al., 2013). However, contrary to E. stipulatus, N. californicus is not a plant cell-sap feeding phytoseiid (Adar et al., 2012). Phytoseiulus persimilis (Athias-Henriot) also co-exists with the former two. This is a Tetranychusspecialist predator that does not feed on plants (Magalhães and Bakker, 2002). These diet specializations offer the opportunity to check whether plant responses to E. stipulatus observed in citrus are widespread among phytoseiids, and therefore, are not exclusively triggered by herbivory. Moreover, this system also allows to check whether $N$. californicus and P. persimilis select the two aforementioned Citrus species in a similar way than E. stipulatus. Although, as pointed out earlier, predators would benefit from choosing less defended plants (i.e., Cleopatra mandarin) as indicative of higher prey densities, in non-feeding plant cell-sap mites that cannot switch to plant feeding when prey is scarce, strong attraction for these plants could be missing. Our initial hypothesis is that neither $N$. californicus nor $P$. persimilis will trigger any plant defense response because we presume that they do not produce any feeding-related injury to plants. Therefore, both predators should be attracted to less defended plants where prey density is high (i.e., Cleopatra mandarin, where basal defense against T. urticae is lower). Moreover, an over-ruling of phytoseiid odors would result in both prey and predators preferring clean versus phytoseiid-occupied plants to avoid predation/cannibalism risk. Should our hypotheses prove wrong, this would mean that plants can perceive not only the injury made by cell-sap feeding phytoseiids (i.e., E. stipulatus) but also their presence or their non-feeding activities (i.e., walking, oviposition, excretion). This could further affect the whole community through plant-mediated effects. To achieve this goal, we have characterized the behavior of T. urticae, N. californicus, and P. persimilis in different two-choice olfactory tests where they had to choose between different odor sources including the two phytoseiid species and phytoseiid-occupied citrus plants. We have 
further characterized the volatile blends produced by these plants when exposed to the phytoseiids and, lastly, the genetic changes in their main defensive pathways.

\subsection{Materials and methods}

\subsubsection{Plant material}

Three-month-old pesticide-free sour orange and Cleopatra mandarin plants were grown on vermiculite and peat in 320-ml pots in a climatic chamber following the same methods as in previous work (Cruz-Miralles et al., 2019): $22 \pm 5^{\circ} \mathrm{C} ; 60 \pm 10 \% \mathrm{RH}$ and 16:8 h L:D photoperiod. The same conditions were used for mite rearing and the assays below. Pesticide-free lemons and bean plants (Phaseolus vulgaris L. cv. Buenos Aires roja) produced at UJI Campus were used to maintain T. urticae and P. persimilis colonies, respectively.

\subsubsection{Spider mite stock colony}

This colony was initiated with specimens collected in clementine orchards in the region of La Plana (municipality of Les Alqueries, UTM: 3959'15.1"N 0³'02.0"W) in 2001. To avoid maternal effects that could affect risk perception (Freinschlag and Schausberger, 2016), spider mites were maintained on lemons following Cruz-Miralles et al. (2019). The preferences of adult females obtained from this colony to different odor sources was determined in Y-tube olfactory choice assays (see below). Prior to their use, females were subjected to 24-h starvation inside $50 \mathrm{ml}$ plastic vials where mites in groups of 15 could drink on a water-soaked cotton ball.

\subsubsection{Neoseiulus californicus stock colony}

Neoseiulus californicus was obtained from Koppert Biological Systems (SPICAL $®$ ). Adult females were removed from the rearing substrate with a soft-bristle paintbrush and moved individually to an arena consisting of a thin black plastic board $(9.5 \mathrm{~cm}$ diameter) placed on top of a water-saturated foam cube (3-4 cm thick) in an open plastic box $(20 \times$ $15 \times 4 \mathrm{~cm} 3$ ) half-filled with water to prevent mites escaping from the arena. These females were further used in the Y-tube olfactory choice tests (see below) either to determine their preferences or as an odor source. In the former case, same as T. urticae, females were 
subjected to starvation prior to use. When used as an odor source, 25 adult females were either deposited on different leaves of the same plant using a soft-bristle paintbrush, or moved to a meshed bag $(10 \times 5 \mathrm{~cm})$ closed with a magnet. To prevent ambulatory mite movement between plants, pots were isolated from each other by singly setting them in $14 \times 14 \times 7 \mathrm{~cm}$, placed inside a larger tray filled with water. Occupied plants remained in a climatic chamber for up to 48 hours before use. Plants were grouped by both genotype and occupation status, and groups were kept isolated to avoid any exposure to plant volatiles from the other treatments, which could induce undesired defensive responses (Agut et al., 2015).

\subsubsection{Phytoseiulus persimilis stock colony}

This colony was initiated with specimens collected in 2012 at the same location as $T$. urticae. The rearing was set on detached leaf units consisting of a single bean leaf using standard procedures as detailed in Cruz-Miralles et al. (2019) for E. stipulatus. A mix of different stages of $T$. urticae was provided twice a week to feed $P$. persimilis. Same as before, females were used in the Y-tube olfactory choice tests as either an odor source (with or without plant) or subjected to a 24-h starvation period before studying their preferences.

\subsubsection{Y-tube olfactory choice assays}

We used a Y-tube olfactometer (Bruin et al., 1992) following the same procedure as in previous work (Agut et al., 2015; Cruz-Miralles et al., 2019). Starved adult females were individually deposited at the beginning of the long arm of the Y-wire using a soft-bristle paintbrush. They were allowed during $10 \mathrm{~min}$ to make a choice between two odours coming from glass vessels containing different odor sources (young plants with or without phytoseiid mites, mites, or nothing). As soon as a mite reached the end of one arm, it was removed and discarded. Mites failing to reach either end of the arms within 10 min were scored as 'no choice'. Two-choice experiments involving the two phytoseiids ( $N$. californicus or P. persimilis), sour orange and Cleopatra mandarin plants either clean or phytoseiid-occupied, were performed. After five females had been tested, the glass vessels were switched to reduce the effects of spatial influence on choice. After every 10 females had been tested, the odor sources (i.e., the plants) were replaced and the whole 
system was rinsed with ethanol (70\%), followed by drying air. Four replicates of 10 responding mites per choice combination were considered. These replicates were run at different dates. To exclude any bias from the set-up, before the beginning of the assays, 10 mites were exposed to clean air in both arms. A random response was expected.

\subsubsection{Collection of headspace volatiles in plants}

Volatiles from the two aforementioned Citrus species, including clean and $N$. californicus and $P$. persimilis-occupied plants, were collected using a headspace collection system following standard procedures in our group (Agut et al., 2015; Cruz-Miralles et al., 2019). In short, 5-1 glass vessels (Duran, Mainz, Germany) ventilated with carbon-filtered pressure-air at $1.51 \mathrm{~h}-1$ were used. Pasteur pipettes with $300 \mathrm{mg}$ of Porapak (SigmaAldrich, Barcelona, Spain) were used as a volatile retention filter. Plants were individually introduced into the glass vessels. The system (glass vessels and Porapak filters) was cleaned with acetone and dried in an oven 1 hour prior to the assay. Collection took place in a climatic chamber at the same environmental conditions used to grow the plants. When necessary, 25 adult females per plant were transferred as explained above. These females could oviposit, excrete, cannibalize, or try to escape. Volatiles were collected in $1 \mathrm{ml}$ of ethyl acetate during the following 24 hours. Three plants per genotype and infestation status were considered in each of the three replicates of this assay.

\subsubsection{Gas chromatography (GC) instrumentation}

Same as before, following standard procedures in our group (Agut et al., 2015; CruzMiralles et al., 2019), an Agilent 6890N GC system (Palo-Alto, CA, USA), equipped with an Agilent 7683 autosampler, coupled to a time-of-flight mass spectrometer (TOF-MS), GCT (Waters Corp., Manchester, UK), operating in electron ionization (EI) mode were used. A fused silica DB-5MS capillary column of $30 \mathrm{~m}$ length, $0.25 \mathrm{~mm}$ internal diameter and a film thickness of $0.25 \mathrm{~m}$ (J\&W Scientific, Folson, CA, USA) were used for GC separation. The temperature program for this process was the following; $50^{\circ} \mathrm{C}(1 \mathrm{~min})$; $5^{\circ} \mathrm{C} \mathrm{min}^{-1}$ to $210^{\circ} \mathrm{C}(1 \mathrm{~min}) ; 20^{\circ} \mathrm{C} \mathrm{min}^{-1}$ to $300^{\circ} \mathrm{C}$ ( $\left.2 \mathrm{~min}\right)$; this resulted in a total analysis run of $40.50 \mathrm{~min}$. Splitless injections were carried out. Helium was used as carried gas at $1 \mathrm{ml} \mathrm{min}-1$.The interface and source temperatures were both set to $250^{\circ} \mathrm{C}$ and a solvent delay of 3 min was selected. The TOF-MS was operated at 1 spectrum s$^{-1}$ acquiring the 
mass range $\mathrm{m} / \mathrm{z} 50-650$ and using a multi-channel plate voltage of $2800 \mathrm{~V}$. The TOF-MS resolution was c. 8500 (full width at half-maximum, FWHM) at m/z 614. Heptacose, used for the daily mass calibration as well as lock mass, was injected via syringe into the reference reservoir at $30^{\circ} \mathrm{C}$. The $\mathrm{m} / \mathrm{z}$ ion monitored was 218.9856 . The application manager ChromaLynx, a module of MassLynx software, was used to investigate the presence of non-target compounds in the samples.

Volatile compounds were tentatively identified using GC-MS and matching to the National Institute of Standards and Technology (NIST $\backslash E P A \backslash N I H$ Mass Spectral Library, version 2.0, build 4/2005) using match values of at least 850 as a threshold for identification, as described by Wallis et al. (2008). Furthermore, for each HIPV identified the TOF-MS-derived peak areas were calculated and used to estimate their relative concentration.

Only when a different volatile profile between clean and phytoseiid-occupied plants was detected, genetic characterization was undertaken. The reason being that HIPV production largely depends on changes in the regulation of plant defensive pathways (Howe and Jander, 2008)

\subsubsection{Quantitative real-time reverse transcription-polymerase chain reaction (qRT- PCR) analysis in plants occupied by phytoseiids}

For each phytoseiid species under consideration, three assays including 3 plants per treatment were carried out. For each assay, six sour orange and six Cleopatra mandarin plants were used. Three out of these six plants were occupied with the phytoseiid as previously explained, whereas the other three remained unoccupied and were used as control. 48 hours after occupation at the same temperature and RH conditions as before, leaves were cut and immediately introduced into $50 \mathrm{ml}$ Falcon vials, which were immersed in liquid nitrogen and stored at $-80^{\circ} \mathrm{C}$ until extraction. Leaves from the same treatment were pulled together in the same vial. Following standard procedures used in our group (Agut et al., 2015; Cruz-Miralles et al., 2019), RNA was extracted using a Plant RNA protocol with trizol. The expression of lipoxygenase 2 ( $L O X 2$; accession Cit.16756.1.S1_sat; forward primer: 5' $\rightarrow$ 3' GAACCATATTGCCACTTTCG; reverse primer 5' $\rightarrow$ 3': CGTCATCAATGACTTGACCA) pathogenesis-related protein 5 (PR5; accession BAI63297.1; forward primer: 5' $\rightarrow$ 3' CATCAAGCTTCACAGTGCTTAG; 
reverse primer 5' $\rightarrow 3^{\prime}:$ CCACAACGTACAGACTGATGAC) and chalcone synthase (CHS; accession CF417078; forward primer: 5' $\rightarrow$ 3': AGACGATCCTCCCTGACTCT; reverse primer 5' $\rightarrow$ 3': CTCCACTTGGTCCAGAATTG) genes was determined. Relative expression was compared with the housekeeping gene glyceraldehyde 3-phosphate dehydrogenase (GAPDH; accession Cit.122.1; forward primer: 5' $\rightarrow$ ': GGAAGGTCAAGATCGGAATCAA; reverse primer $\quad 5$ ' $\rightarrow$ ': CGTCCCTCTGCAAGATGACTCT).

\subsection{Results}

\subsubsection{The presence of either $N$. californicus or $P$. persimilis in citrus plants modifies the behavior of conspecifics and also of their potential prey $T$. urticae}

To check whether our initial hypotheses that (1) N. californicus and P. persimilis would be attracted to less defended plants and that (2) an over-ruling of phytoseiid odors would result in all three mite species preferring clean versus phytoseiid-occupied plants, we performed a series of 2-choice tests. Results of each preference test were initially subjected to logistic regression to check for the effect of replicate $(n=4)$ on mite preference. Because this effect was not significant $(P>0.05)$ in any case, the results of the four replicates per choice test were pooled and subjected to chi-square analysis to test whether they departed from a 1:1 distribution. IBM SPSS Statistics 23 was used. On the one hand, and in agreement with both hypotheses, T. urticae adult females selected less defended plants (clean Cleopatra mandarin) (Figure 2.1a) and were similarly repelled by either N. californicus (Figure 2.1b) or P. persimilis (Figure 2.1c) regardless of whether these predators were alone or occupying the plants. As Cleopatra mandarin was preferred over sour orange when both plants were unoccupied but no preference was observed when they were occupied by any of the phytoseiids, these results can be taken as evidence of the over-ruling of phytoseiid-related odors for host selection by T. urticae. On the other hand, none of the phytoseiids chose Cleopatra plants but better protected sour orange when both species were unoccupied (Figures 2.2a and 2.2b). Further, none of them were attracted to conspecifics. However, while P. persimilis did not show any preference between clean air and conspecific odors, N. californicus preferred clean air. No overruling of conspecific odors, though, was observed for $N$. californicus, which did not show any preference in any of the three combinations including conspecific-occupied plants (Figure 2.2a). On the contrary, when P. persimilis had to choose between unoccupied and 
conspecific-occupied plants, choice depended on plant genotype. When both Citrus species were occupied, a preference for Cleopatra mandarin was observed. Same as with T. urticae, these contrasting choices observed in the two genotypes depending on occupation can be taken as evidence of the importance of the interaction between plant and mite-associated odors for triggering ambulatory responses in these phytoseiids.

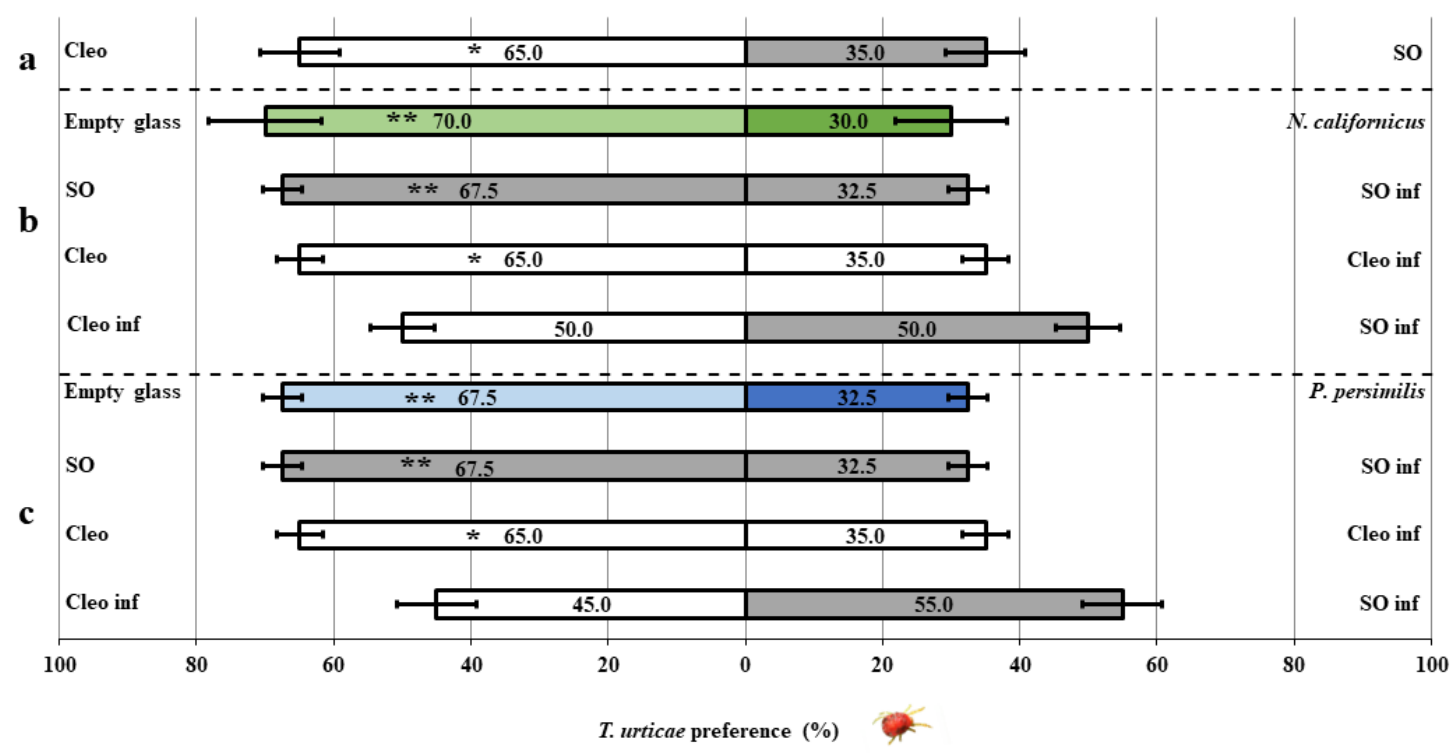

Figure 2.1 Olfactory responses of $T$. urticae adult females to $N$. californicus and $P$. persimilis. Nine different combinations, in which $T$. urticae had to choose between two odor sources, were tested. A minimum of 40 adult females per choice combination was tested. From top to bottom these combinations were: (a) Cleopatra mandarin control plants (Cleo) vs sour orange control plants (SO), (b) N. californicus and (c) P. persimilis. For each phytoseiid, the following four combinations were considered: empty glass versus the phytoseiid, SO vs SO-occupied plants (SO inf), Cleo vs Cleo-occupied plants (Cleo inf), and Cleo inf vs SO inf. Occupied plants had been exposed to 25 phytoseiid adult females for $48 \mathrm{~h}$ before the onset of the assay. Asterisks indicate significant differences from a 1:1 distribution (one asterisk: chi-square test $P<0.10$, two asterisks: chi-square test $P<0.05$ ). 

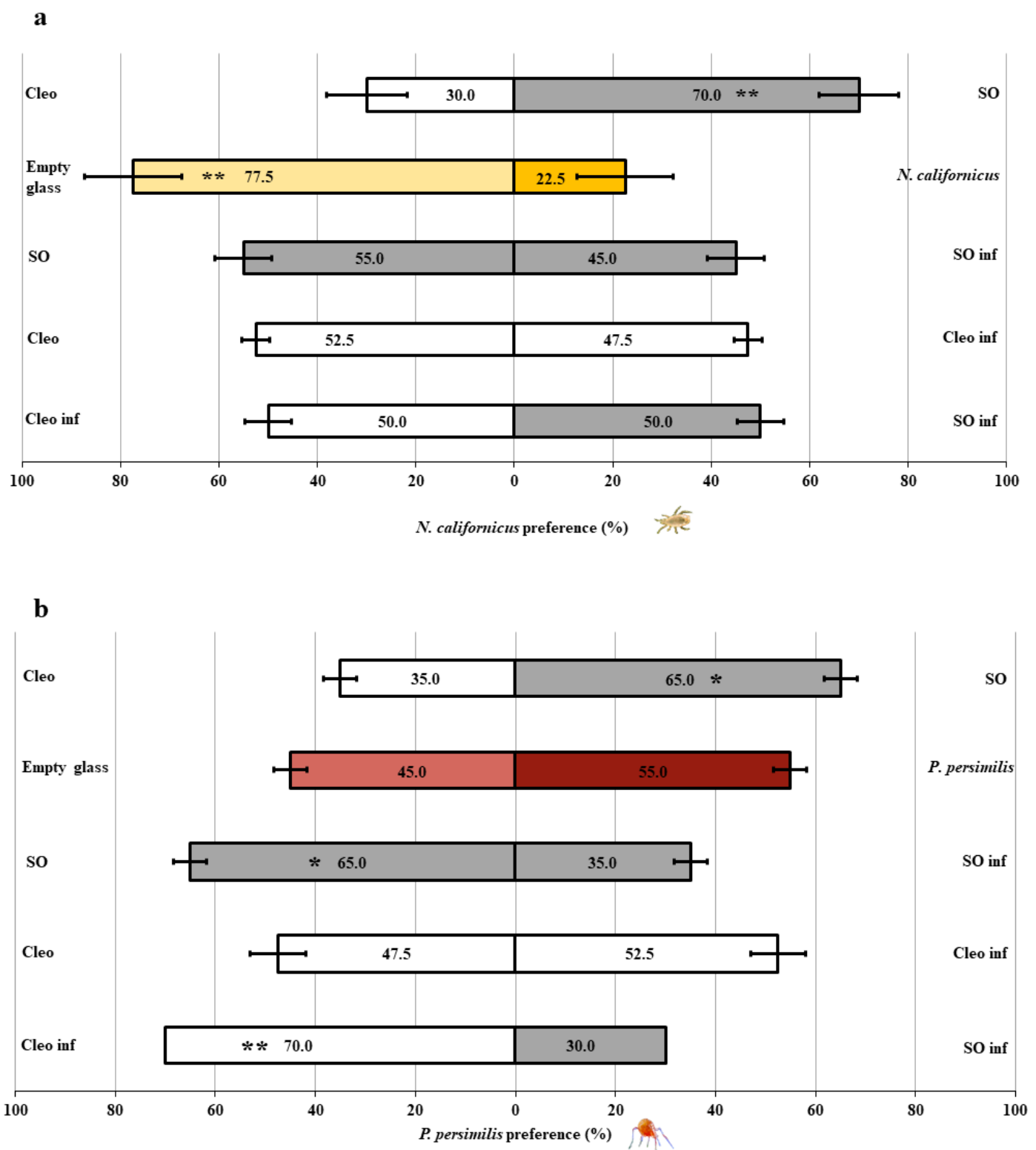

Figure 2.2 Olfactory responses of (a) $N$. californicus and (b) P. persimilis adult females to conspecific mites. For each phytoseiid, five different combinations, in which the phytoseiid had to choose between two odor sources, were tested. A minimum of 40 adult females per choice combination was tested. From top to bottom these combinations were: Cleopatra mandarin control plants (Cleo) vs sour orange control plants (SO), empty glass versus the phytoseiid, SO vs SOoccupied plants (SO inf), Cleo vs Cleo-occupied plants (Cleo inf), and Cleo inf vs SO inf. Occupied plants had been exposed to 25 phytoseiid adult females for $48 \mathrm{~h}$ before the onset of the assay. Asterisks indicate significant differences from a 1:1 distribution (one asterisk: chi-square test $P<0.10$, two asterisks: chi-square test $P<0.05$ ). 
2.3.2 The omnivorous predator $N$. californicus but not the strict entomophagous $P$. persimilis triggers the production of volatiles in sour orange and Cleopatra mandarin plants

When the volatile metabolome of phytoseiid-occupied relative to clean plants was characterized, we found no differences for $P$. persimilis whereas $N$. californicus generated different blends depending on the Citrus species considered. For each of the 10 compounds differentially produced upon exposure to N. californicus, TOF-MS-derived peak areas were compared using a Generalized Linear Model (GLM) with a normal distribution of the error and linear link function. Plant genotype, occupation status, and replicate were used as fixed effects. When necessary, we used Bonferroni post-hoc test $(P<0.05)$ for mean separation. The factor replicate was significant in eight out of the 10 volatiles, with Benzaldehyde and 6-benzyloxy-3,4-dihydro-4,4-dimethyl-Coumarin escaping to this trend (Table 2.1). However, as the relative differences observed for the other two factors considered (plant genotype and occupation) were consistent for each volatile (Figure 2.3), results were interpreted in a qualitative manner and according to these two factors only. Seven compounds were observed in one Citrus species only. Two of them appeared in Cleopatra mandarin only and did not change with occupation: 2methyl-3-heptanone (Figure 2.2a) and bezaldehyde (Figure 2.2b). 6-benzoyloxy-3,4dimethyl-coumarin (Figure 2.2c) and 1-ethyl-3-(1-methylethyl)-benzene (Figure 2.2d) followed the same trend in sour orange. 1,4-diethyl-benzene (Figure 2.2e) and 1,15pentadecanedioic acid (Figure 2.2f) increased in sour orange with occupation, whereas 1,2-benzisothiazole (Figure 2.2g) decreased in the same genotype. The remaining three compounds: cineole (Figure 2.2h), 1-phenyl-1-hexanone (Figure 2.2i), and 3,4dimethylbezamide (Figure 2.2j) were higher in sour orange and increased with occupation.
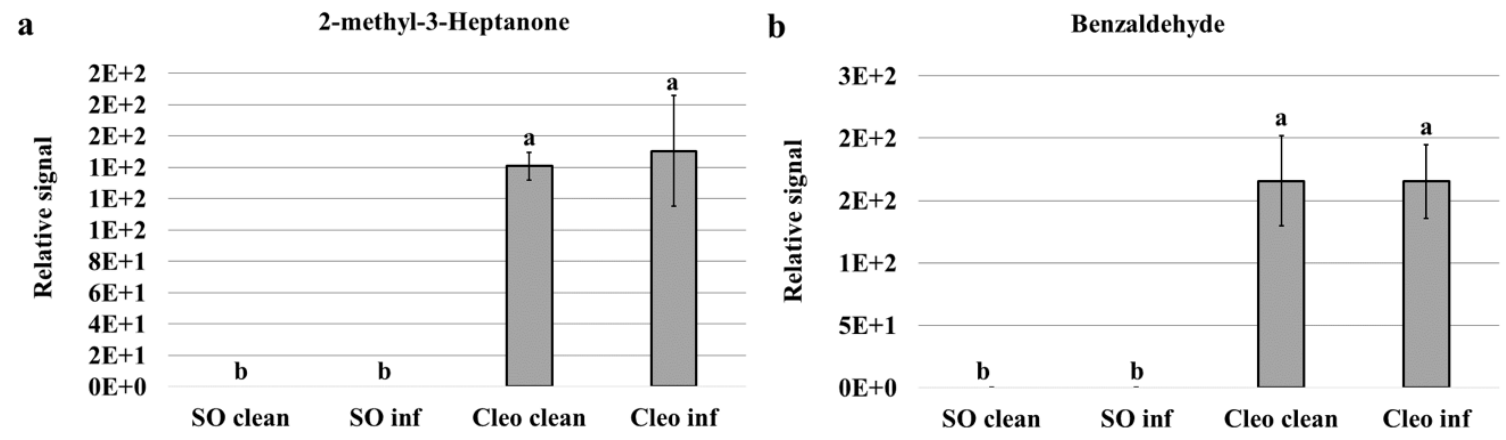
c

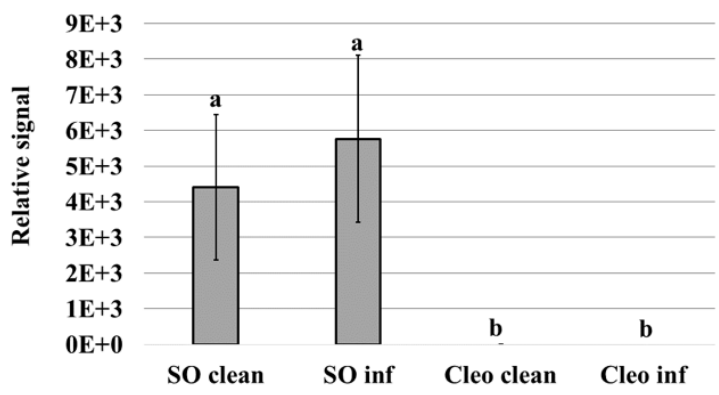

e

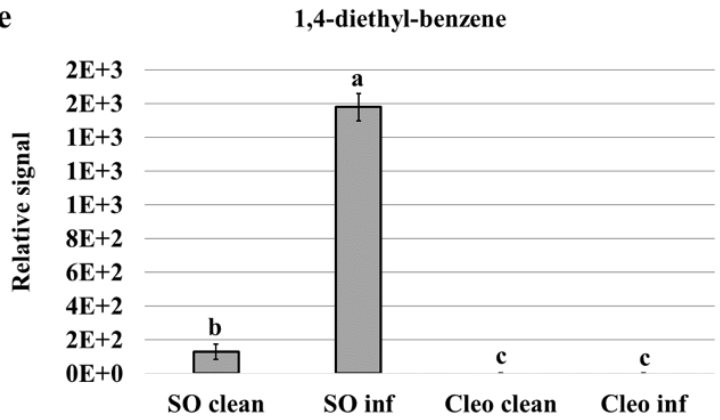

g

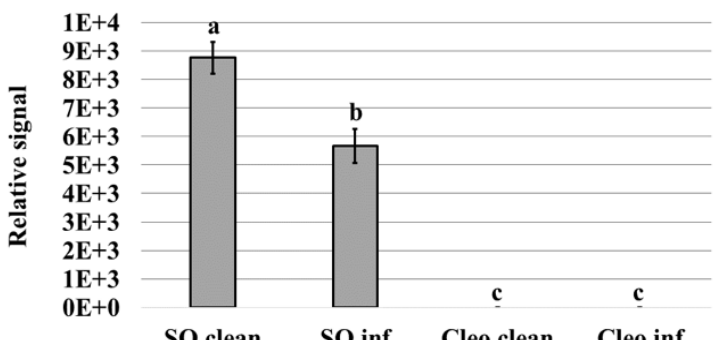

i

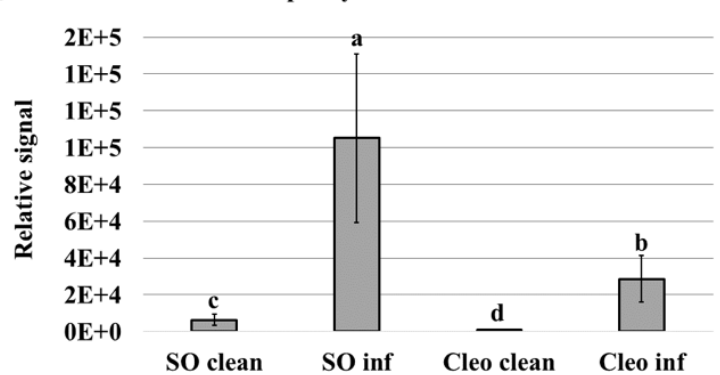

d

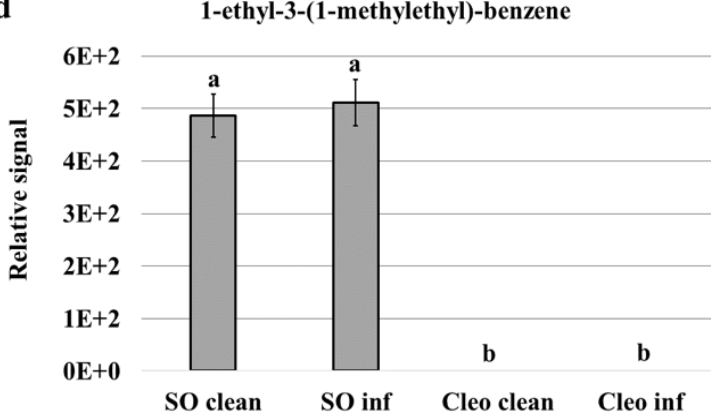

f

$4 \mathrm{E}+3$

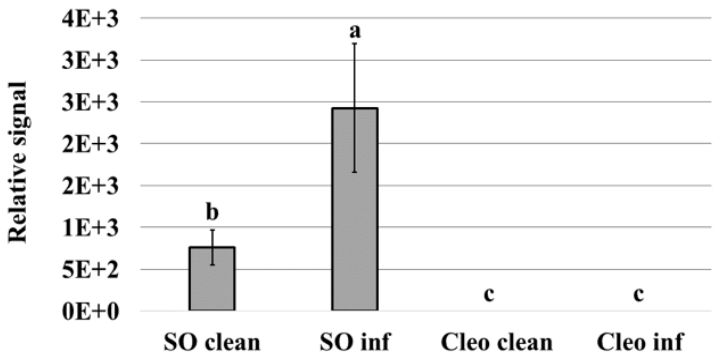

h

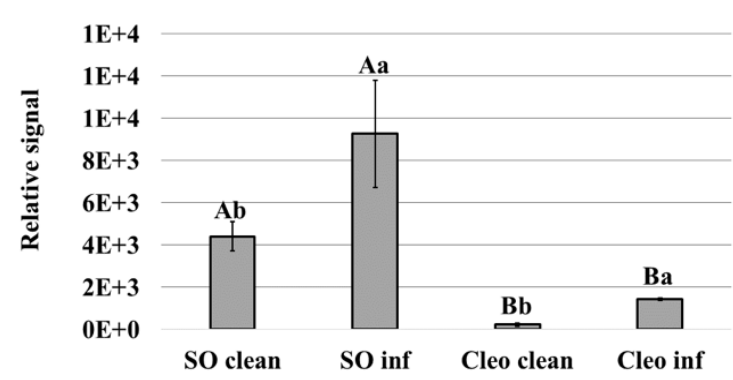

j

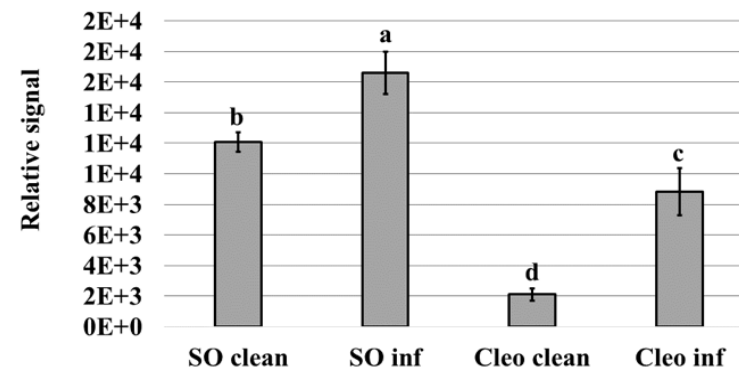

Figure 2.3 Relative signal (TOF-MS-derived peak areas) of the volatiles differentially produced in occupied (inf) and unoccupied (clean) sour orange (SO) and Cleopatra mandarin (Cleo) plants during the first 24 hours of occupation with $25 \mathrm{~N}$. californicus adult females. (a) 2-methyl-3Heptanone; (b) Benzaldehyde; (c) 6-benzyloxy-3,4-dihydro-4,4-dimethyl-Coumarin; (d) 1-ethyl3-(1-methylethyl)-benzene; (e) 1,4-diethyl-benzene; (f) 1,15-Pentadecanedioic acid; (g) 1,2Benzisothiazole; (h) Cineole; (i) 1-phenyl-1-Hexanone; (j) 3,4-Dimethylbenzamide. For each figure, bars with the same letter/s are not significantly different $(P>0.05)$. When the interaction between genotype and occupation was significant (Table 2.1), uppercase letters refer to genotype and lowercase to occupation. 
Table 2.1 Volatile profiling in the headspace of sour orange (SO) and Cleopatra mandarin (Cleo) plants either unoccupied (clean) or occupied (inf). For each volatile, TOF-MS-derived peak areas were compared using a Generalized Linear Model. Plant genotype, occupation status, and replicate were used as fixed effects. As either or both replicate and the interactions including this factor were significant $(P<0.05)$ in all cases except for 6-benzyloxy-3,4-dihydro-4,4-dimethylCoumarin and benzaldehyde, these results are not presented in the table. Because the relative differences observed for the other two factors considered were consistent for each volatile, results were interpreted in a qualitative manner and according to these two factors only. Volatiles were tentatively identified by comparing to the National Institute of Standards and Technology (NIST) Library as described by Wallis et al. (2008).

\begin{tabular}{|c|c|c|c|}
\hline \multirow[b]{2}{*}{ Volatile compounds } & \multicolumn{3}{|c|}{ GLM results $^{1}\left(\right.$ Wald- $\left.\chi^{2} ; P\right)$} \\
\hline & $\begin{array}{c}\text { Plant genotype } \\
\text { (A) }\end{array}$ & $\begin{array}{l}\text { Occupation } \\
\text { status (B) }\end{array}$ & $\mathbf{A} * \mathbf{B}$ \\
\hline 6-benzyloxy-3,4-dihydro- & $123.31 ;<0.001$ & $1.45 ; 0.228$ & $1.45 ; 0.228$ \\
\hline 4,4-dimethyl-Coumarin & $\mathrm{SO}>\mathrm{Cleo}=0$ & clean $=$ inf & \\
\hline Cineole & $\begin{array}{c}174.29 ;<0.001 \\
\mathrm{SO}>\text { Cleo }\end{array}$ & $\begin{array}{l}4.33 ; 0.037 \\
\text { clean }<\text { inf }\end{array}$ & $1.21 ; 0.272$ \\
\hline 1-phenyl-1-Hexanone & $\begin{array}{c}105.25 ;<0.001 \\
\mathrm{SO}>\text { Cleo }\end{array}$ & $\begin{aligned} 251.24 ; & <0.001 \\
\text { clean } & <\inf \end{aligned}$ & $\begin{array}{c}79.16 ;<0.001 \\
\text { SO inf }>\text { Cleo inf }>\text { SO clean }>\text { Cleo clean }\end{array}$ \\
\hline 1,4-diethyl-benzene & $\begin{array}{l}98.94 ;<0.001 \\
\mathrm{SO}>\mathrm{Cleo}=0\end{array}$ & $\begin{array}{c}50.88 ;<0.001 \\
\text { clean }<\text { inf }\end{array}$ & $\begin{array}{c}50.88 ;<0.001 \\
\text { SO inf }>\text { SO clean }>\text { Cleo inf }=\text { Cleo clean }\end{array}$ \\
\hline $\begin{array}{l}\text { 1-ethyl-3-(1-methylethyl)- } \\
\text { benzene }\end{array}$ & $\begin{array}{l}283.96 ;<0.001 \\
\mathrm{SO}>\text { Cleo }=0\end{array}$ & $\begin{array}{l}0.50 ; 0.481 \\
\text { clean }=\text { inf }\end{array}$ & $0.50 ; 0.481$ \\
\hline 1,2-Benzisothiazole & $\begin{array}{l}760.55 ;<0.001 \\
\mathrm{SO}>\mathrm{Cleo}=0\end{array}$ & $\begin{array}{l}4.28 ; 0.039 \\
\text { clean }>\text { inf }\end{array}$ & $\begin{array}{c}4.28 ; 0.039 \\
\text { SO clean }>\text { SO inf }>\text { Cleo inf }=\text { Cleo clean }\end{array}$ \\
\hline 3,4-Dimethylbenzamide & $\begin{array}{l}1939.14 ;<0.001 \\
\text { SO }>\text { Cleo }\end{array}$ & $\begin{aligned} 644.35 ; & <0.001 \\
\text { clean } & <\text { inf }\end{aligned}$ & $\begin{array}{c}333.17 ;<0.001 \\
\text { SO inf }>\text { SO clean }>\text { Cleo inf }>\text { Cleo clean }\end{array}$ \\
\hline $\begin{array}{l}\text { 1,15-Pentadecanedioic } \\
\text { acid }\end{array}$ & $\begin{array}{l}51.32 ;<0.001 \\
\mathrm{SO}>\mathrm{Cleo}=0\end{array}$ & $\begin{array}{c}14.80 ;<0.001 \\
\text { clean }<\inf \end{array}$ & $\begin{array}{c}14.80 ;<0.001 \\
\text { SO inf }>\text { SO clean }>\text { Cleo inf }=\text { Cleo clean }\end{array}$ \\
\hline 2-methyl-3-Heptanone & $\begin{array}{c}699.65 ;<0.001 \\
0=\mathrm{SO}<\text { Cleo }\end{array}$ & $\begin{array}{l}0.01 ; 0.952 \\
\text { clean }=\text { inf }\end{array}$ & $0.01 ; 0.952$ \\
\hline Benzaldehyde & $\begin{array}{l}90.90 ;<0.001 \\
0=\mathrm{SO}<\mathrm{Cleo}\end{array}$ & $\begin{array}{l}4.03 ; 0.050 \\
\text { clean }=\text { inf }\end{array}$ & $0.12 ; 0.732$ \\
\hline
\end{tabular}

${ }_{1}^{1}$ df were always 1. For volatiles for which the Plant*Occupation interaction is significant, means were separated according to Bonferroni $(P<0.05)$.

\subsubsection{The omnivorous predator $N$. californicus triggers defensive responses in sour orange and Cleopatra mandarin plants}

The JA, SA, and flavonoid signaling pathways homologous marker genes $L O X 2, P R 5$ and CHS, respectively, were analyzed in unoccupied and $N$. californicus-occupied plants and compared using Student $t$-test. While $L O X 2$ was upregulated in Cleopatra mandarin with occupation $(\times 2.1$; Figure $2.4 \mathrm{a})$, PR5 remained unchanged in both Citrus species (Figure $2.4 \mathrm{~b})$, and $C H S$ was downregulated in sour orange $(\times 0.5$; Figure $2.4 \mathrm{c})$. 


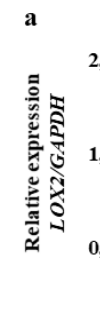

3

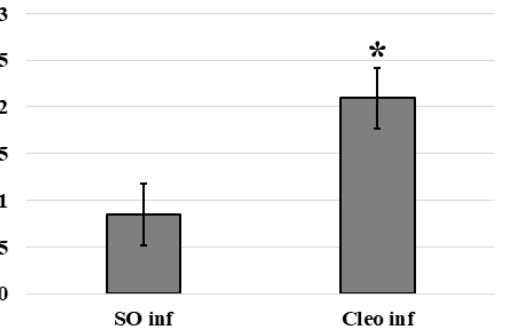

b $\quad 1,8$

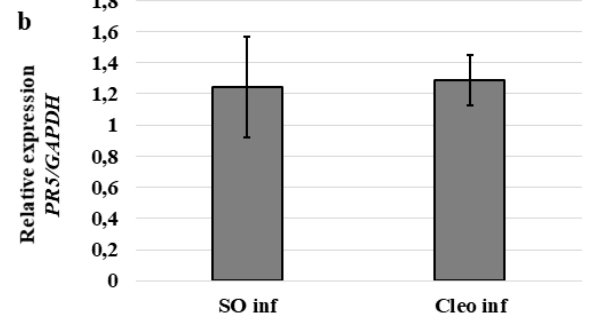

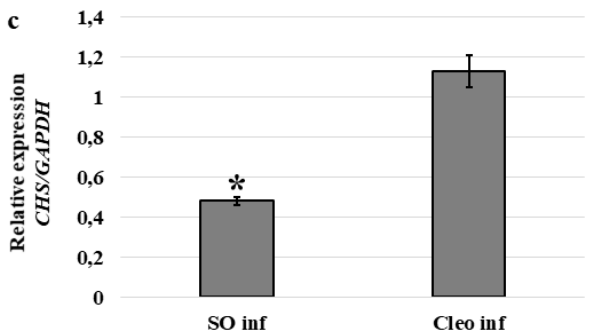

Figure 2.4 Relevance of (a) lypoxigenase 2, LOX2 (cit16759.1S1), (b) pathogenesis-related protein 5, PR5 (BAI63287.1), and (c) chalcone synthase, CHS (CF417078) in citrus defense triggered by $N$. californicus. Total RNA was extracted from the leaves of three plants per genotype (sour orange, SO, and Cleopatra mandarin, $\mathrm{Cleo}$ ) and occupation status (unoccupied and occupied with 25 mites, inf) 48 hours after occupation, converted to cDNA and subjected to quantitative RT-PCR analysis. Transcript levels were normalized to the expression of the housekeeping gene glyceraldehyde 3-phosphate dehydrogenase $(G A P D H)$ measured in the same sample. For each genotype, data are presented as a mean of transcript expression relative to unoccupied plants \pm SE $(n=3)$. Significant differences between unoccupied and occupied plants were estimated performing a Student $t$-test for each genotype. Asterisks indicate statistically significant differences $(P<0.05)$. 


\subsection{Discussion}

To the best of our knowledge, this is the first time that genotype-dependent plant defensive responses triggered by a phytoseiid not feeding on plant cell-sap (i.e., $N$. californicus) are described. Plant defense against herbivores has been traditionally attributed to either mechanical feeding damage or herbivory-derived elicitors which can be found in the oral secretions of the herbivore (Hilker and Meiners, 2010; Schuman and Baldwin, 2016), or to both of them, or to other herbivory-related secretions (i.e., aphid honeydew, Schwartzberg and Tumlinson, 2014). However, as N. californicus does not engage in plant-feeding (Adar et al., 2012). Thus, other triggers such as predator's footsteps, eggs and/or feces, should be the responsible for the observed responses. Because $P$. persimilis did not trigger this type of responses, our results prove that plant defense responses to non-feeding arthropod activities can be species-specific also for nonzoophytophagous species. As phytoseiids lack a specialized ovipositor, they cannot insert their eggs into the plant tissue. Therefore, elicitors of plant defense in N. californicus should most probably be related to touch and/or to touch-associated secretions. This could be the case of walking as the ambulacrum, which holds claws and empodium, couls cause injury when walking, but also of secretions released from the mite tarsal pads. Likewise, oviposition secretions produced in the female genitalia to facilitate egg pass through the genital opening and to fix and protect the egg onto the leaf surface (Di Palma and Alberti, 2001; Hilker and Meiners, 2010) could also trigger plant defense. Although the nature of the secretions that phytoseiids produce when walking and ovipositing remains largely ignored, there are conspicuous differences in the morphology and size of $N$. californicus and $P$. persimilis legs and body which could affect injury caused when walking. Croft et al. (1999) studied egg and body size in different phytoseiids including these two species. Also, Okassa et al. (2010) and Beaulieu and Beard (2018), re-described P. persimilis and $N$. californicus, respectively. According to these authors, $N$. californicus adult females are longer than P. persimilis. However, the later is wider, has longer legs and dorsal setae, and produces larger eggs than N. californicus. Most remarkably, the IV ambulacrum of P. persimilis presents more setae including a $85 \mu \mathrm{m}$ long barbed macroseta on the genu and a simple $125 \mu \mathrm{m}$ long macroseta on basitarsus than $N$. californicus, whose IV basitarsal macroseta is much shorter (49 $\mu \mathrm{m}$ long). Size differences, together with species-specific chetotaxy, may also explain why, contrary to $N$. californicus, $P$. persimilis did not trigger any defense response when walking on the plant. Indeed, 
chetotaxy of $P$. persimilis is key for its ability to penetrate and move inside $T$. urticae dense webs (Sabelis and Bakker, 1992).

Landing, walking and oviposition by an herbivorous arthropod on a host plant is a reliable indicator for an upcoming herbivory (Bandoly and Steppuhn, 2016). Therefore, for a plant using these activities as either a trigger for induced defense (Wu and Balwin, 2010; Hilker and Fatouros, 2015) or a priming signal to boost particular feeding-induced defense traits (Conrath, 2011) could be expected. The reactions observed in Cleopatra mandarin to $N$. californicus could, therefore, be related to this Citrus species mistakenly identifying the predator as a potential threat or as an indication of the presence of herbivores, which pose a risk to plants (Helms et al., 2019). However, for a mite not feeding on plant cell-sap, the triggering of such defensive responses would negatively affect the fitness of the hatching conspecific larvae, as the probability to survive and complete development would decrease. Although N. californicus and P. persimilis-occupied plants turned repellent for T. urticae (Figure 2.1) and this effect alone would affect the probability of the coming predator larvae to find suitable food (mostly $T$. urticae eggs), defense induction by N. californicus in Cleopatra mandarin (Figure 2.4) would further reduce prey populations, which could in turn accumulate higher amounts of plant secondary metabolites. However, these effects may not be as deleterious as one could initially think as the upregulation of $L O X 2$ in Cleopatra mandarin is one order of magnitude lower than in sour orange $(\times 2$ and $\times 10$, respectively) when attacked by $T$. urticae (Agut et al., 2014). Remarkably, E. stipulatus presence on both sour orange and Cleopatra mandarin resulted in a similar upregulation of $L O X 2(\times 2.5)$. Nevertheless, E. stipulatus-occupied plants resulted attractive to T. urticae (Cruz-Miralles et al., 2019), and this effect may compensate for a lower prey density. Whether the relative lower upregulation of LOX2 achieved by these phytoseiids in citrus has the same negative consequences for T. urticae as those observed in sour orange when attacked by this herbivore (Agut et al., 2014, 2016), deserves further studies. However, we should not neglect that the expected sequence for the colonization of a plant by a predator is to follow its prey rather than viceversa. Therefore, the effect of the upregulation of $L O X 2$ by N. californicus in Cleopatra mandarin, which did not upregulate the JA pathway upon T. urticae attack (Agut et al., 2014), may benefit the already occupied plant to better defend itself against the herbivore.

Only one compound out of the six volatiles differentially produced by sour orange and Cleopatra mandarin when exposed to $N$. californicus, namely cineole (Table 2.1, Figure 
2.3h), was also found when examining the response of the same Citrus spp. to $E$. stipulatus occupation (Cruz-Miralles et al., 2019). However, contrary to N. californicus, occupation by E. stipulatus decreased the emission of this compound. This volatile was not found in the blends elicited by $T$. urticae when feeding on the same plant species (Agut et al., 2014). Therefore, this terpenoid, which as other essential oils are recognized to show acaricidal activity against T. urticae (Badawy et al., 2010; Ribeiro et al., 2019), may play a crucial role in $T$. urticae plant choices and could explain attraction to $E$. stipulatus occupation (Cruz-Miralles et al., 2019) and repellence to N. californicusoccupied plants (Figure 2.1). Consequently, cineole deserves further research as it could be used to manipulate T. urticae populations. As two additional volatiles showed the same trend as cineole upon $N$. californicus occupation (1-phenyl-1-hexanone and 3,4dimethylbezamide; Figures $2.3 \mathrm{i}$ and $2.3 \mathrm{j}$ ), their involvement in the observed results cannot be excluded. It is widely recognized the importance of considering the whole blend of volatiles in stead of single compounds, when studying this type of behavioral responses (Gregg et al., 2018), as, indeed, they are known to change depending on context (Zhang and Sanderson, 1992; Pallini et al., 1999; Fernández Ferrari and Schausberger, 2013).

As pointed out earlier, T. urticae responded to the different odor sources used in our behavioral assays as expected (i.e., attraction to less defended plants and repellence for phytoseiid own odors). Similar observations had been made in previous studies involving T. urticae (Agut et al., 2015) and E. stipulatus (Cruz-Miralles et al., 2019). The upregulation of $L O X 2$ in Cleopatra mandarin observed upon $N$. californicus occupation (Figure 2.4a) may have reinforced the preference for clean plants of this genotype, which were relatively less defended than occupied ones (Figure 2.2a). However, the opposite did not occur for sour orange although CHS was downregulated (and therefore these plants were less defended) upon $N$. californicus occupation (Figure 2.4c). This can be taken as indicative of the over-ruling effects of the odors of these two phytoseiids for $T$. urticae choice but also of the key role of the JA over the flavonoids pathway for defense against this mite in Citrus sp. (Agut et al., 2014). These effects would also explain $T$. urticae choices when exposed to $P$. persimilis (Figure 2.1c) and this is not surprising as these volatiles are most likely reliable indicators of predator presence and therefore of an imminent predation risk (Zhang and Sanderson, 1992; Pallini et al., 1999; Fernández Ferrari and Schausberger, 2013). 
In the case of phytoseiid choices, our initial hypotheses had to be rejected. Same as it occurred with E. stipulatus (Cruz-Miralles et al., 2019), both predators preferred better protected clean sour orange plants to less protected clean Cleopatra mandarin plants (Fig 2.2), despite preference for Cleopatra mandarin was expected. This result may be due to phytoseiids perceiving stronger plant defense levels as a sign of prey presence. However, when $N$. californicus and P. persimilis responded to conspecific-occupied plants, choices did not follow this rationale. Moreover, the strong repellence observed in N. californicus for conspecific odors disappeared when the mite was occupying citrus (Figure 2.2a), whereas the neutral role played by $P$. persimilis own odors when offered alone affected choice when combined with citrus odors (Figure 2.2b). A similar situation was observed for E. stipulatus (Cruz-Miralles et al., 2019). Therefore, these results point at a highly relevant interaction between plant and phytoseiid own odors for phytoseiid choice. However, in the real world, predators would most probably follow prey infestation rather than predator presence. Indeed, in a similar study where the behavior of these three phytoseiid species when exposed to T. urticae occupied plants was characterized (Cabedo-López et al., 2019), all of them chose occupied plants, irrespective of their diet specializations and plant genotype.

\subsection{Conclusions}

Our results prove that phytoseiid non-feeding activities may affect their prey beyond predation through plant-mediated effects. Whether other phytoseiids not directly feeding on the plants where they live can activate similar defensive pathways and the usefulness of these effects to better protect our crops deserves further research under more realistic conditions to consider the whole community. This will allow a better understanding of the system and could be used to help refining current crop protection practices by exploiting the semiochemicals involved (i.e., cineole, which seems to play a crucial role for T. urticae in citrus) to increase the efficacy of biological control. 



\section{CAPÍTULO 3}

Predator scents and risk perception in a tritrophic system

Exploitation prey by phytoseiid mites

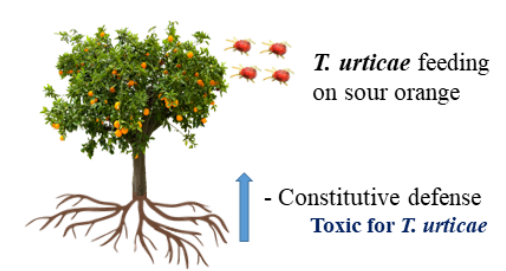

Sour orange citrus rootstock

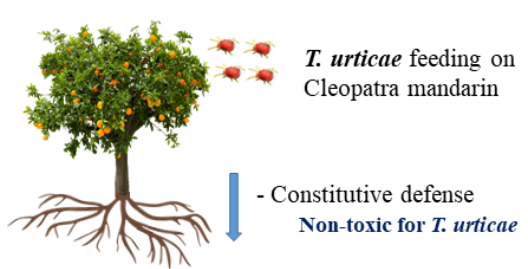

Cleopatra mandarin citrus rootstock

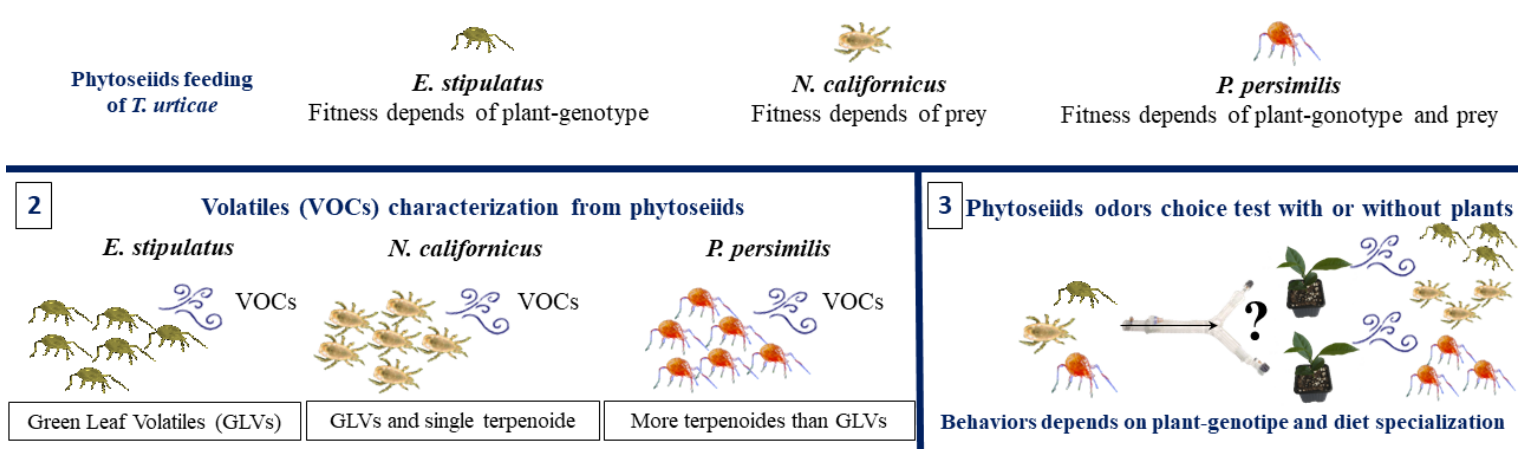

A version of this chapter has been submitted for publication:

Joaquín Cruz-Miralles, Marc Cabedo-López, Sandra Vacas, Vicente NavarroLlopis, Victoria Ibáñez-Gual, Meritxell Pérez-Hedo, Víctor Flors and

Josep A. Jaques 



\section{Abstract}

Recent studies have proven that plant the scent of the tetranychid mite Tetranychus urticae along with the herbivore induced plant volatiles associated to its feeding on citrus can affect the behavior of both conspecifics and some of its phytoseiid predators (i.e., Euseius stipulatus, Neoseiulus californicus and Phytoseiulus persimilis). Furthermore, the presence of E. stipulatus and $N$. californicus on these plants also triggers the production of volatiles affecting conspecifics as well as $T$. urticae. However, the effects of phytoseiid scents on intraguild (IG) interactions remain unexplored. We have characterized the composition of the volatile blends associated with these phytoseiids, their effect on the behavior of the other two IG predators, as well as their reproduction when preying on $T$. urticae feeding on two different citrus genotypes (i.e., Citrus aurantium and C. reshni).

Our results have shown that the volatile signature of the three phytoseiids is species specific and different from the shared prey, T. urticae. The blend associated with the plant cell-sap feeding E. stipulatus includes green leaf volatiles only, while monoterpenes dominate that of the entomophagous $P$. persimilis. One single monoterpene was present but not predominant in the scent of $N$. californicus, which presents an intermediate diet specialization. These unique scents can be perceived by plants, herbivores and potential IG competitors and trigger species specific responses linked to risk perception. On the one hand, changes in plant defense observed upon exposure to $N$. californicus could be related to citrus plants perceiving phytoseiid odors as a cue of an imminent herbivory risk. On the other, behavioral changes in mites when exposed to predator-occupied compared to predator-void plants could be also related to perception of these odors as cues for either an imminent predation risk for T. urticae or competition from a superior IG predator, most likely P. persimilis, for the other two phytoseiid species. As E. stipulatus is the only phytoseiid from the three considered in this study for which non-negative effects from attraction to uninfested plants can be anticipated, it could provide support to the occurrence of mutualism between first and third trophic levels.

KEY-WORDS: Chemical ecology; Citrus; HIPV; Phytoseiidae; Plant defense; Predatory mite; Tetranychus urticae 



\subsection{Introduction}

Phytoseiid mites (Acari; Mesostigmata; Phytoseiidae) have a diversity of lifestyles related to food utilization (McMurtry and Croft, 1997; McMurtry et al., 2013), ranging from specialized predators of herbivorous spider mites belonging to the genus Tetranychus Dufour (Acari; Prostigmata; Tetranychidae) (i.e., Phytoseiulus persimilis (AthiasHenriot)), to pollen feeders that also feed on microarthropods and, importantly, on plant cell-sap (i.e., the genus Euseius De Leon). Intermediate diet specializations are common in this family (McMurtry and Croft, 1997; McMurtry et al., 2013). In citrus, the herbivorous Tetranychus urticae Koch and the phytoseiid predators P. persimilis, Euseius stipulatus (Athias-Henriot), and Neoseiulus californicus (McGregor), which exhibits an intermediate lifestyle feeding on both plant and animal-derived food but which does not engage in plant cell-sap feeding (Adar et al., 2012), coexist (Aguilar-Fenollosa et al., 2011a,b). The relative abundance of these three phytoseiids in Spanish citrus orchards is not the same. E. stipulatus is the most abundant species in both the canopy and the associated cover crops, irrespective of the species/cultivar and management practices used and may represent more than $70 \%$ of total phytoseiids (Abad-Moyano et al., 2009b; Aguilar-Fenollosa et al., 2011b; Vela et al., 2017). The other two species represent from $5-15 \%$ and usually disappear from the system when citrus are grown on bare soil (Aguilar-Fenollosa et al., 2011b). In spite of these contrasting figures, Pérez-Sayas et al. (2015) demonstrated in a field study where predation by these species was analyzed by gut-content analysis, that only $28.4 \%$ of E. stipulatus specimens proved positive for $T$. urticae feeding, whereas this figure boosted to $75.7 \%$ for $P$. persimilis, which demonstrates the important contribution of both predators to the regulation of this herbivore.

Recent studies (Cruz-Miralles et al., 2019, chapter 2) have shown that, similar to other zoophytophagous predators (Arnó et al., 2009; De Puysseleyr et al., 2011; Perdikis, et al., 2011; Messelink et al., 2015; Pappas et al., 2015; Pérez-Hedo et al., 2015; Bouagga et al., 2018; Zhang et al., 2018), E. stipulatus can induce plant defense responses in citrus whereas the strict entomophagous $P$. persimilis does not. Interestingly, $N$. californicus can also induce this type of plant responses and this proves that non-feeding activities (i.e., oviposition, ambulatory movement) can trigger plant defense in Phytoseiidae. CruzMiralles et al. (2019; chapter 2) focused their studies on two citrus species: sour orange, Citrus aurantium L. and Cleopatra mandarin, Citrus reshni Hort. ex Tan., as they display 
extreme resistance and susceptibility to the herbivorous prey $T$. urticae, respectively (Bruessow et al., 2010). These differences were attributed to a higher constitutive and earlier inducible direct defense upon T. urticae attack in sour orange compared to Cleopatra mandarin (Agut et al., 2014) (Table 3.1). These genotype dependent responses triggered by an herbivore were closer to those induced by E. stipulatus (Cruz-Miralles et al., 2019) than to N. californicus (chapter 2) and this may be related to plant cell-sap feeding in E. stipulatus. The volatile blends associated with these responses were characterized (Agut et al., 2015; Cruz-Miralles et al., 2019, chapter 2). Moreover, the behavior of (1) T. urticae when exposed to these odors and (2) that of the three phytoseiid when exposed to conspecific odors (Cruz-Miralles et al., 2019; chapter 2) as well as to those of T. urticae (Agut et al., 2015; Cabedo-López et al., 2019), was described. Although avoidance of better protected plants, either because of higher direct (i.e., plant basal and inducible) or indirect (i.e., predator presence) defense, was expected both for the herbivore (as these plants have more secondary toxic metabolites and to avoid predation) and the predators (as these plants are presumed to offer lower prey densities and to avoid cannibalism), this was not always the case. In general, T. urticae followed this rationale (Cabedo-López et al., 2019; Cruz-Miralles et al., 2019; chapter 2). However, predators' responses demonstrated that higher direct defense may be perceived as a sign of infestation and therefore, even prey-void plants could result attractive for predators. This behavior, though, depended on the phytoseiid lifestyle, with omnivores responding both to plant and prey-associated odors and specialists mostly to prey. Because confusing natural enemies in their efforts to locate the herbivores may have a cost for predators (Turlings and Ton, 2006), these results deserve further research.

Table 3.1 Effect of mite presence on the relative expression of plant defense pathways in occupied compared to unoccupied citrus plants $(\uparrow=$ upregulation; $\downarrow=$ downregulation; NE $=$ no effect $)$. Two citrus species were considered: sour orange (SO) and Cleopatra mandarin (CM). Occupied plants $\left(\mathrm{SO}_{\text {mite, }}, \mathrm{CM}_{\text {mite }}\right)$ had been exposed to 25 mites for 48 hours prior to the onset of the assay. Unoccupied plants $\left(\mathrm{SO}_{\varnothing}, \mathrm{CM}_{\varnothing}\right)$ had been maintained separated from occupied ones until the onset of the assay.

\begin{tabular}{lllll}
\hline Citrus species & $\boldsymbol{T}$. urticae & $\boldsymbol{E}$. stipulatus & $\boldsymbol{N}$. californicus & P. persimilis \\
\hline $\mathbf{S O}_{\text {mite }} \mathbf{v s} \mathbf{S O} \mathbf{O}_{\varnothing}$ & $\mathrm{JA} \uparrow ; \mathrm{SA} \uparrow ;$ Flav $\uparrow(1)$ & $\mathrm{JA} \uparrow ; \mathrm{SA} \uparrow ;$ Flav $\uparrow(2)$ & $\mathrm{Flav} \downarrow$ & $\mathrm{NE}$ \\
& & & $(3)$ & $(3)$ \\
$\mathbf{C M}_{\text {mite }} \mathbf{v s} \mathbf{C} \mathbf{C M}_{\varnothing}$ & $\mathrm{SA} \uparrow$ & $\mathrm{JA} \uparrow ; \mathrm{Flav} \downarrow$ & $\mathrm{JA} \uparrow$ & $\mathrm{NE}$ \\
& $(1)$ & $(2)$ & $(3)$ & $(3)$
\end{tabular}

References in brackets: 1: Agut et al., 2014; 2: Cruz-Miralles et al. 2019; 3: Chapter 2 
To date, the behavioral responses of the three aforementioned phytoseiid species when exposed to the odor blends associated with the other two heterospecifics (either mite own odors or those of mite occupied plants), have not been studied (Figure 3.1). Gaining knowledge on them is important to better understand this system. While it is widely acknowledged that intraguild (IG) predation occurs between phytoseiids (Schausberger and Croft, 2000), Guzmán et al. (2016) demonstrated that it might not be so common. Instead, exploitative resource competition and predator-prey interactions may be the rule, especially in the presence of a shared resource. In a semi-field assay, Abad-Moyano et al. (2010a) suggested that the IG interactions between E. stipulatus and P. persimilis resulted lethal for the latter while those between E. stipulatus and N. californicus did not. More recently, Urbaneja-Bernat et al. (2019) also characterized IG interactions between these species in semi-field assays. However, in this case, $P$. persimilis appeared as the most successful competitor and the occurrence of lethal IG interactions among these species could not be proven. Same as before, as a positive correlation between heterospecific phytoseiid avoidance and predator performance is expected, the characterization of the behavioral responses of the three phytoseiids to the odors of the other two heterospecifics may challenge this hypothesis.

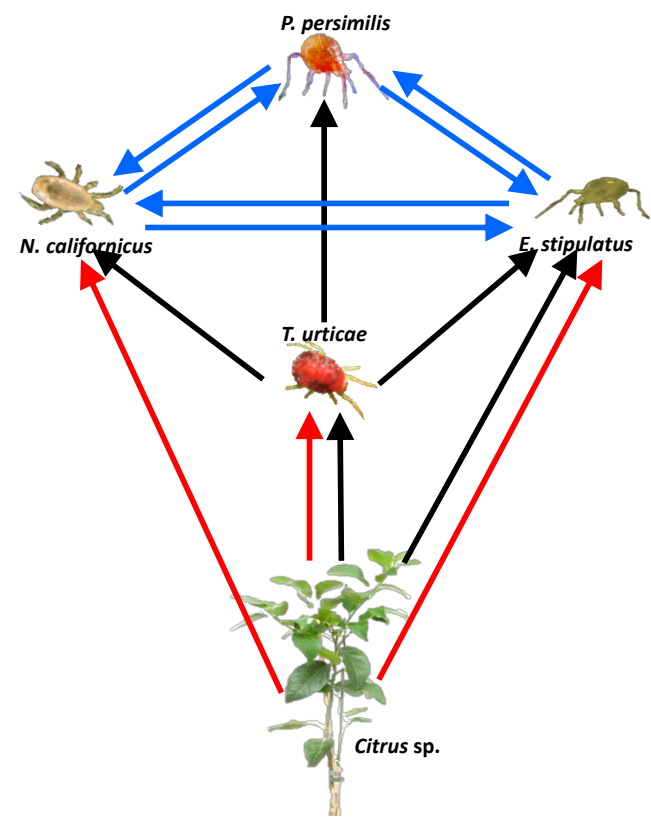

Figure 3.1 Interactions between citrus plants, the herbivorous two-spotted spider mite and three of its potential predators with different diet specializations. Solid black arrowheads reflect consumption and point to higher trophic levels; solid red arrowheads indicate induced plant resistance (see table 1); and solid blue arrowheads reflect intraguild interactions. 
In this study, we have studied the behavior of the three phytoseiids above when exposed to heterospecifics by means of a series of Y-tube olfactory choice assays (Bruinet al., 1992) using the two citrus genotypes already characterized in terms of their defense response to these mites (defensive pathways and volatile blend profiles): sour orange and Cleopatra mandarin (Agut et al., 2014, 2015; Agut et al., 2016; Cabedo-López et al., 2019; Cruz-Miralles et al., 2019; chapter 2). We have also characterized the volatile blends associated with these phytoseiids as well as their reproduction when preying on T. urticae feeding on either sour orange or Cleopatra mandarin. Our final goal has been to understand how plant defense may modulate the strength of the relationships between these species and understand how this may affect the regulation of T. urticae in citrus.

\subsection{Materials and methods}

\subsubsection{Plant material}

Three-month-old plants of sour orange and Cleopatra mandarin plants, the two citrus species exhibiting extreme responses to T. urticae (Bruessow et al., 2010) were used in our assays. They were grown on vermiculite and peat (1:3; vol:vol) in 320-ml pots in a climatic chamber at $60 \pm 10 \%$ relative humidity $(\mathrm{RH})$ and under a 16:8 h light/dark photoperiod combined with a day/night thermal regime of $25 \pm 2 \circ \mathrm{C}$ and $20 \pm 2 \circ \mathrm{C}$ following standard procedures (Cruz-Miralles et al., 2019). Pesticide-free lemon fruits (Citrus limon (L.) Burm f.), and bean plants (Phaseolus vulgaris L. cv. Buenos Aires Roja) cultivated at UJI Campus were used to maintain T. urticae stock colonies and phytoseiid mites, respectively. Additionally, pesticide-free clementine mandarin leaves (C. clementina Hort. ex Tan. cv. Clementina de Nules grafted on citrange Carrizo rootstock) obtained from the same campus were used to rear E. stipulatus for the characterization of its associated volatiles (see below).

\subsubsection{Spider mite stock colony}

The colony of $T$. urticae used to feed $P$. persimilis (see below) was initiated with specimens originally collected in 2001 in clementine orchards near UJI campus. Spider mites were maintained on lemons kept in a climatic chamber using standard procedures (Cruz-Miralles et al., 2019). 


\subsubsection{Phytoseiidae mites stock colonies}

The colonies of E. stipulatus and $P$. persimilis were initiated with specimens originally collected in 2012 in clementine orchards near UJI campus. These phytoseiids were maintained in a climatic chamber at the same environmental conditions as before. The rearing took place on detached leaf units consisting of a single bean leaflet placed upside down on moistened cotton, placed on top of a water-saturated foam cube $(3-4 \mathrm{~cm}$ thick) in an open plastic box $\left(35 \times 20 \times 7 \mathrm{~cm}^{3}\right)$ half-filled with water. Moist cotton was folded over the edges of the leaves to prevent mites from escaping. E. stipulatus was fed pollen of Typha L. spp. (Typhaceae), which was added every 3 days, whereas $P$. persimilis was fed a mix of different stages of $T$. urticae provided twice a week.

Neoseiulus californicus was obtained from Koppert Biological Systems (Spical®). Adult females were individually moved with a soft-bristle paintbrush from the rearing substrate to an arena consisting of a thin black plastic board ( $9.5 \mathrm{~cm}$ diameter) placed on top of a water-saturated foam cube $(3-4 \mathrm{~cm}$ thick $)$ in an open plastic box $(20 \times 15 \times 4 \mathrm{~cm} 3)$ halffilled with water to prevent mites escaping from the arena. These females were subsequently used in our assays without any further rearing.

Phytoseiid adult females were used in the Y-tube olfactory choice tests (see below) either to determine their preferences or as an odor source. In the former case, prior to their use, females were subjected to a $24-\mathrm{h}$ starvation period in $50 \mathrm{ml}$ plastic vials in groups of 7 following Cruz-Miralles et al. (2019). When used as an odor source, 25 adult females were either deposited on different leaves of the same young plant using a soft-bristle paintbrush, or moved to a meshed bag $(10 \times 5 \mathrm{~cm})$ closed with a magnet. To prevent ambulatory mite movement between plants, pots were isolated from each other by singly setting them in $14 \times 14 \times 7 \mathrm{~cm}$, placed in another larger tray filled with water. Occupied plants remained in a climatic chamber for up to 48 hours before use. Plants were kept separated by both genotype and occupation status to avoid any exposure to plant volatiles from the other treatments, which could induce undesired plant defensive responses (Agut et al., 2015).

For volatile extraction, P. persimilis were obtained from Koppert Biological Systems (Spidex ${ }^{\circledR}$ ), as we were not able to produce the large amounts required. These specimens were processed as $N$. californicus. In the case of E. stipulatus, separate volatile extractions from specimens obtained from bean and citrus detached leaf colonies were performed. 


\subsubsection{Y-tube olfactory choice assays}

Olfactory choice assays were conducted using a Y-tube olfactometer (Bruin et al., 1992) following the same procedure as in our previous work (Agut et al., 2014; Cruz-Miralles et al., 2019; chapter 2). These assays involve the use of a Y-shaped glass tube containing a Y-shaped 1-mm diameter metal wire. The two short arms are directly connected to the outlets of two identical 5-1 glass vessels containing different odor sources. Each vessel is connected to an air pump producing a unidirectional airflow of purified air of $1.5 \mathrm{l} / \mathrm{h}$ from the arms to the base of the tube. Environmental conditions inside the Y-tube were $23 \pm$ $2^{\circ} \mathrm{C}$ and $60 \pm 10 \%$ RH (Cruz-Miralles et al., 2019). Starved adult females were individually deposited at the beginning of the long arm using a soft-bristle paintbrush and allowed to make a choice within $10 \mathrm{~min}$. As soon as a mite reached the end of one of the two short arms of the wire, the mite was removed and discarded. Mites failing to reach either end of the short arms within the allocated time were scored a "no choice". Different 2-choice experiments involving phytoseiid-occupied and unoccupied young plants of both genotypes, as well as phytoseiids alone were performed. 40 responding mites per odor combination were considered. Each combination was evaluated four times at different dates (i.e., four replicates). Each replicate included 10 responding mites, which meant that up to 13 mites per combination per date were tested as the non-choice rate ranged from 0 to 3 . The glass vessels were switched to reduce the effects of spatial influence on choice. In the case of assays with plants, these were replaced after every 10 females had been tested, and the whole system was rinsed with ethanol (70\%), followed by air drying. To exclude any bias from the set-up, before the beginning of the assays, 10 mites were exposed to clean air in both arms. A random choice was expected.

\subsubsection{Prey profitability}

The performance of the three phytoseiid species when preying on T. urticae feeding on either sour orange or Cleopatra mandarin plants was evaluated. Three replicates of eight plants per citrus genotype and phytoseiid species were included. The eight plants were occupied with 25 adult females of T. urticae obtained from the lemon fruit stock colony. These plants were maintained in climatic chambers separated by plant genotype at the same conditions as before during eight days. At that date three plants per genotype were cut in pieces and individually placed in a beaker with $500 \mathrm{ml}$ of $70 \%$ (vol) ethanol. This 
mixture was stirred for 10 minutes with a glass stirring rod. Then, the suspension was poured onto a cellulose nitrate filter with a pore size of $0.45 \mu \mathrm{m}$ (Sartorius Stedim Biotech; Barcelona, Spain) fitted to a filtration unit PSF 500/500ml (Thermo Fisher Scientific Inc.; Sant Cugat del Vallès, Spain) which were counted under a binocular microscope. The remaining five plants per genotype were occupied with three young adult female phytoseiids and left undisturbed under the same environmental conditions for five additional days. Then, plants were processed as before and finally all stages of both $T$. urticae and phytoseiids were counted. With these data we could relate phytoseiid population at day 5 after phytoseiid introduction with $T$. urticae decreasing populations between days 0 and 5 as a measure of prey profitability.

\subsubsection{Characterization of phytoseiid associated volatiles}

Groups of 400-700 phytoseiid specimens (mixed stages and sexes) were placed in 2-ml closed screw-cap headspace vials by carefully brushing the rearing substrate. Volatiles were collected in static conditions by solid-phase microextraction (SPME) using the same procedure already used for collecting T. urticae associated odors (Cabedo-López et al., 2019). Supelco SPME fibers (PDMS/ DVB), film thickness $=100 \mu \mathrm{m}$ (Supelco Inc., Bellefonte, PA, USA) conditioned before volatile sampling in a $\mathrm{GC}$ injector at $250^{\circ} \mathrm{C}$ for 10 min under a $20 \mathrm{ml} \mathrm{min}^{-1}$ helium flow rate, were exposed to each sample for $24 \mathrm{~h}$ at 23 $\pm 2{ }^{\circ} \mathrm{C}$, under a 16:8 h L:D photoperiod (Alfaro et al., 2011). Nine replicates per species were carried out with different groups of individuals. SPME fibers were thermally desorbed into the $\mathrm{GC}$ injection port, set at $250^{\circ} \mathrm{C}$ for $1 \mathrm{~min}$, and operated in the splitless mode. The extracted volatiles were analyzed by GC-MS using a Clarus 600 GC-MS (PerkinElmer Inc., Wellesley, MA, USA). The column used was a $30 \mathrm{~m} \times 0.25 \mathrm{~mm}$ i.d., $0.25 \mu \mathrm{m}$ film thickness, ZB-5MS fused silica capillary column (Phenomenex Inc., Torrance, CA, USA). The oven was held at $40^{\circ} \mathrm{C}$ for $2 \mathrm{~min}$ and then programmed at $5^{\circ} \mathrm{C}$ $\min ^{-1}$ to $180^{\circ} \mathrm{C}$; when reached, temperature was raised to $280^{\circ} \mathrm{C}$ at $10^{\circ} \mathrm{C} \mathrm{min}^{-1}$ and maintained at $280^{\circ} \mathrm{C}$ for $1 \mathrm{~min}$ (total analysis run of $41 \mathrm{~min}$ ). Helium was used as the carrier gas with a flow rate of $1.2 \mathrm{ml} \mathrm{min}^{-1}$. Detection was performed in the EI mode (ionization energy, $70 \mathrm{eV}$; source temperature, $180^{\circ} \mathrm{C}$ ), and spectra acquisition was done in the scanning mode (mass range $\mathrm{m} / \mathrm{z} 35-400$ ). Chromatograms and spectra were recorded with GC-MS Turbomass software version 5.4 (PerkinElmer Inc.). Volatiles were identified by either comparing their retention times and mass spectra with those of 
pure standards (Sigma-Aldrich) or by matching to the National Institute of Standards and Technology library (NIST\EPA\NIH Mass Spectral Library, version 2.0, build 4/2005) using match values of at least $>80 \%$ as a threshold for identification, as described by Wallis et al. (2008). The different peak areas in the chromatograms corresponding to these compounds were calculated and used to estimate their relative abundance in the blend.

\subsection{Results}

\subsubsection{The presence of IG competitors can modify the response of phytoseiids to citrus odors}

To check whether our hypothesis that the presence of predators on the plant could alter the behavior of heterospecific phytoseiids, we performed a series of 2-choice tests. Results of each preference test were initially subjected to logistic regression to check for the effect of replicate $(n=4)$ on mite preference. Because this effect was not significant $(P>0.05)$ in all cases, the results of the four replicates per choice test were pooled and subjected to chi-square analysis to test whether they departed from a 1:1 distribution. IBM SPSS Statistics 23 was used. In agreement with previous results (Cruz-Miralles et al., 2019; Cabedo-López et al., 2019) the three phytoseiids preferred sour orange to Cleopatra mandarin when both genotypes were unoccupied (Figures 3.2a, 3.3a, 3.4a). However, this preference changed when phytoseiids were present on the plant. In the case of $E$. stipulatus (Figure 3.2), a preference for Cleopatra occupied plants was observed irrespective of the occupying heterospecific phytoseiid (N. californicus or P. persimilis, Figs. 3.2b, 3.2c, respectively). Sour orange became even repellent when occupied by $P$. persimilis (Figure 3.2c). Interestingly, E. stipulatus was attracted to odors of both conspecifics and $N$. californicus but repelled by P. persimilis (Fig 3.2d). A similar situation was observed for $N$. californicus when responding to occupied plants (Figure 3.3). However, in this case phytoseiid-occupied sour orange became repellent when occupied by either E. stipulatus (Figure 3.3b) or P. persimilis (Figure 3.3c). N. californicus was attracted to conspecific odors but repelled by those produced by heterospecifics (Figure 3.3d). Finally, P. persimilis showed no preference for any phytoseiid-occupied plant, irrespective of the occupying species (Figures 3.4b, 3.4c) and it was repelled by E. stipulatus odors only. These results show that phytoseiid plant choices can be altered by the presence of potential competitors and thus result in nonlethal IG interactions that may affect the shared prey beyond predation. 


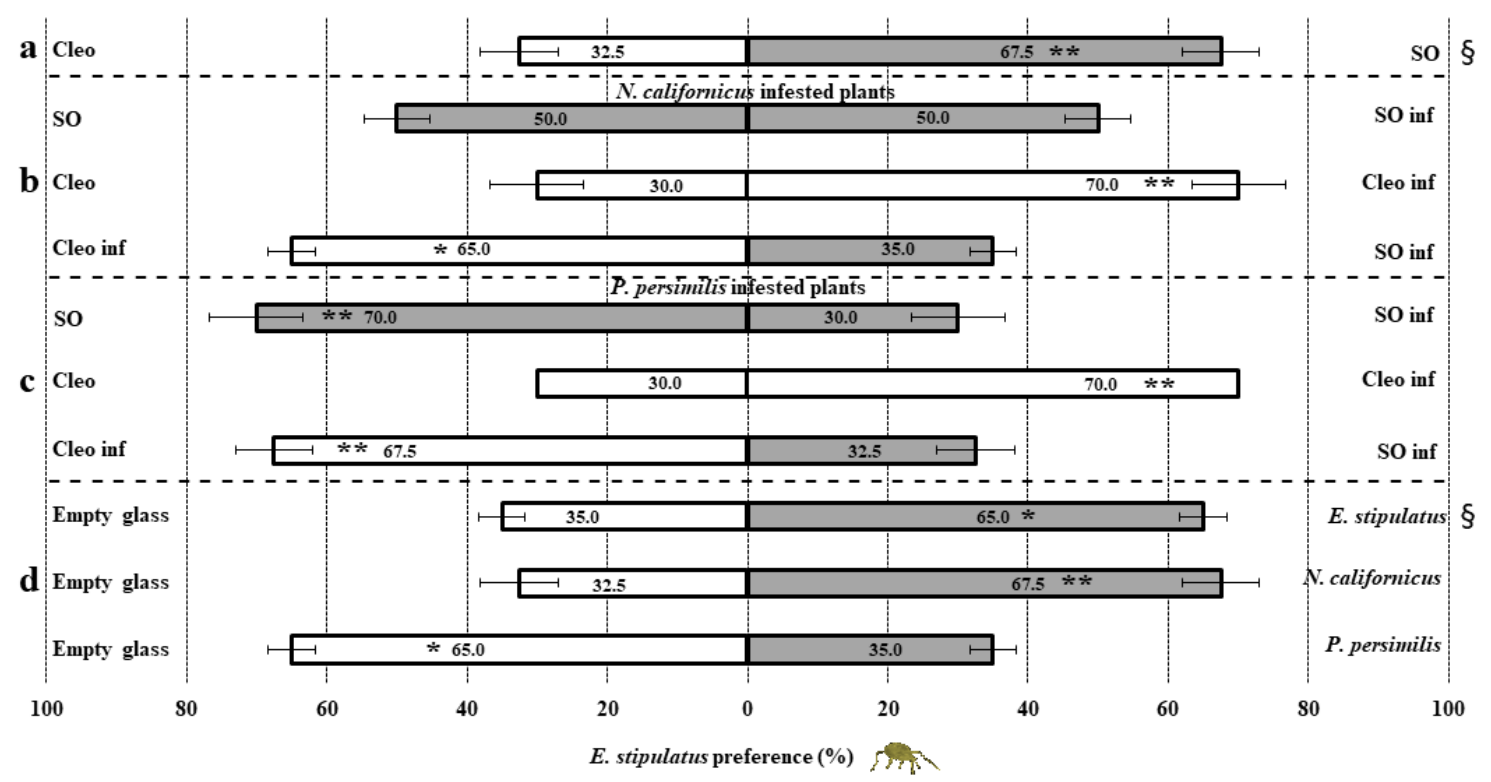

Figure 3.2 Olfactory responses of E. stipulatus adult females to (a) Cleopatra mandarin control plants (Cleo) vs sour orange control plants (SO), (b) N. californicus- and (c) P. persimilisoccupied plants, and (d) the former two phytoseiid species with no plant. Different combinations, in which E. stipulatus had to choose between two odor sources, were tested. A minimum of 40 adult females per choice combination was tested. These females were subjected to a starvation period of $24 \mathrm{~h}$ prior to the onset of the assay. Asterisks indicate significant differences from a 1:1 distribution (one asterisk: chi-square test $P<0.10$, two asterisks: chi-square test $P<0.05$ ).

${ }^{\S}$ This result was taken from Cruz-Miralles et al. (2019) developed in chapter 1. 


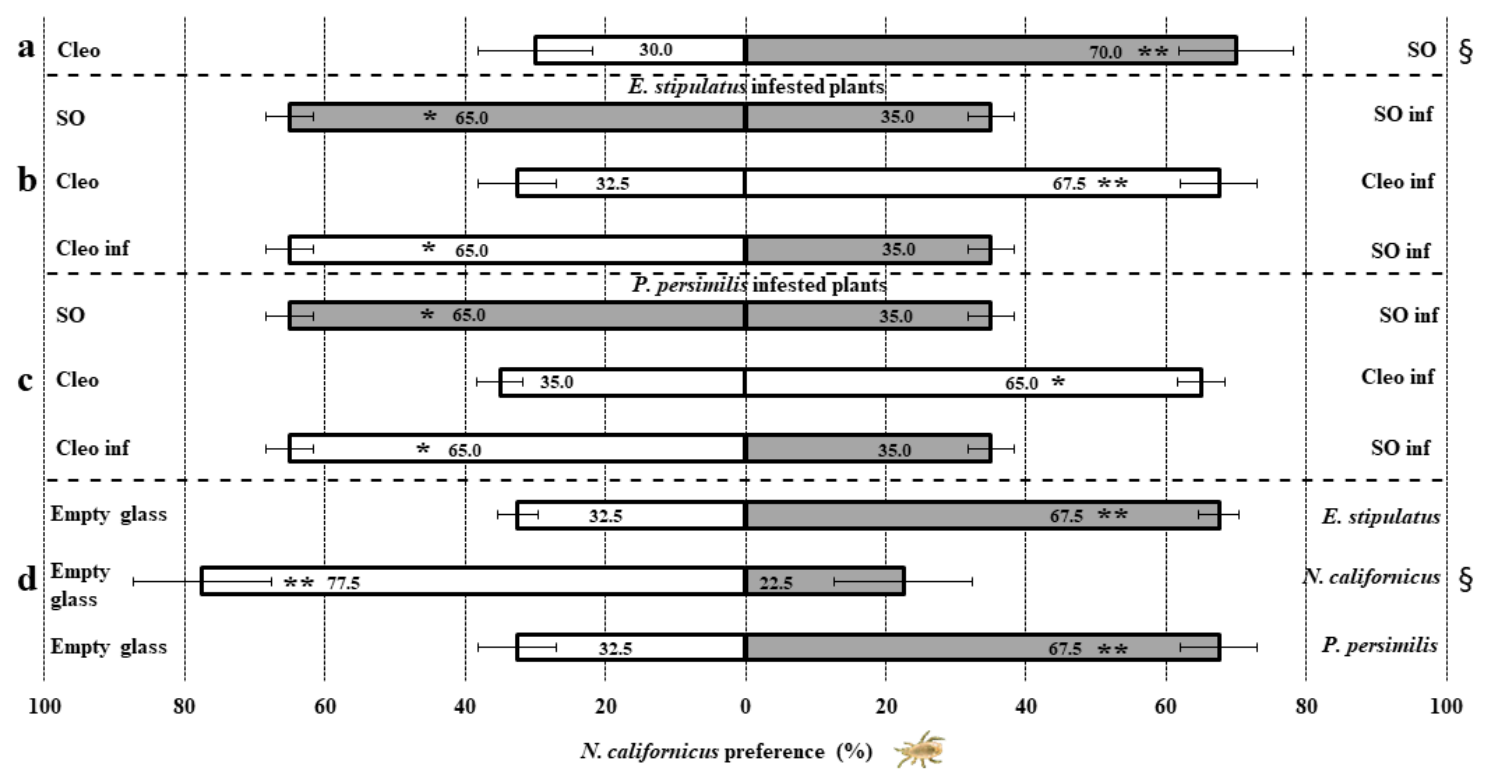

Figure 3.3 Olfactory responses of $N$. californicus adult females to (a) Cleopatra mandarin control plants (Cleo) vs sour orange control plants (SO), (b) E. stipulatus- and (c) P. persimilis-occupied plants, and (d) the former two phytoseiid species with no plant. Different combinations, in which $N$. californicus had to choose between two odor sources, were tested. A minimum of 40 adult females per choice combination was tested. These females were subjected to a starvation period of $24 \mathrm{~h}$ prior to the onset of the assay. Asterisks indicate significant differences from a 1:1 distribution (one asterisk: chi-square test $P<0.10$, two asterisks: chi-square test $P<0.05$ ).

${ }^{\S}$ This result was taken from chapter 2. 


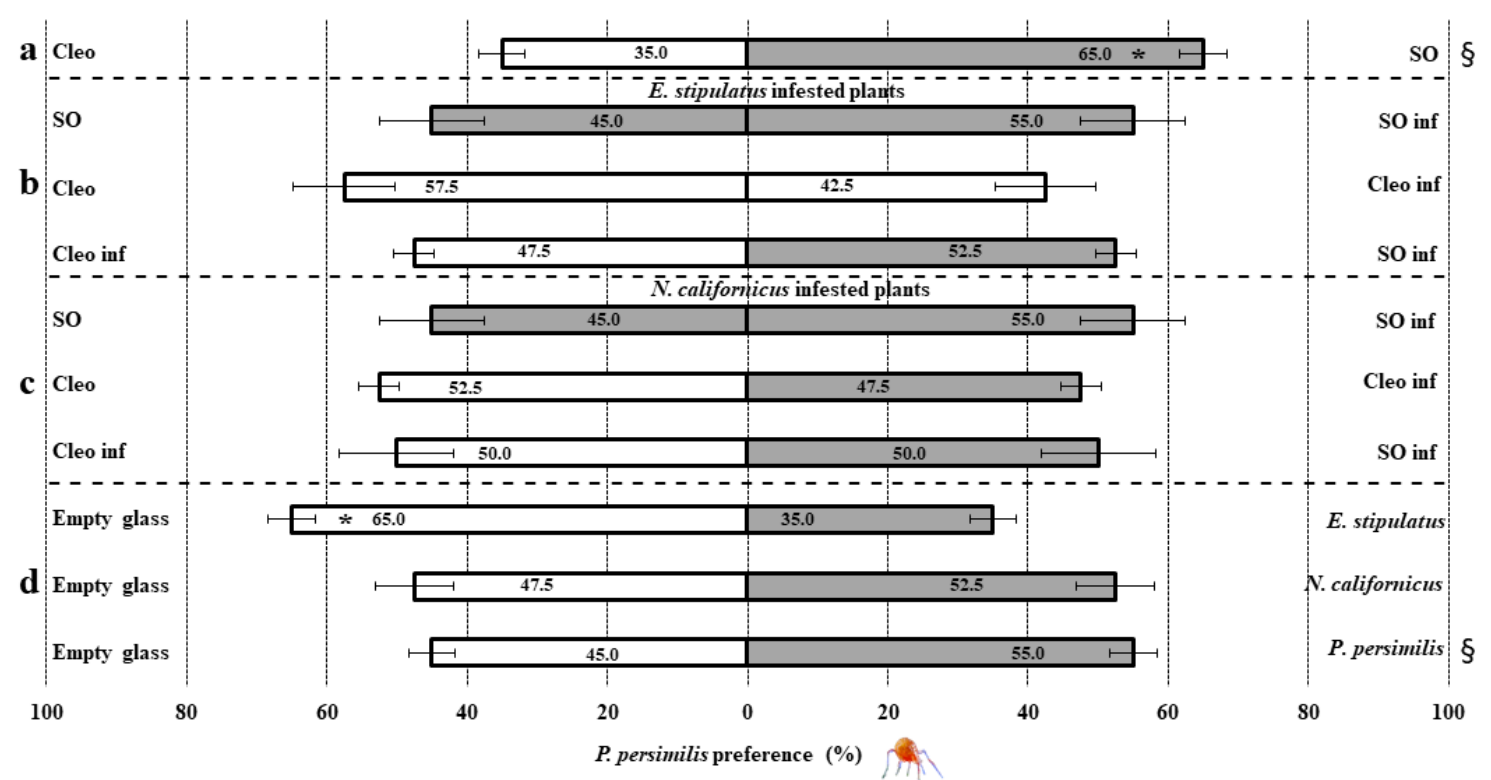

Figure 3.4 Olfactory responses of $P$. persimilis adult females to (a) Cleopatra mandarin control plants (Cleo) vs sour orange control plants (SO), (b) E. stipulatus- and (c) N. californicusoccupied plants, and (d) the former two phytoseiid species with no plant. Different combinations, in which P. persimilis had to choose between two odor sources, were tested. A minimum of 40 adult females per choice combination was tested. These females were subjected to a starvation period of $24 \mathrm{~h}$ prior to the onset of the assay. Asterisks indicate significant differences from a 1:1 distribution (one asterisk: chi-square test $P<0.10$, two asterisks: chi-square test $P<0.05$ ).

${ }^{\S}$ This result was taken from chapter 2. 


\subsubsection{The host plant where prey feeds affects its profitability for phytoseiids}

Mean ( $\pm \mathrm{SE}$ ) densities of T. urticae on Cleopatra mandarin and sour orange before the release of phytoseiids were $205.23 \pm 15.02(\mathrm{n}=26)$ and $149.12 \pm 11.93(\mathrm{n}=25)$ individuals (all stages and sexes together) per plant, respectively. We assumed T. urticae decreasing densities between that date and 5 days later to be representative of predation, which was defined as the difference between mean initial and final prey densities per plant. As in some cases, and contrary to our expectations, T. urticae populations increased after phytoseiid introduction (Table 3.2), these negative values were computed as zero (nil predation).

Table 3.2 Mean number of phytoseiid specimens per plant found at the end of the assay (day 13; 5 days after phytoseiid introduction), difference between the mean numbers of $T$. urticae specimens found at days 8 and 13 after initial occupation $(Z)$ and number of plants where $Z$ was negative (i.e., increasing $T$. urticae populations, no predation), which were excluded from $Z$ calculations. Means of 3 replicates of 8 plants per phytoseiid species and plant genotype.

\begin{tabular}{|c|c|c|c|}
\hline $\begin{array}{l}\text { \# Phytoseiid specimens per } \\
\text { plant }\end{array}$ & $\begin{array}{c}\text { Plant } \\
\text { genotype }\end{array}$ & Predation & $\begin{array}{c}\text { Replicates where } \\
\text { predation } \leq 0\end{array}$ \\
\hline \multicolumn{4}{|l|}{ E. stipulatus } \\
\hline $2.27 \pm 0.41$ & SO & $11.84 \pm 5.04$ & 8 \\
\hline $4.27 \pm 0.64$ & $\mathbf{C M}$ & $13.24 \pm 3.37$ & 6 \\
\hline \multicolumn{4}{|c|}{$\begin{array}{l}\mathrm{AIC}=126.435 ; \text { GLM results }\left(\text { Wald- } \chi^{2} ; \mathrm{P}^{\dagger}\right) \text { : Plant genotype }(\mathrm{A}): 9.555,0.002 ; \text { Predation }(\mathrm{B}): 2.434,0.119 \\
\text { Interaction } \mathrm{A}^{*} \mathrm{~B}: \mathrm{ns} \text { and excluded from model }\end{array}$} \\
\hline \multicolumn{4}{|l|}{ N. californicus } \\
\hline $6.73 \pm 0.72$ & SO & $45.49 \pm 10.66$ & 3 \\
\hline $6.40 \pm 0.95$ & $\mathbf{C M}$ & $55.18 \pm 12.25$ & 2 \\
\hline \multicolumn{4}{|c|}{$\begin{array}{l}\text { AIC }=143,340 ; \text { GLM results }\left(\text { Wald- } \chi^{2} ; \mathrm{P}^{\dagger} \text { ): Plant genotype }(\mathrm{A}): 0.004,0.951 ; \text { Predation }(\mathrm{B}): 15.317,<0.00\right. \\
\text { Interaction: } \mathrm{A}^{*} \mathrm{~B}: \mathrm{ns} \text { and excluded from model }\end{array}$} \\
\hline \multicolumn{4}{|l|}{ P. persimilis } \\
\hline $13.40 \pm 1.77$ & SO & $120.48 \pm 18.28$ & 0 \\
\hline $15.40 \pm 1.71$ & $\mathbf{C M}$ & $196.11 \pm 13.36$ & 2 \\
\hline
\end{tabular}

df were always 1

To check whether phytoseiid final densities were affected by the citrus genotype where their prey had been feeding, for each species separately, phytoseiid populations at day 5 
were compared using a Generalized Linear Model (GLM) with a Poisson distribution of the error and identity link function. Plant genotype and predation were used as fixed effects $(P<0.05)$. Phytoseiid densities in sour orange and Cleopatra mandarin were significantly different for all three species (Table 3.2). Lowest predation and phytoseiid density values were registered for E. stipulatus, which barely reproduced during the period considered. Phytoseiid density was significantly affected by citrus genotype but not by predation. In agreement with our hypothesis, Cleopatra mandarin provided better quality prey than sour orange $(0.32$ versus 0.19 phytoseiids per prey item consumed, ppic). In the case of $N$. californicus, only predation affected phytoseiid density, which was higher on sour orange than on Cleopatra mandarin. As predation was lower on sour orange, this result clearly indicates that $T$. urticae fed on sour orange is more profitable for $N$. californicus $(0.12$ versus 0.15 ppic in Cleopatra mandarin and sour orange, respectively). Highest predation and phytoseiid densities were observed for $P$. persimilis and in this case, the latter was affected by plant genotype, predation, and their interaction. Although highest phytoseiid densities were observed in Cleopatra mandarin, this was at the expense of consuming 1.4 times more prey than on sour orange ( 0.08 versus 0.11 ppic in Cleopatra mandarin and sour orange, respectively). Therefore, sour orange clearly offers a better quality prey for this specialist predator.

\subsubsection{GLVs are widely present in phytoseiid scents but monoterpenes are not associated to $E$. stipulatus}

From the 21 different volatiles observed in the blends associated with phytoseiids (Table 3.3, 3.4 and 3.5), only the Green Leaf Volatile (GLV, Tanaka et al., 2018) hexanol (with the alcohol group in different positions) was consistently found in the odors of three phytoseiid species. Another GLV, 2-hexanone, was present in N. californicus and P. persimilis. The remaining compounds were associated with one species only. In the case of E. stipulatus, these were six additional GLVs (including in this group not only C6 but also C8 and C9 aldehydes, alcohols, and esters), which were regularly identified irrespective of the rearing substrate (either bean or citrus detached leaf colonies). For the other two phytoseiids, no more GLVs were observed but instead up to 10 different monoterpenes in P. persimilis, which accounted for more than $85 \%$ of the blend, and just one, geraniol (25\% of the blend) in $N$. californicus. 
Table 3.3 Compounds detected in volatile collections of E. stipulatus (relative mean \pm standard error $^{1}$ percentage considering the total chromatogram area of the detected compounds) reared on detached bean leaves.

\begin{tabular}{lcccc}
\hline Compound & id. $^{\mathbf{2}}$ & rt (min) & Mean & Se \\
\hline 1-hexanol & $\mathrm{C}$ & 9.47 & 2.59 & 0.86 \\
1-octen-3-ol & $\mathrm{C}$ & 13.53 & 56.96 & 3.04 \\
3-octanone & $\mathrm{T}$ & 13.64 & 36.28 & 2.21 \\
3-octanol & $\mathrm{T}$ & 14.08 & 0.82 & 0.25 \\
2-octen-1-ol & $\mathrm{T}$ & 16.82 & 0.72 & 0.23 \\
3-nonen-1-ol & $\mathrm{T}$ & 19.58 & 1.78 & 0.80 \\
1-nonanol & $\mathrm{C}$ & 20.08 & 0.85 & 0.43
\end{tabular}

${ }^{1}$ Means of six replicates of individuals collected in two different stock colonies maintained in the laboratory, three on citrus and the other three one on bean leaves.

${ }^{2}$ Identification of the compound: C, confirmed with commercial standard; T, tentative with spectra and high probability matches (>80\%) according to NIST mass spectral database (Wallis et al., 2008).

Table 3.4 Compounds detected in volatile collections of $N$. californicus (relative mean \pm standard error ${ }^{1}$ percentage considering the total chromatogram area of the detected compounds) obtained from a commercial supplier.

\begin{tabular}{lcccc}
\hline Compound & id. $^{\mathbf{2}}$ & rt (min) & mean & se \\
\hline 2-hexanone & C & 6.55 & 21.83 & 4.50 \\
3-hexanol & C & 6.91 & 4.57 & 0.98 \\
2-hexanol & C & 7.02 & 48.28 & 7.31 \\
geranyl formate & T & 23.19 & 25.33 & 8.90
\end{tabular}

${ }^{1}$ Means of nine replicates of individuals obtained from three different shipments.

${ }^{2}$ Identification of the compound: $\mathrm{C}$, confirmed with commercial standard; $\mathrm{T}$, tentative with spectra and high probability matches (>80\%) according to NIST mass spectral database (Wallis et al., 2008).

Table 3.5 Compounds detected in volatile collections of $P$. persimilis (relative mean \pm standard error $^{1}$ percentage considering the total chromatogram area of the detected compounds) obtained from a commercial supplier.

\begin{tabular}{lcccc}
\hline Compound & id. $^{2}$ & rt (min) & mean & se \\
\hline 2-hexanone & $\mathrm{C}$ & 6.55 & 11.90 & 3.68 \\
2-hexanol & $\mathrm{C}$ & 7.14 & 5.57 & 1.39 \\
3-thujene & $\mathrm{T}$ & 11.69 & 0.20 & 0.05 \\
1-isopropyl-4-methylenebicyclo[3.1.0]hex-2-ene & $\mathrm{T}$ & 12.47 & 0.45 & 0.11 \\
Fenchone & $\mathrm{C}$ & 17.31 & 1.42 & 0.25 \\
pinocarveol & $\mathrm{T}$ & 19.19 & 0.94 & 0.15 \\
\hline
\end{tabular}




\begin{tabular}{lcccc}
\hline Camphor & $\mathrm{C}$ & 19.35 & 1.66 & 0.33 \\
$\beta$-terpineol & $\mathrm{T}$ & 19.64 & 0.46 & 0.07 \\
Borneol & $\mathrm{C}$ & 20.19 & 3.62 & 0.30 \\
4 -terpineol & $\mathrm{C}$ & 20.41 & 11.51 & 1.67 \\
$\alpha$-terpineol isomer & $\mathrm{T}$ & 20.66 & 7.27 & 3.03 \\
$\alpha$-terpineol isomer & $\mathrm{T}$ & 20.89 & 54.99 & 2.56
\end{tabular}

${ }^{1}$ Means of nine replicates of individuals obtained from three different shipments.

${ }^{2}$ Identification of the compound: C, confirmed with commercial standard; T, tentative with spectra and high probability matches (>80\%) according to NIST mass spectral database (Wallis et al., 2008).

\subsection{Discussion}

Our results have shown that the volatile signature of the three phytoseiids included in our study is species specific and different from the shared prey, T. urticae, where a mixture of GLVs, monoterpenes, aromatic compounds and methyl salicylate (MeSA) was identified (Cabedo-López et al., 2019). These secondary metabolites are widely found in plants (Beran et al., 2019) and their sequestration by phytophagous arthropods for their own defense or communication is well documented (Opitz and Müller, 2009). Therefore, mites may take these secondary metabolites from the host plant, either directly (T. urticae and E. stipulatus) or indirectly through their phytophagous prey (i.e., the three phytoseiid species). Interestingly, some astigmatid mites (Acari: Acaridae), which are commonly used as prey in mass production of predatory mites, can also synthesize some monoterpenes (Morgan et al., 2010; Beran et al., 2019). Monoterpenes were absent in the blend associated with the plant cell-sap feeding E. stipulatus but constituted the major component of that produced by the strict entomophagous $P$. persimilis. Moreover, one single monoterpene was present but not predominant in the scent of $N$. californicus, which presents an intermediate diet specialization. Same as in E. stipulatus, GLVs prevail in $N$. californicus-associated scent (Tables 3.3 and 3.4). How these chemical cues, which are linked to risk perception, may have been exploited by the species that compose this community is discussed below.

Plant response to herbivory includes the release of GLVs, terpenoids, nitrogen-containing nitriles and oximes, and MeSA, among other herbivore plant induced volatiles (HIPVs), which play a crucial role in mediating the behavior of phytophagous arthropods and their natural enemies and also in plant-to-plant communication (Dudareva et al., 2006; Wei and Kang, 2011; Tanaka et al., 2018). Indeed, the HIPVs released by T. urticae-infested 
sour orange, where MeSA represents more than $50 \%$ of the blend, can induce resistance in Cleopatra mandarin (Agut et al., 2015; Cabedo-López et al., 2019). Interestingly, none of the HIPVs identified in these citrus genotypes (Agut et al., 2015; Cabedo-López et al., 2019) could be found in the odors associated with phytoseiids although MeSA had been identified in the odors of T. urticae (Cabedo-López et al., 2019). Likewise, none of the HIPVs identified in the same citrus genotypes when occupied by E. stipulatus or $N$. californicus (Cruz-Miralles et al., 2019), respectively was found in the odors associated with phytoseiids. Because the origin of these volatiles is most probably the host plant, these results were unexpected. One possible explanation is that the amounts of the volatiles associated with mites are orders of magnitude below those produced by plants, as we were unable to detect MeSA in T. urticae using the same methods used for plant HIPVs (Cabedo-López et al., 2019). One additional explanation for these results is the origin of phytoseiid stock colonies used for odor extraction. In the cases of $N$. californicus and $P$. persimilis, the rearing substrate remains unknown but does not include citrus and most probably uses astigmatid mites as prey (Bolckmans and van Houten, 2006). As mentioned earlier astigmatid mites are among those arthropods which can synthetize monoterpenes and sesquiterpenes (Morgan et al., 2010; Beran et al., 2019), which can be used in defense (alarm pheromones) or attraction (aggregation- and sex-pheromones) (Kuwahara, 2004). However, this was not the case of E. stipulatus, where the same chromatographic peaks were observed independently of whether the mite had been obtained from colonies maintained on citrus or bean leaves (Table 3.3). Therefore, these results may be taken as evidence of a selective sequestration of GLVs from plant HIPVs by E. stipulatus independently of the host plant.

Whether, similar to the scent of entomopathogenic nematodes, phytoseiid odors can modify plant defense (Helms et al., 2019) deserves further research. This could be a plausible explanation for the changes in the regulation of LOX2 and CHS observed in Cleopatra mandarin and sour orange, respectively, upon occupation by $N$. californicus, as this mite does not engage in plant cell-sap feeding (Adar et al., 2012). Potential ecological explanations for such an effect include plants mistakenly perceiving phytoseiids as a direct threat from an herbivore and plants using phytoseiid cues as an indication of an imminent risk of herbivory. However, neither Cleopatra mandarin nor sour orange responded to the strict entomophagous $P$. persimilis (Cruz-Miralles et al., submitted). Therefore, citrus plants can discriminate at least between these two phytoseiid species. 
This could be based on their different volatile profile and linked to the higher voracity of specialized predators of the genus Tetranychus spp., like $P$. persimilis, compared to those specialized in tetranychids, like N. californicus (Table 3.2) (McMurtry et al., 2013). This would finally result in relatively higher fitness of plants where T. urticae is regulated by $P$. persimilis, which would be recruited by the plant at no additional cost, compared to either $N$. californicus, recruited at the expense of modifications in the regulation of defense genes (Cruz-Miralles et al., submitted), or E. stipulatus, which is the less voracious phytoseiid from the three studied (Table 3.2) and has a cost for the plant in form of feeding damage (i.e., zoophytophagy), changes in the regulation of defense genes and prey attraction (Cruz-Miralles et al., 2019). Although the latter may be seen as a negative effect for the plant, it does not need to be so. In fact, E. stipulatus is considered as a poor performing predator on well-established T. urticae colonies because of its inability to enter and move within T. urticae dense webs (Sabelis and Bakker, 1992). Therefore, it should perform much better on arriving or recently established immigrant $T$. urticae specimens. This would justify its selection by Grafton-Cardwell et al. (1997) as an efficient biological control agent against $T$. urticae in citrus nurseries. As a consequence, E. stipulatus is the only phytoseiid from the three considered herein for which non-negative effects from attraction to unoccupied plants can be anticipated. This plant-predator interaction could provide support to the occurrence of mutualism between first and third trophic levels, a controversial issue (Heil et al., 2008; van der Meijden and Klinkhamer, 2000), which remains doubtful for the other two predators.

Cabedo-López et al. (2019) (Table 3.6) checked the preferences of the three phytoseiids for T. urticae and concluded that they could successfully identify T. urticae odors and, as expected, preferred T. urticae-infested plants to clean plants. This is an important aspect of this tri-trophic interaction because otherwise plant-predator mutualism would be highly unstable (Turlings and Ton, 2006). Only in the case of E. stipulatus the plant genotype affected the choice and Cleopatra mandarin was preferred to sour orange when both genotypes were occupied by the herbivore. This result could be explained by the plant cell-sap feeding habits of this omnivore, which would benefit from feeding on the less defended plant (Agut et al., 2014), as proven by the profitability assay (Table 3.2). T. urticae could also perceive the risk associated with the scents of its potential predators and avoided them (Cruz-Miralles et al., 2019) (Table 3.6). Same as before, this distinction could be based on the species-specific smell of phytoseiids (Tables 3.3, 3.4 and 3.5). The 
perception of predation risk by T. urticae when predators were occupying citrus though changed for E. stipulatus. Occupied plants became attractive for T. urticae irrespective of the citrus genotype. The results of the profitability assays, where almost half of the replicates involving E. stipulatus showed increasing T. urticae densities after introduction of this phytoseiid while the other half showed decreases much smaller than those observed for the other two phytoseiids (Table 3.2), support the hypotheses that E. stipulatus poses a relatively low predation risk to $T$. urticae and that it has a marked preference for other food resources, including plant cell-sap feeding, as confirmed by gut-content analyses of E. stipulatus field-collected specimens (Pérez-Sayas et al., 2015).

Our results prove that the three phytoseiids studied can also distinguish the odors of both conspecifics and heterospecifics as their behavior changed depending not only on these scents but also on the background smell (i.e., no plant, sour orange or Cleopatra mandarin) (Figures 3.2, 3.3 and 3.4). Our expectations were that the strongest IG opponent would trigger repellence in heterospecifics. According to Abad-Moyano et al. (2010) this species is E. stipulatus. However, Urbaneja-Bernat et al. (2019) pointed at P. persimilis. Interestingly, the origin of the stock colony of $P$. persimilis used in our assays coincides with Urbaneja-Bernat et al. (2019) but differs from Abad-Moyano et al. (2010), who purchased it from the same company as N. californicus. Accordingly, our results also point at $P$. persmilis as the strongest IG opponent. On the one hand, $P$. persmilis is the only phytoseiid whose choices do not depend on the presence of heterospecifics on the plant (Figures 3.4b and 3.4c) and this can be interpreted as $P$. persimilis perceiving heterospecific smells as low risk cues. However, its presence, at least on sour orange, repelled both E. stipulatus (Figures 3.2b and 3.2c) and N. californicus (Figures 3.3b and $3.3 \mathrm{c}$ ), which means that both phytoseiids perceive $P$. persmilis odors as high risk cues. Intriguingly, though the same presence became attractive in Cleopatra mandarin, which highlights the importance of the background volatile blend. As both Abad-Moyano et al. (2010) and Urbaneja-Bernat et al. (2019) used the same plant genotype in their assays (young plants of Citrus clementina Tanaka cv. Clementina de Nules grafted on citrange Carrizo), it would be interesting to check the effect of plant genotype on phytoseiid IG interactions. Actually, Gish et al (2015) proved that HIPV-mediated ecological interactions may be altered by anthropogenic environmental change including cues from novel plants. 


\subsection{Conclusions}

To sum up, our results show a diversity of ecological roles of plant, herbivore and carnivore scents, which may have contributed to shaping this community. The multifunctionality of most of these cues and their interdependence opens new questions that should be addressed in the future. Only a thorough understanding of these interactions will enhance our ability to predict and manage these and more complex systems.

Table 3.6 Results of 2-choice tests. Individual mites could choose between two odor sources, which could be an empty flask (Ø), a bag containing 25 mites (mite), or a Cleopatra mandarin or a sour orange plant, either clean (CMø, $\mathrm{SO}_{\varnothing}$, respectively) or occupied $\left(\mathrm{CM}_{\text {mite }}, \mathrm{SO}_{\text {mite, }}\right.$ respectively). 40 females per combination were tested. Occupied plants were exposed to 25 females for 48 hours prior to the onset of the assay.

\begin{tabular}{|c|c|c|c|c|c|}
\hline \multirow[b]{3}{*}{ Choosing mite } & \multicolumn{5}{|l|}{ Odor sources } \\
\hline & \multirow{2}{*}{ Combination } & \multicolumn{4}{|c|}{ Mite species } \\
\hline & & T. urticae & E. stipulates & N. californicus & P. persimilis \\
\hline \multirow[t]{5}{*}{ T. urticae } & mite vs Ø & I (3) & $\varnothing(2)$ & $\varnothing(4)$ & $\varnothing(4)$ \\
\hline & $\mathrm{SO}_{\varnothing}$ vs $\mathrm{CM}_{\varnothing}$ & $\mathrm{CM}_{\varnothing}(1,3)$ & $\mathrm{CM}_{\varnothing}(1,3)$ & $\mathrm{CM}_{\varnothing}(1,3)$ & $\mathrm{CM}_{\varnothing}(1,3)$ \\
\hline & $\mathbf{S O}_{\text {mite }} \mathbf{V S} \mathbf{S O}_{\varnothing}$ & $\mathrm{SO}_{\varnothing}(1,3)$ & $\mathrm{SO}_{E . ~ s t i p u l a t u s}(2)$ & $\mathrm{SO}_{\varnothing}(4)$ & $\mathrm{SO}_{\varnothing}(4)$ \\
\hline & $\mathbf{C M}_{\text {mite }}$ vs $\mathbf{C} \mathbf{M}_{\varnothing}$ & $\mathrm{CM}_{\text {T. urticae }}(1,3)$ & $\mathrm{CM}_{\text {E. stipulatus }}(2)$ & $\mathrm{CM}_{\varnothing}(4)$ & $\mathrm{CM}_{\varnothing}(4)$ \\
\hline & $\mathbf{S O}_{\text {mite }}$ vs $\mathbf{C M}_{\text {mite }}$ & $\mathrm{CM}_{\text {T. urticae }}(1,3)$ & $\mathrm{I}(2)$ & $\mathrm{I}(4)$ & $\mathrm{I}(4)$ \\
\hline \multirow[t]{5}{*}{ E. stipulates } & mite vs Ø & T. urticae (3) & E. stipulatus (2) & N. californicus (5) & $\varnothing(5)$ \\
\hline & SOø vs CM$_{\varnothing}$ & $\mathrm{SO}_{\varnothing}(2)$ & $\mathrm{SO}_{\varnothing}(2)$ & $\mathrm{SO}_{\varnothing}(2)$ & $\mathrm{SO}_{\varnothing}(2)$ \\
\hline & $\mathbf{S O}_{\text {mite }} \mathbf{v s} \mathbf{S O}_{\varnothing}$ & $\mathrm{SO}_{T . \text { urticae }}(3)$ & $\mathrm{SO}_{\varnothing}(2)$ & $\mathrm{I}(5)$ & $\mathrm{SO}_{\varnothing}(5)$ \\
\hline & $\mathbf{C} \mathbf{M}_{\text {mite }}$ vs $\mathbf{C} \mathbf{M}_{\varnothing}$ & $\mathrm{CM}_{\text {T. urticae }}(3)$ & $\mathrm{CM}_{\text {E. stipulatus }}$ (2) & $\mathrm{CM}_{N . \text { californicus }}(5)$ & $\mathrm{CM}_{P . \text { persimilis }}(5)$ \\
\hline & $\mathbf{S O}_{\text {mite }}$ vs $\mathbf{C M}_{\text {mite }}$ & $\mathrm{CM}_{\text {T. urticae }}(3)$ & $\mathrm{CM}_{\text {E. stipulatus }}(2)$ & $\mathrm{CM}_{N . \text { californicus }}(5)$ & $\mathrm{CM}_{P . \text { persimilis }}(5)$ \\
\hline \multirow[t]{5}{*}{ N. californicus } & mite vs Ø & T. urticae (3) & E. stipulatus (5) & $\varnothing(4)$ & P. persimilis (5) \\
\hline & $\mathbf{S O}_{\varnothing}$ vs CMø & $\mathrm{SO}_{\varnothing}(4)$ & $\mathrm{SO}_{\varnothing}(4)$ & $\mathrm{SO}_{\varnothing}(4)$ & $\mathrm{SO} \varnothing(4)$ \\
\hline & $\mathbf{S O}_{\text {mite }} \mathbf{V S} \mathbf{S O}_{\varnothing}$ & $\mathrm{SO}_{\text {T. urticae }}(3)$ & $\mathrm{SO}_{\varnothing}(5)$ & I (4) & $\mathrm{SO}_{\varnothing}(5)$ \\
\hline & $\mathbf{C} \mathbf{M}_{\text {mite }}$ vs $\mathbf{C} \mathbf{M}_{\varnothing}$ & $\mathrm{CM}_{T \text {. urticae }}(3)$ & $\mathrm{CM}_{\text {E. stipulatus }}$ (5) & I (4) & $\mathrm{CM}_{P . \text { persimilis }}(5)$ \\
\hline & $\mathbf{S O}_{\text {mite }}$ vs $\mathbf{C M}_{\text {mite }}$ & $\mathrm{I}(3)$ & $\mathrm{CM}_{\text {E. stipulatus }}(5)$ & I (4) & $\mathrm{CM}_{P \text {. persimilis }}(5)$ \\
\hline \multirow[t]{5}{*}{$P$. persimilis } & mite vs Ø & T. urticae (3) & I (5) & I (5) & I (4) \\
\hline & $\mathbf{S O}_{\varnothing}$ vs $\mathbf{C M}_{\varnothing}$ & $\mathrm{SO}_{\varnothing}(4)$ & $\mathrm{SO}_{\varnothing}(4)$ & $\mathrm{SO}_{\varnothing}(4)$ & $\mathrm{SO}_{\emptyset}(4)$ \\
\hline & $\mathbf{S O}_{\text {mite }} \mathbf{V S} \mathbf{S O}_{\varnothing}$ & $\mathrm{SO}_{T . \text { urticae }}(3)$ & $\mathrm{I}(5)$ & $\mathrm{I}(5)$ & $\mathrm{SO}_{\varnothing}(4)$ \\
\hline & $\mathbf{C M}_{\text {mite }}$ vs $\mathbf{C} \mathbf{M}_{\varnothing}$ & $\mathrm{CM}_{\text {T. urticae }}(3)$ & I (5) & I (5) & $\mathrm{I}(4)$ \\
\hline & $\mathbf{S O}_{\text {mite }}$ vs $\mathbf{C} \mathbf{M}_{\text {mite }}$ & $\mathrm{I}(3)$ & I (5) & I (5) & $\mathrm{CM}_{P . \text { persimilis }}(4)$ \\
\hline
\end{tabular}

$\mathrm{I}=$ indiference

Sources in brackets: 1: Agut et al., 2015; 2: Cruz-Miralles et al. 2019; 3: Cabedo-López et al., 2019; 4: Chapter2; 5: this chapter 

DISCUSIÓN GENERAL 

Algunos autores han demostrado que algunas chinches zoofitófagas de las familias Miridae y Anthocoridae (Hemiptera: Heteroptera), que constituyen un importante grupo de agentes de control biológico, pueden afectar significativamente a sus presas no solo por la depredación directa, sino mediante la inducción de respuestas defensivas en las plantas huésped (Arnó et al., 2009; De Puysseleyr et al., 2011; Perdikis et al., 2011; Messelink et al., 2015; Pappas et al., 2015; Pérez-Hedo et al., 2015; Naselli et al., 2016; Bouagga et al., 2018; Zhang et al., 2018). Los resultados de esta tesis demuestran que los ácaros fitoseidos también son capaces de inducir este tipo de respuestas en cítricos, al menos en condiciones de laboratorio. Estas respuestas dependen tanto del grado de especialización alimenticia del fitoseido, como del genotipo de la planta y su interacción con la presa, y además de sobre el primer nivel trófico, pueden tener consecuencias en niveles superiores (herbívoros y carnívoros).

En primer lugar, se estudió la relación entre el ácaro zoofitófago Euseius stipulatus, el naranjo amargo (Citrus aurantium) y el mandarino clementino (C. reshni), dos cítricos con distinto nivel de resistencia a la herbivoría por la araña roja, Tetranychus urticae (Agut et al., 2016), y la propia T. urticae (Capítulo 1). A continuación, se completó el estudio con los otros dos ácaros depredadores, Neoseiulus californicus y Phytoseiulus persimilis, que comparten nicho con las especies anteriores (Aguilar-Fenollosa et al., 2011 b; Vela et al., 2017), pero que presentan dietas menos amplias, siendo el primero un omnívoro especializado en tetraníquidos, y el segundo un depredador especialista en el género Tetranychus spp. (McMurtry et al., 2013) (Capítulo 2). Por último, se caracterizaron los volátiles liberados por cada uno de los tres fitoseidos, y los efectos de esos volátiles para estos depredadores, así como el valor de la presa T. urticae en función de la planta donde se alimentó (C. aurantium frente a C. reshni) (Capítulo 3). Todo ello, nos ha permitido concluir que (1) las plantas son capaces de percibir y distinguir los olores de los fitoseidos, y responder de forma diferenciada mediante la activación de determinadas vías de defensa que incluyen la liberación de nuevos volátiles; (2) la presa es también capaz de percibir y distinguir esos olores y modificar su comportamiento; y (3) los depredadores también pueden percibir y distinguir los volátiles producidos tanto por plantas como por herbívoros y otros depredadores, y modificar su comportamiento. A continuación, veremos cómo este sistema ha explotado estas señales químicas directamente ligadas a la percepción del riesgo, y cómo podríamos explotarlas para mejorar el control biológico de plagas agrícolas. 
Tanto E. stipulatus como N. californicus fueron capaces de inducir respuestas de defensa en planta que dependen del genotipo de esta última (Figuras 1.4 y 2.3, respectivamente). Sin embargo, P. persimilis no originó ningún cambio de este tipo. Hasta donde nosotros sabemos, esta es la primera vez que este tipo de efecto se ha descrito para un fitoseido. Aunque la explicación más razonable para los resultados observados en E. stipulatus es que esta respuesta vaya ligada a sus hábitos zoofitófagos, que incluyen la ingesta de alimento líquido de la planta huésped (Adar et al., 2012; McMurtry et al., 2013), en el caso de N. californicus, estos deberían ir ligados a otros factores de naturaleza mecánica (desplazamiento, puesta, excreción) y/o química (el propio olor del fitoseido), ya que parece que este fitoseido no puede alimentarse directamente de la planta (Adar et al., 2012). E. stipulatus indujo en C. aurantium la activación de las vías de defensa del ácido jasmónico (JA), del salicílico (SA) y de los flavonoides (Figura 1.3), las mismas que $T$. urticae (Agut et al., 2014) aunque en menor grado, mientras que en C. reshni solo indujo la del JA y se reprimió la de los flavonoides (Figura 1.3), contrario a lo observado para T. urticae, que indujo en este genotipo la vía del SA (Agut et al., 2014). Las diferencias entre el tipo daño provocado por T. urticae, que se alimenta de las células del mesófilo evitando dañar las de la epidermis (Bensoussan et al., 2016), y E. stipulatus, que presumiblemente se alimenta precisamente de las células epidérmicas (Adar et al., 2012) podrían explicar las diferencias observadas. Curiosamente, N. californicus indujo la represión de la vía de los flavonoides en $C$. aurantium y activó la del JA en $C$. reshni (Figura 2.4) en un orden de magnitud parecido a los observados para E. stipulatus, pero muy por debajo de los provocados por T. urticae (Agut et al., 2014). Estos resultados, junto con la constatación de que los volátiles producidos por los fitoseidos son específicos de cada uno de ellos (Tablas 3.3, 3.4 y 3.5), son los que nos permiten concluir que 'las plantas son capaces de percibir y distinguir los olores de los fitoseidos, y responder de forma diferenciada mediante la activación de determinadas vías de defensa que incluyen la liberación de nuevos volátiles'. No queda claro si estas respuestas se deben a la percepción de los fitoseidos como herbívoros (podría ser el caso del zoofitófago $E$. stipulatus) o como señal de un riesgo inminente de herbivoría. En cualquier caso, estos resultados podrían explotarse para mejorar la regulación natural de las poblaciones de $T$. urticae en cítricos, a través de la activación de las defensas de la propia planta, ya fuera mediante la suelta y/o la conservación de E. stipulatus, que se puede criar fácilmente con alimento alternativo (Pina et al., 2012) y podría sobrevivir en campo aún sin su presa, o la utilización de los volátiles identificados en E. stipulatus o en $N$. californicus, que 
podrían contribuir a preparar la planta para un futuro ataque de T. urticae (primming, Pastor et al., 2014).

Sabíamos por estudios anteriores (Agut et al., 2015), que T. urticae podía distinguir entre los dos genotipos de cítrico estudiados en esta tesis y dirigirse hacia el que ofrecía menor resistencia (Agut et al., 2014). Ahora sabemos que también es capaz de distinguir los olores asociados a sus tres depredadores potenciales y, como era de esperar, huir de ellos (Figuras 1.1 y 2.1). Sin embargo, este comportamiento se puede ver alterado cuando los depredadores están en la planta. Por ello, hemos concluido que 'la presa es también capaz de percibir y distinguir esos olores y modificar su comportamiento'. Quizás el resultado más interesante en lo relativo a este segundo nivel trófico es el cambio observado para $E$. stipulatus, que resulta atractivo para la presa independientemente del genotipo de la planta donde se encuentre (Figura 1.1). Ello podría explicarse por el relativamente bajo riesgo de depredación que supone este fitoseido para T. urticae respecto a los otros dos (Tabla 3.2). El hecho de que este depredador se considere especialmente efectivo antes de que las telarañas que suelen acompañar el desarrollo de las colonias de T. urticae impidan su acceso a las mismas (Sabelis and Bakker, 1992), justificaría la importancia de la conservación de este fitoseido, especialmente en primavera, cuando las condiciones ambientales le son especialmente favorables (Urbaneja-Bernat et al., 2019), para prevenir futuras explosiones de la araña. Los volátiles identificados para los tres fitoseidos podrían, además, explotarse en estrategias de push-and-pull (Cook et al., 2007), aunque habría que seguir investigando. En este mismo grupo, habría que incluir al cineol, terpenoide cuya producción disminuyó con la infestación por E. stipulatus (Tabla 1.1), y que, por tanto, también podría jugar un papel clave en la atracción de $T$. urticae, y que debería ser estudiado más a fondo.

Nuestros resultados nos han permitido concluir que 'los depredadores también pueden percibir y distinguir los volátiles producidos tanto por plantas como por herbívoros y otros depredadores y modificar su comportamiento'. En general, los depredadores, contrariamente a lo esperado, se vieron atraídos por las plantas con mayores niveles de defensa (Figuras 1.2, 2.2 , 3.2, 3.3 y 3.4), que parece que estos interpretan como señal de infestación por la presa. Puesto que el único fitoseido para el que esta atracción no supone un efecto negativo es E. stipulatus, que puede alimentarse de la planta cuando su presa no está presente, este caso podría suponer una evidencia de la existencia de mutualismo entre el primer y el tercer nivel trófico, un fenómeno que aún suscita controversia (Heil 
et al., 2008; van der Meijden and Klinkhamer, 2000) y que no queda totalmente claro para los otros dos fitoseidos estudiados. Con todo, los tres depredadores se vieron atraídos por los olores de su presa, aunque esta atracción se moduló cuando T. urticae estaba sobre la planta, pero no para seleccionar la planta con menor defensa directa, donde se presuponen mayores densidades de la presa (Agut et al., 2014), lo que refuerza la hipótesis de que los depredadores interpretan mayores niveles de defensa directa como signo de infestación por el hebívoro. Finalmente, el comportamiento observado frente a los olores de plantas ocupadas por potenciales competidores intragremiales, indica que $P$. persimilis es percibido como el depredador potencialmente más competitivo, algo que coincide con los resultados obtenidos por Urbaneja-Bernat y colaboradores (2019). A pesar de ello, E. stipulatus sigue siendo la especie de fitoseido más abundante en el sistema estudiado en condiciones de campo (Aguilar-Fenollosa et al., 2011b; Vela et al., 2017), lo cual puede ir ligado a su habilidad para desarrollarse y reproducirse sobre múltiples fuentes de alimento que no van ligadas directamente a la presencia de su presa (Pina et al., 2012). 
CONCLUSIONES 

1. Los ácaros fitoseidos pueden desencadenar respuestas defensivas en las plantas. Estas dependen de los hábitos alimenticios del depredador, incluida la zoofitofagia de algunos generalistas omnívoros. Este es el caso de Euseius stipulatus. Sin embargo, otros factores, tanto de naturaleza mecánica (el desplazamineto, la puesta, la excreción), como química (secreciones, volátiles asociados), podrían ser los desencadenantes de este tipo de respuesta en especies que no se alimentan de la planta huésped. Este es el caso de Neoseiulus californicus.

2. El depredador zoofitófago E. stipulatus es capaz de activar distintas rutas metabólicas en los cítricos, desencadenando la liberación de compuestos volátiles. Dichos cambios en las respuestas defensivas de los cítricos inducidos por el ácaro (activación de genes y liberación de mezclas volátiles) dependen del genotipo de la planta. Pueden, además, alterar el comportamiento de elección tanto del herbívoro presa Tetranychus urticae, como el de los conespecíficos.

3. Los depredadores especialistas de tetraníquidos $N$. californicus y P. persimilis presentan distinta capacidad inductora sobre las plantas de cítrico. N. californicus es capaz de activar la defensa de la planta de forma similar a como lo hace $E$. stipulatus. La presencia de ambos depredadores en las plantas hace que estas resulten repelentes para el fitófago. Finalmente, no se detectó ninguna respuesta en los cítricos por la presencia del depredador P. persimilis.

4. Los tres ácaros fitoseidos del presente estudio liberan distintos grupos de compuestos volátiles en función del nivel de especialización de sus dietas. Para el caso de E. stipulatus, los compuestos liberados por el propio ácaro fueron 'Green Leaf Volatiles' (GLV). Para el caso de N. californicus, aunque la mayoría de los compuestos caracterizados también fueron GLV, se detectó uno perteneciente al grupo de los terpenoides (geraniol). Finalmente, el ácaro más especialista de $T$. urticae, $P$. persimilis, sólo produjo compuestos orgánicos del grupo de los monoterpenos. En cuanto al ensayo sobre el aprovechamiento, el factor determinante para el zoofitófago E. stipulatus fue la planta y no la presa (depredación), ya que se observaron mayores poblaciones del fitoseido sobre el patrón mandarino Cleopatra. Para N. calfornicus, el único factor determinante fue 
el factor depredación. Las poblaciones de este depredador fueron mayores en naranjo amargo. Finalmente, en el caso de $P$. persimilis, fue determinante el factor genotipo de la planta, la depredación y la interacción. En este caso, hubo mayor densidad de población del fitoseido en mandarino Cleopatra, al igual que una mayor depredación de arañas alimentadas sobre este patrón. Los ensayos de elección entre depredadores con la presencia de las plantas de cítrico o sin ellas nos hace indicar que el depredador $P$. persimilis es el fitoseido superior de los tres estudiados. 
BIBLIOGRAFÍA 

Abad-Moyano, R. A., Aguilar-Fenollosa, E. A., \& Pascual-Ruiz, S. (2008). Control biológico de ácaros. In Jacas J.A. \& Urbaneja A. (Eds), Control biológico de plagas agrícolas (pp. 151-164). Spain. Phytoma.

Abad-Moyano, R., Pina, T., Dembilio, O., Ferragut, F., \& Urbaneja, A. (2009a). Survey of natural enemies of spider mites (Acari: Tetranychidae) in citrus orchards in eastern Spain. Experimental and Applied Acarology, 47(1), 49-61.

Abad-Moyano, R., Pina, T., Ferragut, F., \& Urbaneja, A. (2009b). Comparative lifehistory traits of three phytoseiid mites associated with Tetranychus urticae (Acari: Tetranychidae) colonies in clementine orchards in eastern Spain: implications for biological control. Experimental and Applied Acarology, 47(2), 121-132.

Abad-Moyano, R., Pina, T., Pérez-Panadés, J., Carbonell, E. A., \& Urbaneja, A. (2010a). Efficacy of Neoseiulus californicus and Phytoseiulus persimilis in suppression of Tetranychus urticae in young clementine plants. Experimental and Applied Acarology, 50(4), 317-328.

Abad-Moyano, R., Urbaneja, A., Hoffmann, D., \& Schausberger, P. (2010b). Effects of Euseius stipulatus on establishment and efficacy in spider mite suppression of Neoseiulus californicus and Phytoseiulus persimilis in clementine. Experimental and Applied Acarology, 50(4), 329-341.

Abd El-Samad, M.A., El-Halawany, M.E., \& El-Saied, K.M. (1996). Utilizing Euseius scutalis Athias-Henriot to control Eutetranychus orientalis Klein on citrus trees. Egyptian Journal of Agriculutral Research, 74(3), 671-684.

Adar, E., Inbar, M., Gal, S., Doron, N., Zhang, Z. Q., \& Palevsky, E. (2012). Plantfeeding and non-plant feeding phytoseiids: differences in behavior and cheliceral morphology. Experimental and Applied Acarology, 58(4), 341-357.

Adar, E., Inbar, M., Gal, S., Issman, L. and Palevsky, E. (2015). Plant cell piercing by a predatory mite: evidence and implications. Experimental and Applied Acarology, 65, 181-193.

Aguilar-Fenollosa, E., Ibáñez-Gual, M. V., Pascual-Ruiz, S., Hurtado, M., \& Jacas, J. A. (2011a). Effect of ground-cover management on spider mites and their phytoseiid natural enemies in clementine mandarin orchards (I): bottom-up regulation mechanisms. Biological Control, 59(2), 158-170. 
Aguilar-Fenollosa, E., Ibáñez-Gual, M. V., Pascual-Ruiz, S., Hurtado, M., \& Jacas, J. A. (2011b). Effect of Ground-Cover Management on Spider Mites and their Phytoseiid Natural Enemies in Clementine Mandarin Orchards (II): Top-down regulation mechanisms. Biological Control, 59, 171-179.

Aguilar-Fenollosa, E., Pascual-Ruiz, S., Hurtado, M. A., \& Jacas, J. A. (2011c). Efficacy and economics of ground cover management as a conservation biological control strategy against Tetranychus urticae in clementine mandarin orchards. Crop Protection, 30(10), 1328-1333.

Aguilar-Fenollosa, E., Pina, T., Gómez-Martínez, M. A., Hurtado, M. A., \& Jacas, J. A. (2012). Does host adaptation of Tetranychus urticae populations in clementine orchards with a Festuca arundinacea cover contribute to a better natural regulation of this pest mite? Entomologia Experimentalis et Applicata, 144,181-190.

Agut, B., Gamir, J., Jacas, J. A., Hurtado, M., \& Flors, V. (2014). Different metabolic and genetic responses in citrus may explain relative susceptibility to Tetranychus urticae. Pest Management Science, 70(11), 1728-1741.

Agut, B., Gamir, J., Jaques, J. A., \& Flors, V. (2015). Tetranychus urticae-triggered responses promote genotype-dependent conspecific repellence or attractiveness in citrus. New Phytologist, 207(3), 790-804.

Agut, B., Gamir, J., Jaques, J. A., \& Flors, V. (2016). Systemic resistance in citrus to Tetranychus urticae induced by conspecifics is transmitted by grafting and mediated by mobile amino acids. Journal of Experimental Botany, 67(19), 5711-5723.

Alfaro, C., Vacas, S., Zarzo, M., Navarro-Llopis, V., \& Primo, J. (2011). Solid phase microextraction of volatile emissions of Ceratitis capitata (Wiedemann) (Diptera: Tephritidae): influence of sex, age, and mating status. Journal of Agricultural and Food Chemistry, 59(1), 298-306.

Argolo, P. S., Banyuls, N., Santiago, S., Mollá, Ó., Jacas, J. A., \& Urbaneja, A. (2013). Compatibility of Phytoseiulus persimilis and Neoseiulus californicus (Acari: Phytoseiidae) with imidacloprid to manage clementine nursery pests. Crop Protection, $43,175-182$. 
Argolo, P. S., Jacas, J. A., \& Urbaneja, A. (2014). Comparative toxicity of pesticides in three phytoseiid mites with different life-style occurring in citrus: Euseius stipulatus, Neoseiulus californicus and Phytoseiulus persimilis. Experimental and Applied Acarology, 62(1), 33-46.

Arnó, J., Gabarra, R., Liu, T. X., Simmons, A. M., \& Gerling, D. (2009). Natural enemies of Bemisia tabaci: predators and parasitoids. In Bemisia: bionomics and management of a global pest (pp. 385-421). Springer, Dordrecht.

Attia, S., Grissa, K. L., Lognay, G., Bitume, E., Hance, T., \& Mailleux, A. C. (2013). A review of the major biological approaches to control the worldwide pest Tetranychus urticae (Acari: Tetranychidae) with special reference to natural pesticides. Journal of Pest Science, 86(3), 361-386.

Aucejo, S., \& Miret, J. J. (2005). Métodos de control de la araña roja en cítricos. Vida rural, 210, 30-33.

Badawy, M. E., El-Arami, S. A., \& Abdelgaleil, S. A. (2010). Acaricidal and quantitative structure activity relationship of monoterpenes against the two-spotted spider mite, Tetranychus urticae. Experimental and Applied Acarology, 52(3), 261-274.

Badii, M. H., \& McMurtry, J. A. (1984). Feeding behavior of some phytoseiid predators on the broad mite, Polyphagotarsonemus latus [Acari: Phytoseiidae, Tarsonemidae]. Entomophaga, 29(1), 49-53.

Bandoly, M., \& Steppuhn, A. (2016). A push-button: Spodoptera exigua oviposition on Nicotiana attenuata dose-independently primes the feeding-induced plant defense. Plant Signaling \& Behavior, 11(1), e1114198.

Bañuls, J., Serna, M. D., Legaz, F., Talon, M., \& Primo-Millo, E. (1997). Growth and gas exchange parameters of Citrus plants stressed with different salts. Journal of Plant Physiology, 150(1-2), 194-199

Barreda, A., T., Catalán, J., \& Miret, J. A. J. (2011). Gestión integral de plagas en cítricos: aplicación práctica. Phytoma España: La revista profesional de sanidad vegetal, (230), 30-36. 
Beaulieu, F., \& Beard, J. J. (2018). Acarine biocontrol agents Neoseiulus californicus sensu Athias-Henriot (1977) and N. barkeri Hughes (Mesostigmata: Phytoseiidae) redescribed, their synonymies assessed, and the identity of $N$. californicus (McGregor) clarified based on examination of types. Zootaxa, 4500(4), 451-507.

Bensoussan, N., Santamaria, M. E., Zhurov, V., Diaz, I., Grbić, M., \& Grbić, V. (2016). Plant-herbivore interaction: dissection of the cellular pattern of Tetranychus urticae feeding on the host plant. Frontiers in Plant Science, 2016, 7: 1105.

Beran, F., Köllner, T. G., Gershenzon, J., \& Tholl, D. (2019). Chemical convergence between plants and insects: biosynthetic origins and functions of common secondary metabolites. New Phytologist.

Birkett, M. A., Chamberlain, K., Guerrieri, E., Pickett, J. A., Wadhams, L. J., \& Yasuda, T. (2003). Volatiles from whitefly-infested plants elicit a host-locating response in the parasitoid, Encarsia formosa. Journal of Chemical Ecology, 29(7), 1589-1600.

Bolckmans, K. J. F., \& van Houten, Y. M. (2006) Mite composition, use thereof, method for rearing a phytoseiid predatory mite, rearing system for rearing said phytoseiid predatory mite and methods for biological pest control on a crop. WO Patent $\mathrm{WO} / 2006 / 071107$.

Bouagga, S., Urbaneja, A., Rambla, J. L., Flors, V., Granell, A., Jaques, J. A., \& PérezHedo, M. (2018). Zoophytophagous mirids provide pest control by inducing direct defences, antixenosis and attraction to parasitoids in sweet pepper plants. Pest Management Science, 74(6), 1286-1296.

Bruessow, F., Asins, M. J., Jacas, J. A., \& Urbaneja, A. (2010). Replacement of CTV susceptible sour orange rootstock by CTV-tolerant ones may have triggered outbreaks of Tetranychus urticae in Spanish citrus. Agriculture, Ecosystems \& Environment, 137(1-2), 93-98.

Bruin, J., Dicke, M., \& Sabelis, M. W. (1992). Plants are better protected against spidermites after exposure to volatiles from infested conspecifics. Experientia, 48(5), 525529. 
Bruinsma, M., Van Broekhoven, S., Poelman, E. H., Posthumus, M. A., Müller, M. J., Van Loon, J. J., \& Dicke, M. (2010). Inhibition of lipoxygenase affects induction of both direct and indirect plant defences against herbivorous insects. Oecologia. 162(2), 393-404.

Cabedo-López, M., Cruz-Miralles, J., Vacas, S., Navarro-Llopis, V., Pérez-Hedo, M., Flors, V., \& Jaques, J. A. The olfactive responses of Tetranychus urticae natural enemies in citrus depend on plant genotype, prey presence, and their diet specialization. Journal of Pest Science. doi: org/10.1007/s10340-019-01107-7.

Castañé, C., Arnó, J., Gabarra, R., \& Alomar, O. (2011). Plant damage to vegetable crops by zoophytophagous mirid predators. Biological Control, 59(1), 22-29.

Coll, M., \& Guershon, M. (2002). Omnivory in terrestrial arthropods: mixing plant and prey diets. Annual review of entomology, 47(1), 267-297.

Conrath, U. (2011). Molecular aspects of defence priming. Trends in Plant Science, 16(10), 524-531.

Cook, S. M., Khan, Z. R., \& Pickett, J. A. (2007). The use of push-pull strategies in integrated pest management. Annual Review of Entomology, 52, 375-400.

Croft, B. A., Luh, H. K., \& Schausberger, P. (1999). Larval size relative to larval feeding, cannibalism of larvae, egg or adult female size and larval-adult setal patterns among 13 phytoseiid mite species. Experimental and Applied Acarology, 23(7), 599-610.

Cruz-Miralles, J., Cabedo-López, M., Pérez-Hedo, M., Flors, V., \& Jaques, J. A. (2019). Zoophytophagous mites can trigger plant-genotype specific defensive responses affecting potential prey beyond predation: the case of Euseius stipulatus and Tetranychus urticae in citrus. Pest Management Science. doi: org/10.1002/ps.5309.

De Puysseleyr, V., Höfte, M., \& De Clercq, P. (2011). Ovipositing Orius laevigatus increase tomato resistance against Frankliniella occidentalis feeding by inducing the wound response. Arthropod-Plant Interactios, 5(1), 71-80.

Di Palma, A., \& Alberti, G. (2001). Fine structure of the female genital system in phytoseiid mites with remarks on egg nutrimentary development, sperm-access system, sperm transfer, and capacitation. Experimental and Applied Acarology, 25(7), 525. 
Dicke, M. A. R. C. E. L., \& Sabelis, M. W. (1989). Does it pay plants to advertise for bodyguards. In H. Lambers, ML Cambridge, H. Konings and TL Pons (Eds), Causes and Consequences of Variation in Growth Rate and Productivity of Higher Plants, (pp. 341-358). The Hague, The Netherlands. SPB.

Dicke, M., \& van Loon, J. J. (2000). Multitrophic effects of herbivore-induced plant volatiles in an evolutionary context. Entomologia Experimentalis et Applicata, 97(3), 237-249.

Dudareva, N., Klempien, A., Muhlemann, J. K., \& Kaplan, I. (2013). Biosynthesis, function and metabolic engineering of plant volatile organic compounds. New Phytologist, 198, 16-32.

Dudareva, N., Negre, F., Nagegowda, D.A., \& Orlova, I. (2006). Plant volatiles: Recent advances and future perspectives. Critical Reviews in Plant Sciences, 25, 417-40.

Easterbrook, M. A., Fitzgerald, J. D., \& Solomon, M. G. (2001). Biological control of strawberry tarsonemid mite Phytonemus pallidus and two-spotted spider mite Tetranychus urticae on strawberry in the UK using species of Neoseiulus (Amblyseius)(Acari: Phytoseiidae). Experimental and Applied Acarology, 25(1), 2536.

Erb, M., Meldau, S., \& Howe, G. A. (2012). Role of phytohormones in insect-specific plant reactions. Trends in Plant Science, 17(5), 250-259.

Escudero, L., \& F. Ferragut. (1996). Comportamiento de Phytoseiulus persimilis AthiasHenriot y Neoseiulus californicus (McGregor) (Acari: Phytoseiidae) ante diferentes densidades de presa. Boletín de sanidad vegetal. Plagas, 22, 115-124.

Fagan, W. F. (1997). Omnivory as a stabilizing feature of natural communities. The American Naturalist, 150(5), 554-567.

Farmer, E. E., Gasperini, D., \& Acosta, I. F. (2014). The squeeze cell hypothesis for the activation of jasmonate synthesis in response to wounding. New Phytologist, 204(2), 282-288.

Ferragut, F., Costa-Comelles, J., Garcia-Marí, F, Laborda, R., Roca, D., \& Marzal, C. (1988). Dinámica poblacional del fitoseido Euseius stipulatus (Athias-Henriot) y su presa Panonychus citri (McGregor) (Acari: Phytoseiidae, Tetranychidae), en los cítricos españoles. Boletín de sanidad vegetal. Plagas, 14, 45-54. 
Freinschlag, J., \& Schausberger, P. (2016). Predation risk-mediated maternal effects in the two-spotted spider mite, Tetranychus urticae. Experimental and Applied Acarology, 69(1), 35-47.

Grafton-Cardwell, E.E., Ouyang, Y.L., \& Striggow, R.A. (1997). Predaceous mites (Acari: Phytoseiidae) for control of spider mites (Acari: Tetranychidae) in nursery citrus. Environmental Entomology, 26, 121-130.

Gregg, P. C., Del Socorro, A. P., \& Landolt, P. J. (2018). Advances in attract-and-kill for agricultural pests: beyond pheromones. Annual Review of Entomology, 63, 453-70.

Grout, T. G. (1994). The distribution and abundance of phytoseiid mites (Acari: Phytoseiidae) on citrus in southern Africa and their possible value as predators of citrus thrips (Thysanoptera: Thripidae). Experimental and Applied Acarology, 18(2), 61-71.

Guzmán, C., Sahún, M.R., \& Montserrat, M. (2016). Intraguild predation between phytoseiid mite species might not be so common. Experimental and Applied Acarology, 68, 441-453.

Heil, M. (2008). Indirect defence via tritrophic interactions. New Phytologist, 178, 4161.

Heil, M., Koch, T., Hilpert, A., Fiala, B., Boland, W., \& Linsenmair, K. E. (2001). Extrafloral nectar production of the ant-associated plant, Macaranga tanarius, is an induced, indirect, defensive response elicited by jasmonic acid. Proceedings of the National Academy of Sciences, 98(3), 1083-1088.

Helle, W., \& Sabelis, M. W. (1985). Spider mites, their biology, natural enemies. Control, 1, 406.

Helms, A. M., Ray, S., Matulis, N. L., Kuzemchak, M. C., Grisales, W., Tooker, J. F., \& Ali, J. G. (2019). Chemical cues linked to risk: Cues from below-ground natural enemies enhance plant defences and influence herbivore behaviour and performance. Functional Ecology.

Hilker, M., \& Fatouros, N.E. (2015). Plant responses to insect egg deposition. Annual Review of Entomology, 60, 493-515.

Hilker, M., \& Meiners, T. (2010). How do plants "notice" attack by herbivorous arthropods? Biological Reviews, 85(2), 267-280. 
Howe, G. A. \& Jander, G. (2008). Plant immunity to insect herbivores. Annual Review of Plant Biology, 59, 41-66.

Jacas, J. A., \& Urbaneja, A. (2010). Biological control in citrus in Spain: from classical to conservation biological control. In Ciancino, A., \& Mukerji, K.G., (Eds.), Integrated management of arthropod pests and insect borne diseases. Vol. 5 (pp. 61-72). Springer. Dordrecht.

Jaques, J. A., Aguilar-Fenollosa, E., Hurtado-Ruiz, M. A., \& Pina, T. (2015). Food web engineering to enhance biological control of Tetranychus urticae by phytoseiid mites (Tetranychidae: Phytoseiidae) in Citrus. In Prospects for Biological Control of Plant Feeding Mites and Other Harmful Organisms (pp. 251-269). Springer, Cham.

Kant, M. R., Ament, K., Sabelis, M. W., Haring, M. A., \& Schuurink, R. C. (2004). Differential timing of spider mite-induced direct and indirect defenses in tomato plants. Plant Physiology, 135(1), 483-495.

Kant, M. R., Jonckheere, W., Knegt, B., Lemos, F., Liu, J., Schimmel, B. C. J., ... \& Egas, M. (2015). Mechanisms and ecological consequences of plant defence induction and suppression in herbivore communities. Annals of Botany, 115(7), 1015-1051.

Karban, R., \& Baldwin, I. T. (1997). Induced Responses to Herbivory-University of Chicago Press. Chicago. Illinois. USA.

Kuwahara, Y. (2004). Chemical ecology of astigmatid mites. In Cardé R.T. \& Millar J.G. (Eds), Advances in Insect Chemical Ecology (pp. 76-109). Cambridge University Press, Cambridge.

Lalonde, R. G., McGregor, R. R., Gillespie, D. R., \& Roitberg, B. D. (1999). Plantfeeding by arthropod predators contributes to the stability of predator-prey population dynamics. Oikos, 87(3), 603-608.

Lu, Y., Wu, K., Jiang, Y., Guo, Y., \& Desneux, N. (2012). Widespread adoption of Bt cotton and insecticide decrease promotes biocontrol services. Nature, 487(7407), 362.

Magalhães, S., \& Bakker, F.M. (2002). Plant feeding by a predatory mite inhabiting cassava. Experimental and Applied Acarology, 27: 27-37.

Martínez-Ferrer, M. T., Jacas, J. A., Ripollés-Moles, J. L., \& Aucejo-Romero, S. (2006). Approaches for sampling the twospotted spider mite (Acari: Tetranychidae) on clementines in Spain. Journal of Economic Entomology, 99(4), 1490-1499. 
McMurtry, J. A., \& Croft, B. A. (1997). Life-styles of phytoseiid mites and their roles in biological control. Annual Review of Entomology, 42(1), 291-321.

McMurtry, J. A., Badii, M. H., \& Congdon, B. D. (1985). Studies on a Euseius species complex on avocado in Mexico and Central America, with a description of a new species (Acari: Phytoseiidae). Acarologia.

McMurtry, J. A., De Moraes, G. J. D., \& Sourassou, N. F. (2013). Revision of the lifestyles of phytoseiid mites (Acari: Phytoseiidae) and implications for biological control strategies. Systematic and Applied Acarology, 18(4):297-321.

McMurtry, J.A. (1977). Some predaceous mites (Phytoseiidae) on citrus in the Mediterranean region. Entomophaga, 22, 19-60.

Messelink, G. J., Bloemhard, C. M. J., Hoogerbrugge, H., Van Schelt, J., Ingegno, B. L., \& Tavella, L. (2015). Evaluation of mirid predatory bugs and release strategy for aphid control in sweet pepper. Journal of Applied Entomology, 139(5), 333-341.

Messelink, G. J., Sabelis, M. W., \& Janssen, A. (2012). Generalist predators, food web complexities and biological pest control in greenhouse crops. In Integrated Pest Management and Pest Control-Current and Future Tactics. IntechOpen.

Morgan, E.D. (2010). Biosynthesis in Insects. Advanced Edition. The Royal Society of Chemistry Publishing (pp. 344). Cambridge. UK.

Müller, C., \& Riederer, M. (2005). Plant surface properties in chemical ecology. Journal of Chemical Ecology, 31(11), 2621-2651.

Naselli, M., Urbaneja, A., Siscaro, G., Jaques, J. A., Zappalà, L., Flors, V., \& PérezHedo, M. (2016). Stage-related defense response induction in tomato plants by Nesidiocoris tenuis. International Journal of Molecular Sciences, 17(8), 1210.

Nomikou, M., Janssen, A., \& Sabelis, M.W. (2003). Phytoseiid predator of whitefly feeds on plant tissue. Experimental and Applied Acarology, 31, 27-36.

Okassa, M., Tixier, M. S., \& Kreiter, S. (2010). Morphological and molecular diagnostics of Phytoseiulus persimilis and Phytoseiulus macropilis (Acari: Phytoseiidae Experimental and Applied Acarology, 52(3), 291-303.

Opitz, S.E.W., and Müller, C. (2009). Plant chemistry and insect sequestration. Chemoecology. 19, 117-154. 
Pappas, M. L., Steppuhn, A., Geuss, D., Topalidou, N., Zografou, A., Sabelis, M. W., \& Broufas, G. D. (2015). Beyond predation: the zoophytophagous predator Macrolophus pygmaeus induces tomato resistance against spider mites. Plos One. 10(5), e0127251.

Pascual-Ruiz, S., Aguilar-Fenollosa, E., Ibáñez-Gual, V., Hurtado-Ruiz, M. A., Martínez-Ferrer, M. T., \& Jacas, J. A. (2014). Economic threshold for Tetranychus urticae (Acari: Tetranychidae) in clementine mandarins Citrus clementina. Experimental and Applied Acarology, 62(3), 337-362.

Pastor, V., Balmer, A., Gamir, J., Flors, V., \& Mauch-Mani, B. (2014). Preparing to fight back: generation and storage of priming compounds. Frontiers in Plant Science, 5, 295.

Perdikis, D., Fantinou, A., \& Lykouressis, D. (2011). Enhancing pest control in annual crops by conservation of predatory Heteroptera. Biological Control, 59(1), 13-21.

Pérez-Hedo, M., Bouagga, S., Jaques, J. A., Flors, V., \& Urbaneja, A. (2015). Tomato plant responses to feeding behavior of three zoophytophagous predators (Hemiptera: Miridae). Biological Control, 86, 46-51.

Pérez-Sayas, C., Pina, T., Gómez-Martínez, M. A., Camañes, G., Ibáñez-Gual, M. V., Jaques, J. A., \& Hurtado, M. A. (2015). Disentangling mite predator-prey relationships by multiplex PCR. Molecular Ecology Resources, 15(6), 1330-1345.

Pieterse, C. M. J., Leon-Reyes, A., Van der Ent, S., \& Van Wees, S. C. (2009). Networking by small-molecule hormones in plant immunity. Nature Chemical Biology, 5, 308-316.

Pieterse, C. M., Van der Does, D., Zamioudis, C., Leon-Reyes, A., \& Van Wees, S. C. (2012). Hormonal modulation of plant immunity. Annual Review of Cell and Developmental Biology, 28, 489-521.

Pimm, S. L., \& Lawton, J. H. (1978). On feeding on more than one trophic level. Nature. 275(5680), 542.

Pina, T., Argolo, P. S., Urbaneja, A., \& Jacas, J. A. (2012). Effect of pollen quality on the efficacy of two different life-style predatory mites against Tetranychus urticae in citrus. Biological Control, 61(2), 176-183. 
Porres, M. A., McMurtry, J. A., \& March, R. B. (1975). Investigations of leaf sap feeding by three species of phytoseiid mites by labelling with radioactive phosphoric acid (H3 32PO4). Annals of the Entomological Society of America, 68(5), 871-872.

Robert-Seilaniantz, A., Grant, M., \& Jones, J. D. (2011). Hormone crosstalk in plant disease and defense: more than just jasmonate-salicylate antagonism. Annual Review of Phytopathology, 49, 317-343.

Rodriguez-Saona, C. R., Musser, R. O., Vogel, H., Hum-Musser, S. M., \& Thaler, J. S. (2010). Molecular, biochemical, and organismal analyses of tomato plants simultaneously attacked by herbivores from two feeding guilds. Journal of Chemical Ecology, 36(10), 1043-1057.

Sabelis, M. W., \& Bakker, F. M. (1992). How predatory mites cope with the web of their tetranychid prey: a functional view on dorsal chaetotaxy in the Phytoseiidae. Experimental and Applied Acarology, 16(3), 203-225.

Sabelis, M. W., \& Janssen, A. (1994). Evolution of life-history patterns in the Phytoseiidae. In Mites (pp. 70-98). Springer. Boston. MA.

Sabelis, M. W., Janssen, A., \& Kant, M. R. (2001). The enemy of my enemy is my ally. Science, 291(5511), 2104-2105.

Sabelis, M. W., Janssen, A., Bruin, J., Bakker, F. M., Drukker, B., Scutareanu, P., \& van Rijn, P. C. (1999). Interactions between arthropod predators and plants: a conspiracy against herbivorous arthropods? In Ecology and Evolution of the Acari (pp. 207-229). Springer. Dordrecht.

Schausberger, P., \& Croft, B.A. (2000). Nutritional benefits of intraguild predation and cannibalism among generalist and specialist phytoseiid mites. Ecological Entomology, $25,473-480$.

Schmidt, R. A. (2014). Leaf structures affect predatory mites (Acari: Phytoseiidae) and biological control: a review. Experimental and Applied Acarology, 62, 1-17.

Schuman, M. C., \& Baldwin, I. T. (2016). The layers of plant responses to insect herbivores. Annual Review of Entomology, 61, 373-394.

Schwartzberg, E.G., \& Tumlinson, J. H. (2014). Aphid honeydew alters plant defence responses. Functional Ecology, 28, 386-394. 
Tanaka, T., Ikeda, A., Shiojiri, K., Ozawa, R., Shiki, K., Nagai-Kunihiro, N., Fujita, K., Sugimoto, K., Yamato, K. T., Dohra, H., Ohnishi, T., Koeduka, T., \& Matsui, K. (2018). Identification of a Hexenal Reductase That Modulates the Composition of Green Leaf Volatiles. Plant Physiology, 178, 552-564.

Tanigoshi, L.K., Bahdousheh, M., Babcock, J.M., \& Sawaqed, R. (1990). Euseius scutalis (Athias-Henriot) a predator of Eutetranychus orientalis (Klein) in Jordan: toxicity of some acaricides to E. orientalis. Arab Journal of Plant Protection, 8, 114 120.

Turlings, T. C., Lengwiler, U. B., Bernasconi, M. L., \& Wechsler, D. (1998). Timing of induced volatile emissions in maize seedlings. Planta, 207(1), 146-152.

Turlings, T.C.J., \& Ton, J. (2006). Exploiting scents of distress: the prospect of manipulating herbivore-induced plant odours to enhance the control of agricultural pests. Current Opinion in Plant Biology, 9, 421-427.

Urbaneja A., \& Jacas J. A. (2008). Tipos de control biológico y métodos para su implantación. In Jacas, J. A., and Urbaneja, A. (Eds.), Control biológico de plagas agrícolas (pp. 151-164). Phytoma.

Urbaneja, A., Pascual-Ruiz, S., Pina, T., Abad-Moyano, R., Vanaclocha, P., Montón, H., ... \& Jacas, J. A. (2008). Efficacy of five selected acaricides against Tetranychus urticae (Acari: Tetranychidae) and their side effects on relevant natural enemies occurring in citrus orchards. Pest Management Science: Formerly Pesticide Science, 64(8), 834-842.

Urbaneja-Bernat, P., Ibáñez-Gual, V., Montserrat, M., Aguilar-Fenollosa, E., \& Jaques, J. A. (2019). Can interactions among predators alter the natural regulation of an herbivore in a climate change scenario? The case of Tetranychus urticae and its predators in citrus. Journal of Pest Science. doi: org/10.1007/s10340-019-01114-8.

Van Den Boom, C. E., Van Beek, T. A., Posthumus, M. A., De Groot, A., \& Dicke, M. (2004). Qualitative and quantitative variation among volatile profiles induced by Tetranychus urticae feeding on plants from various families. Journal of Chemical Ecology, 30 (1), 69-89.

Van der Meijden, E., \& Klinkhamer, P. G. L. (2000). Conflicting interests of plants and the natural enemies of herbivores. Oikos 89, 202-8. 
Van Leeuwen, T., Vanholme, B., Van Pottelberge, S., Van Nieuwenhuyse, P., Nauen, R., Tirry, L., \& Denholm, I. (2008). Mitochondrial heteroplasmy and the evolution of insecticide resistance: non-Mendelian inheritance in action. Proceedings of the National Academy of Sciences, 105(16), 5980-5985.

Van Lenteren, J. C. (2012). The state of commercial augmentative biological control: plenty of natural enemies, but a frustrating lack of uptake. Biological Control, 57(1), $1-20$.

Van Lenteren, J. C., Bolckmans, K., Köhl, J., Ravensberg, W. J., \& Urbaneja, A. (2018). Biological control using invertebrates and microorganisms: plenty of new opportunities. Biological Control, 63(1), 39-59.

Vela, J. M., Wong, E., Jaques, J. A., Ledesma, C., \& Boyero, J. R. (2017). Mite diversity (Acari: Tetranychidae, Tydeidae, Iolinidae, Phytoseiidae) and within-tree distribution in citrus orchards in southern Spain, with special reference to Eutetranychus orientalis. Experimental and Applied Acarology, 73(2), 191-207.

Wäckers, F. L. (2001). A comparison of nectar-and honeydew sugars with respect to their utilization by the hymenopteran parasitoid Cotesia glomerata. Journal of Insect Physiology, 47(9), 1077-1084.

Wallis, C., Eyles, A., Chorbadjian, R., Gardener, B. M., Hansen, R., Cipollini, D., ... \& Bonello, P. (2008). Systemic induction of phloem secondary metabolism and its relationship to resistance to a canker pathogen in Austrian pine. New Phytologist, 177(3), 767-778.

Walter, D. E. (1996). Living on leaves: mites, tomenta, and leaf domatia. Annual Review of Entomology, 41(1), 101-114.

Wei, J., \& Kang, L. (2011). Roles of (Z)-3-hexenol in plant-insect interactions. Plant Signaling and Behavoir, 6(3), 369-371.

Wijnands, F. G., \& Kroonen-Backbier, B. M. A. (1993). Management of farming systems to reduce pesticide inputs: the integrated approach. Crop Protection: Developments and Perspectives. 227-234.

Wu, J., \& Baldwin, I. T. (2010). New Insights into plant responses to the attack from insect herbivores. Annual Review of Genetics, 44,1-24. 
Zhang, N. X., Messelink, G. J., Alba, J. M., Schuurink, R. C., Kant, M. R., \& Janssen, A. (2018). Phytophagy of omnivorous predator Macrolophus pygmaeus affects performance of herbivores through induced plant defences. Oecologia, 186(1), 101113.

Zhang, Z. Q., \& Croft, B. A. (1995). Interspecific competition and predation between immature Amblyseius fallacis, Amblyseius andersoni, Typhlodromus occidentalis and Typhlodromus pyri (Acari: Phytoseiidae). Experimental and Applied Acarology, 19(5), 247-257. 


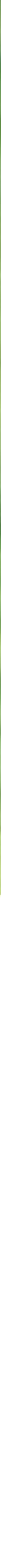